\title{
STREAMBANK STABILIZATION DESIGN, RESEARCH, AND MONITORING: THE CURRENT STATE AND FUTURE NEEDS
}

\author{
K. A. Bigham
}

\section{HighLIGHTS}

- Eleven general streambank stabilization (SBS) techniques have been used worldwide.

- Rules-of-thumb and practitioner experience are still heavily applied in SBS design.

- Research needs include assessing the spatiotemporal variability of SBS and improving numerical simulation.

- Future SBS experiments need to include design details with results that can be easily communicated to designers.

ABSTRACT. Streambank stabilization techniques, designed to maximize localized streambank shear strength and/or minimize the forces acting on a streambank, have been in existence for centuries and are still a popular river management technique used by practitioners worldwide. The purpose of this literature review is to identify common streambank stabilization techniques, compile and summarize the recent peer-reviewed journal articles on these techniques, and determine research needs. Eleven general streambank stabilization practices, consisting of both instream structures and streambank management techniques, are identified in this literature review. Over 140 peer-reviewed journal articles on these techniques have been published over the last 20 years. To improve design and implementation of streambank stabilization techniques, two major research needs were identified: (1) further assess and quantify the spatiotemporal effects that streambank stabilization practices have on bank erosion, hydraulics, sediment transport, and habitat and (2) continue to improve numerical models for streambank stabilization design in order to holistically evaluate and address these effects. In addition, a list of specific research needs for each stabilization technique is provided. To help address these research needs, it is recommended that future streambank stabilization publications should (1) use consistent technique nomenclature, (2) provide characteristic details about the techniques and channels studied, (3) justify the experimental setup, and (4) explain how the research will improve streambank stabilization design.

Keywords. Bankfull bench, Barb, Bioengineering, Deflector, Dike, Dyke, Groin, Groyne, Jetty, Large woody debris, LPSTP, Retarder, Revetment, Riprap bank, River training, Shaping, Spur, Stream restoration, Streambank erosion, Streambank stabilization, Toe rock, Toe wood, Vane, Weir.

I n many streams across the globe, excess sediment and sorbed pollutants (e.g., phosphorus, pesticides, pathogens, etc.) are a leading water quality impairment, threatening water supply availability, aquatic ecosystem biodiversity, and the benefits that these ecosystems may provide (Vörösmarty et al., 2010; Walling and Fang, 2003). While sediment can originate from a variety of sources including rill, gully, or channel erosion, the main source in many impaired streams is channel erosion and primarily

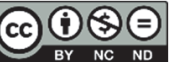

The authors have paid for open access for this article. This work is licensed under a Creative Commons AttributionNonCommercial-NoDerivatives 4.0 International License https://creative commons.org/licenses/by-nc-nd/4.0/

Submitted for review in August 2019 as manuscript number NRES 13647; approved for publication as a Review Article by the Natural Resources \& Environmental Systems Community of ASABE in December 2019.

The author is Kari A. Bigham, Instructor, Department of Biological and Agricultural Engineering, 1016 Seaton Hall, Kansas State University, Manhattan, KS 66506; phone: 785-532-2788; e-mail: kabigham@ksu.edu. streambank erosion (Belmont et al., 2011; Gellis and Sanisaca, 2018; Hassan et al., 2017; Juracek and Ziegler, 2009; Trimble, 1997).

Over the years, streambank erosion has developed a reputation as a process that needs to be halted, as it often puts valuable infrastructure and land at risk. However, from a geomorphic and ecological viewpoint, this belief is not always valid. Streambank erosion is a natural and necessary geomorphic process that dissipates flow energy and introduces both sediment and organic debris that are essential for the creation, maintenance, and diversification of aquatic habitat (Florsheim et al., 2008). Rates of streambank erosion depend on streambank shear strength and the gravitational and hydraulic forces that act on it (Simon et al., 2000). These dominant drivers are influenced by the streambank's sediment composition, pore-water pressure, bank geometry (Simon et al., 2000), vegetation type and density (Pollen, 2007), and location along the stream (Parker et al., 2008), as well as the stream's morphology (Papanicolaou et al., 2007), water stage, flow regime, slope (Simon et al., 2000), chemical 
properties (Hoomehr et al., 2018), climate (Couper and Maddock, 2001), and channel evolution phase (Simon and Hupp, 1986). With these in mind, streambanks can erode in three general ways: via subaerial weakening and weathering, fluvial erosion, and/or mass wasting due to geotechnical failure. Furthermore, dominant streambank erosion processes and rates often vary through space and time, as boundary conditions change and forces shift (Couper, 2004).

Disturbance within a drainage area can cause channel instability through bed degradation and/or aggradation and, as a result, accelerate streambank erosion. Channel instability continues, with the channel cycling through a number of evolutionary phases, until a dynamic equilibrium is reached (Simon and Hupp, 1986). The process of channel evolution could take decades to centuries to achieve, depending on stream and watershed characteristics (Simon and Rinaldi, 2000). Channel instability and accelerated streambank erosion are deleterious; they increase sediment and nutrient loading downstream (Walling and Fang, 2003), lead to biological impairment (Vörösmarty et al., 2010), and may also have adverse effects on infrastructure and land (Fox et al., 2016; Morris et al., 1996). Both natural and anthropogenic influences can cause stream instability. Natural influences generally occur over a geological timescale and include changes in climate, vegetation, topography, and sediment source. Alternatively, anthropogenic influences can have an almost immediate effect on channel stability. Examples of anthropogenic influences include channelization, construction of dams and levees, deforestation, dredging, human-induced climate change, urbanization, and conversion of land for agricultural purposes (Goudie, 2006; Kondolf, 1997; Simon and Rinaldi, 2000; Trimble, 1997).

In an attempt to mitigate the impacts of channel instability and/or protect infrastructure and land, scientists and practitioners have developed river management techniques with the intent of reducing streambank erosion, and in some cases, expediting the channel evolution process. One approach is to implement reach-scale to river-scale stream restoration on unstable systems. Stream restoration is often defined as the design and construction of a vertically and laterally stable, floodplain-connected channel that is capable of carrying the bankfull or effective discharge, which typically occurs within a one-year to two-year return interval, and its produced sediment load (Rosgen, 1996; Shields et al., 2003a). Rather than "fixing" or "training" a stream, restoration efforts assist in the improvement of physical and/or biological processes that may have been compromised due to disturbance (Wohl et al., 2005). For example, by reconnecting the stream to a low-lying floodplain, both flow energy dissipation and habitat heterogeneity can be improved, making the stream more physically and biologically resilient to major flooding events (Palmer et al., 2005; Rosgen, 1996). However, prior to implementing restoration efforts on the reach to river scale, Wohl et al. (2005) noted the importance of first addressing the watershed-scale issues that may have caused channel instability and ecosystem degradation to occur in the first place. Due to the scale of these projects, stream restoration can be difficult to promote and imple- ment, as projects tend to be expensive (Moerke and Lamberti, 2004) and may require cooperation from several landowners.

An alternative to stream restoration is streambank stabilization. Streambank stabilization is defined as a single technique or system of techniques that maximize localized streambank shear strength and/or minimize the forces acting on a streambank with the intent of halting or minimizing lateral retreat. Streambank stabilization systems are the oldest (Evette et al., 2009; Uijttewaal, 2005) and arguably the most popular river management technique used by practitioners. Streambank stabilization systems can be a component of a stream restoration plan, but they are often developed on a site-by-site basis due to the societal need to protect local infrastructure or land. When implemented in this manner, critics have referred to these systems as a "one size fits all" (Rosgen, 1996) or "Band-Aid" (Bernard and Tuttle, 1998) approach to restoration, as they may not address the underlying cause of instability and/or may result in instability at the stabilized site and elsewhere (Florsheim et al., 2008; Rosgen, 1996; Wohl et al., 2005).

Streambank stabilization systems typically consist of (1) hard engineering techniques, (2) plant-based bioengineering techniques, or (3) a combination, often with the intent of halting streambank erosion. Hard engineering approaches incorporate rock riprap, recycled construction material, concrete, steel pilings, sand bags, gabion baskets, or other inorganic material to build structures and/or harden streambanks. Bioengineering solutions employ organic material, living or non-living, such as wood, plants, and live cuttings, to provide roughness and add tensile strength.

The design and implementation of streambank stabilization systems began as early as the first century $\mathrm{CE}$, when bioengineering approaches were described by Columella, an authority on agriculture in the Roman Empire (Evette et al., 2009). Hard engineering and river training approaches were developed several centuries later and have been described and installed since at least the 16th century in Europe (Uijttewaal, 2005) and, on a much larger scale, since the end of the 19th century in both the U.S. and Europe (Evette et al., 2009; Thompson and Stull, 2002). However, over the last three decades, bioengineering techniques have regained interest, as awareness of the need to protect and maintain ecosystems has increased (Evette et al., 2009). Even though many streambank stabilization techniques have been around for centuries, the success of different techniques varies widely (Miller and Kochel, 2010, 2013) and depends largely on the location and conditions of the site, as well as the experience (Abad et al., 2008; Minor et al., 2007) and, frankly, opinion of the designer (Rosgen, 2008; Simon et al., 2007).

Given the popularity of streambank stabilization systems as well as the concerns regarding their use, this article focuses on streambank stabilization, providing a summary of the techniques as well as an in-depth review of the research and/or monitoring that has been implemented to assess the physical and biological effects of these systems. Based on this comprehensive review of streambank stabilization systems, a list of future research needs is also presented. 


\section{METHODS}

\section{IDENTIFICATION OF STREAMBANK \\ STABILIZATION TECHNIQUES}

Streambank stabilization techniques were identified by (1) including practices that the author has designed, monitored, and/or learned about in the past, (2) reviewing various streambank stabilization and stream restoration design manuals, and (3) searching both academic literature databases and the internet for keywords such as streambank stabilization, streambank erosion mitigation, and stream restoration. Based on this review, it was concluded that there are two types of streambank stabilization approaches: (1) instream structures and (2) streambank management techniques. Streambank stabilization techniques can be further divided by their intended function. There are four general functions of streambank stabilization techniques: (1) shear strength addition, (2) gravitational force reduction, (3) hydraulic force reduction, and/or (4) habitat improvement. Shear strength addition includes increasing the strength of a streambank by physically altering the bank material composition and/or adding vegetation roots. Gravitational force reduction involves removing and/or counteracting the streambank's weight. Deflecting and/or dissipating flow energy in the eroding bank region reduces the applied hydraulic force. Finally, improving aquatic and riparian habitat can be achieved by increasing habitat heterogeneity and/or providing cover.

Although the name and design specifications associated with specific streambank stabilization techniques have varied over time and among practitioners, eleven general categories of techniques were identified through this process (table 1). Example images of all of these techniques (except for a hardened streambank) are provided in figure 1. Table 1 also provides the intended function of each streambank stabilization technique. Definitions and alternate names for these techniques are provided in the "Recent Research and Monitoring of Streambank Stabilization" section of this article.

Although stabilization of an incising streambed by installing grade control structures is considered an essential prerequisite to streambank stabilization to reduce chance of system failure (Enlow et al., 2018; Shields et al., 2004; NRCS, 1996), streambed stabilization techniques are not reviewed in this article. For more information about grade control structures, see Radspinner et al. (2010).

\section{GUIDELINES FOR STREAMBANK STABILIZATION \\ LITERATURE REVIEW}

Streambank stabilization research and monitoring efforts have been disseminated through reports, textbooks, magazines, dissertations, etc., but in an effort to refine the reported results, only peer-reviewed publications published in the last 20 years and written or translated in English are summarized and discussed in this review article. Although a significant effort was put forth in gathering all publications regarding the aforementioned streambank stabilization techniques, some publications may have been missed. This review article focuses on the physical (hydraulics, bank erosion, and sediment transport) and biological effects of streambank stabilization systems, as assessed through physical models, numerical models, and field studies.

\section{RECENT RESEARCH AND MONITORING OF STREAMBANK STABILIZATION}

Overall, 146 peer-reviewed publications on streambank stabilization systems were found. Tables A1 through A17 in the Appendix provide each publication's research objectives, spatiotemporal scale, experimental design, and key findings, sorted by streambank stabilization technique. Figure 2 shows the cumulative number of publications from 1998 to 2019 for each identified streambank stabilization technique. Definitions of these techniques are provided in later sections.

Based on figure 2, bendway weirs, impermeable spurs, and rock vanes are the most commonly evaluated streambank stabilization techniques. Publication rates for studies of bendway weirs, rock vanes, and hardened streambank management techniques (i.e., retaining wall, riprap bank) have increased over the last ten years, while the literature on impermeable spurs has plateaued. Furthermore, the literature on soft streambank management techniques (i.e., vegetation, toe rock, bank shaping, etc.) has stayed steady over this time period at a rate of about one publication per year. Submerged vanes and permeable spurs are the least studied techniques, with a rate of one publication every two to three years, suggesting that these techniques are not as common as the others.

Of the research found on streambank stabilization, $80 \%$ of the studies evaluated instream structures, while only $29 \%$ evaluated streambank management techniques. There were three main study types: physical modeling, field studies, and

Table 1. General streambank stabilization techniques and their intended function (names and specifications of each technique may vary).

\begin{tabular}{|c|c|c|c|c|c|c|c|c|c|c|c|}
\hline \multirow[b]{4}{*}{$\begin{array}{l}\text { Intended } \\
\text { Function }\end{array}$} & \multicolumn{11}{|c|}{ Streambank Stabilization Techniques } \\
\hline & \multirow{2}{*}{\multicolumn{5}{|c|}{ Instream Structures }} & \multirow[b]{3}{*}{$\begin{array}{c}\text { Woody } \\
\text { Revetments }\end{array}$} & \multicolumn{5}{|c|}{ Streambank Management Techniques } \\
\hline & & & & & & & \multicolumn{4}{|c|}{ Soft } & \multirow{2}{*}{$\begin{array}{c}\text { Hard } \\
\text { Hardened } \\
\text { Bank }\end{array}$} \\
\hline & $\begin{array}{l}\text { Impermeable } \\
\text { Spurs }\end{array}$ & $\begin{array}{l}\text { Bendway } \\
\text { Weirs }\end{array}$ & Rocks & $\begin{array}{c}\text { Permeable } \\
\text { Spurs }\end{array}$ & $\begin{array}{c}\text { Submerged } \\
\text { Vanes }\end{array}$ & & $\begin{array}{l}\text { Toe } \\
\text { Rock }\end{array}$ & $\begin{array}{c}\text { Bank } \\
\text { Shaping }\end{array}$ & $\begin{array}{l}\text { Bankfull } \\
\text { Bench }\end{array}$ & Bioeng. ${ }^{[a]}$ & \\
\hline $\begin{array}{c}\text { Shear strength } \\
\text { addition }\end{array}$ & $x_{2}$ & 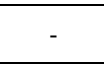 & - & $T_{2}$ & 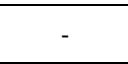 & $X^{[b]}$ & $\mathrm{X}$ & - & 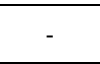 & $\mathrm{X}$ & $\mathrm{X}$ \\
\hline $\begin{array}{c}\text { Gravitational force } \\
\text { reduction }\end{array}$ & - & - & - & - & - & - & $\mathrm{X}$ & $\mathrm{X}$ & $\mathrm{X}$ & - & $\mathrm{X}$ \\
\hline $\begin{array}{l}\text { Hydraulic force } \\
\text { reduction }\end{array}$ & $\mathrm{X}$ & $\mathrm{X}$ & $\mathrm{X}$ & $\mathrm{X}$ & $\mathrm{X}$ & $\mathrm{X}$ & - & - & $\mathrm{X}$ & $\mathrm{X}$ & - \\
\hline $\begin{array}{c}\text { Habitat } \\
\text { improvement }\end{array}$ & $\mathrm{X}$ & $\mathrm{X}$ & $\mathrm{X}$ & - & - & $\mathrm{X}$ & - & - & $\mathrm{X}$ & $\mathrm{X}$ & - \\
\hline
\end{tabular}

[a] Bioengineering: includes all forms of bioengineering streambank management techniques, such as vegetative plantings, live stakes, etc.;

[b] Only woody revetments placed along the streambank toe (also known as toe wood). 


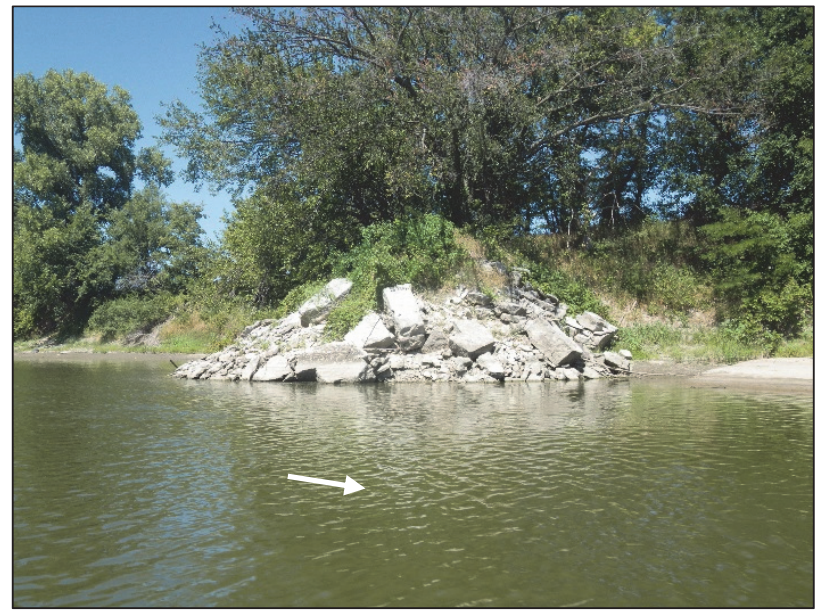

(a)

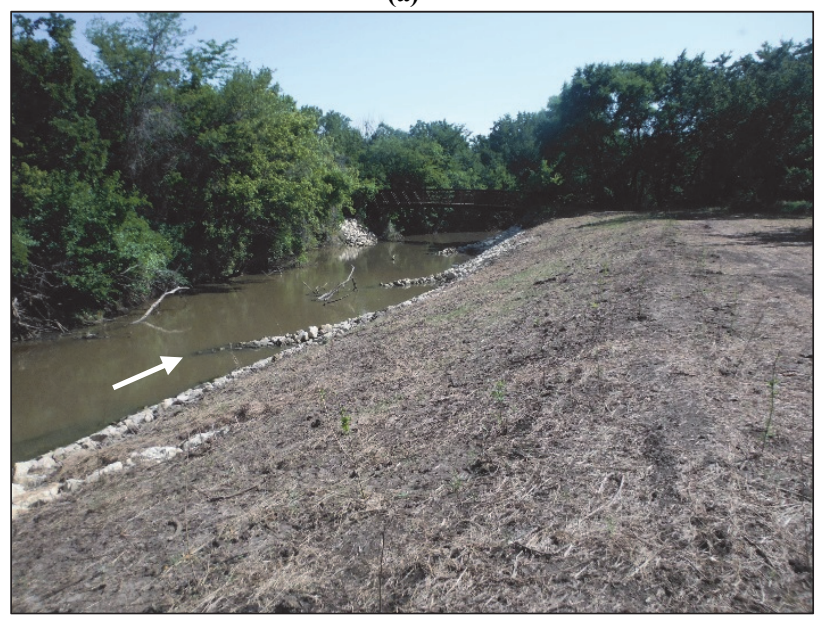

(c)

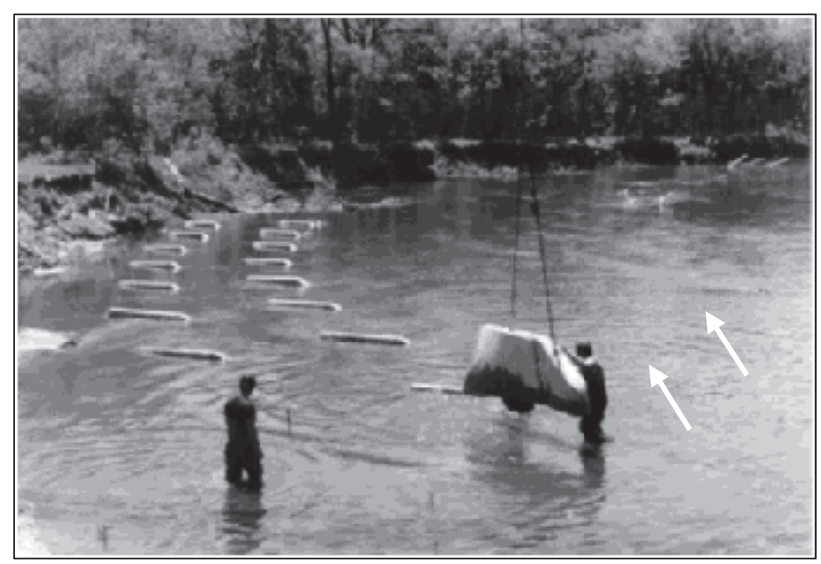

(e)

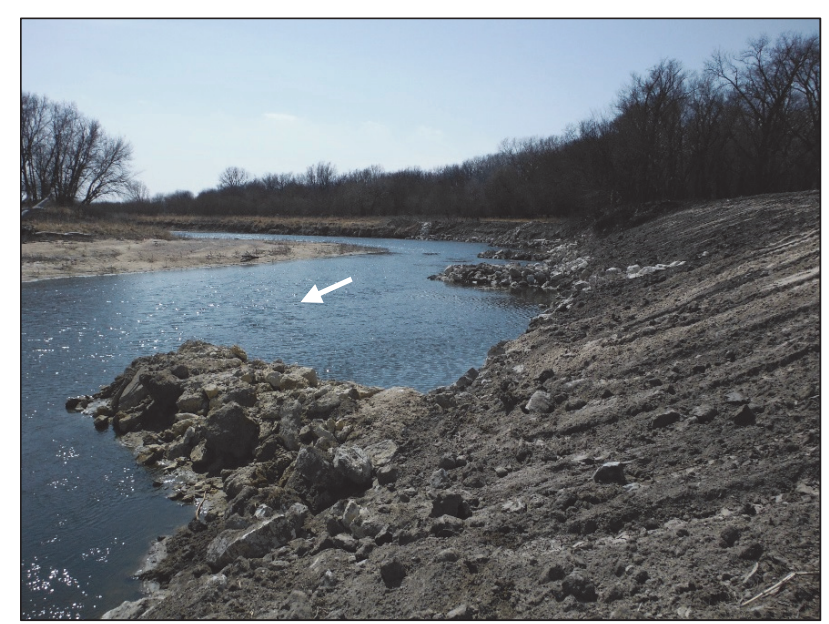

(b)

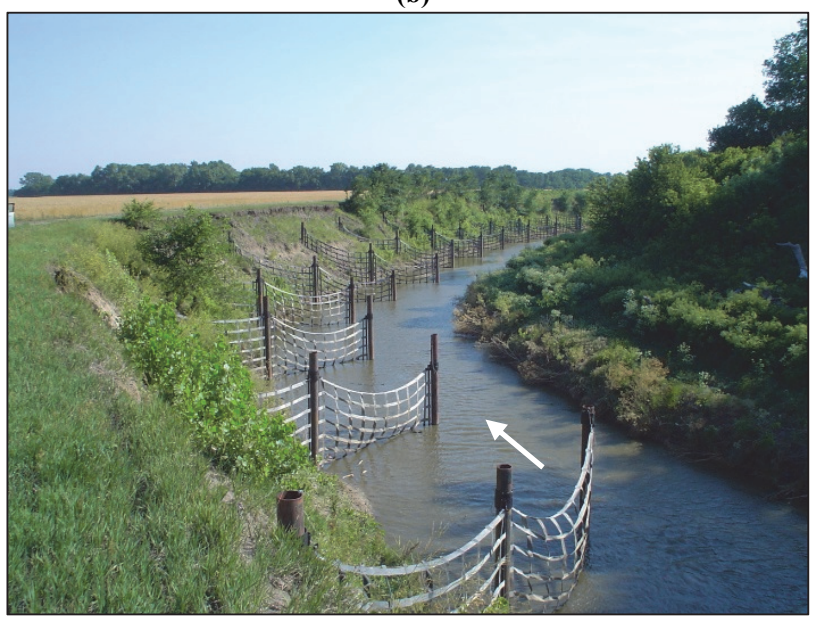

(d)

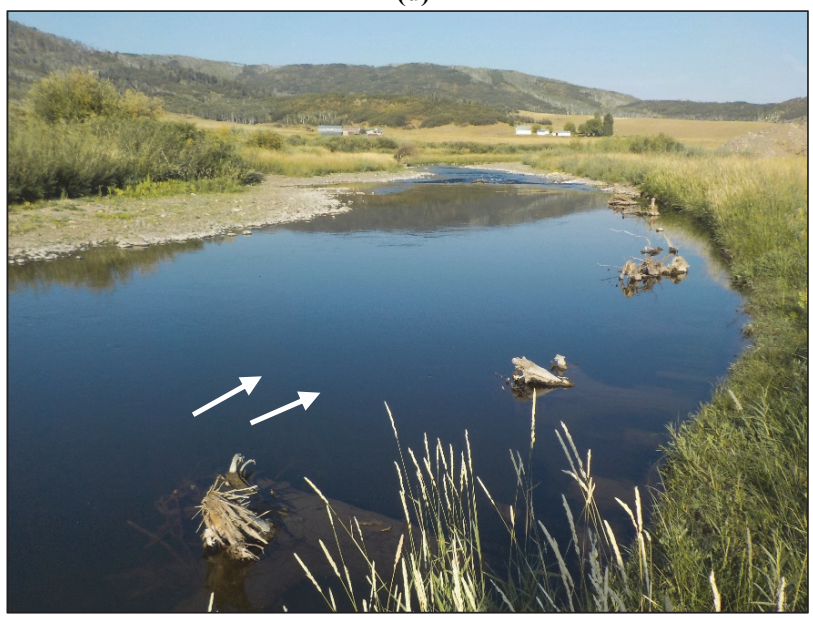

(f)

Figure 1. Examples of streambank stabilization techniques (white arrows indicate flow direction): (a) impermeable spur on Kansas River, Kansas, (b) bendway weirs, toe rock, and streambank shaping on Big Blue River, Kansas, (c) rock vanes, toe rock, and streambank shaping on Cowskin Creek, Kansas, (d) permeable spurs on Solomon River, Kansas (photo courtesy of Wildhorse Riverworks, Inc.), (e) concrete submerged vanes (photo from Iowa DNR, 2006), and (f) woody revetment/toe wood, bankfull bench, and planted vegetation on Yampa River, Colorado.

numerical modeling. Physical modeling studies were the most popular (41\%), followed by field studies (32\%), and numerical modeling studies (28\%), as shown in figure 3 . However, the majority of the instream structures studies used a physical model, while streambank management techniques were primarily assessed in the field (fig. 4). Since 2004, researchers have been working to improve numerical modeling of streambank stabilization techniques (fig. 3) using results from both physical modeling and field monitoring. Ideally, application of numerical models that are capable of simulating all physical processes would replace and/or enhance "rules of thumb" and assist designers in developing effective designs with minimal unintended impacts (Khosronejad et al., 2017). 


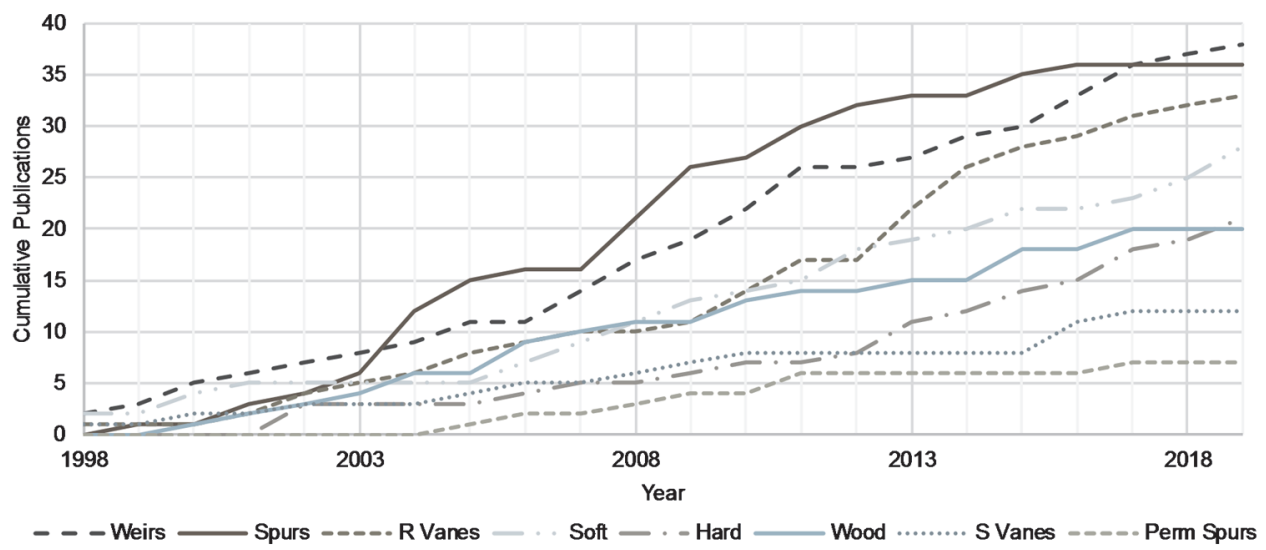

Figure 2. Cumulative number of publications (1998-2019) by streambank stabilization technique: Weirs = bendway weirs; Spurs = impermeable spurs; R Vanes = rock vanes; Soft $=$ toe rock, bank shaping, bankfull bench, and vegetation/bioengineering; Hard = hardened bank; Wood = woody revetments; $S$ Vanes $=$ submerged vanes; and Perm Spurs $=$ permeable spurs.

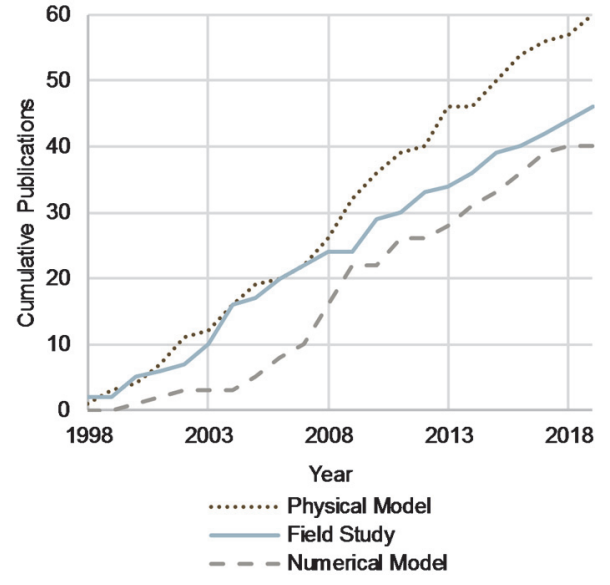

Figure 3. Cumulative publications by study type since 1998 .

Four primary study objectives were identified across the collection of studies reviewed: effects on bank erosion, hydraulics, sediment transport, and habitat (fig. 5). While many studies evaluated more than one effect, the most common study objective was the effect on sediment transport $(90 \%$ of the 146 studies), followed by the effect on bank erosion
(68\%), hydraulics (63\%), and habitat (34\%). Interestingly, the effect on bank erosion of streambank stabilization techniques was not the most commonly studied physical effect across all studies. However, the effect on bank erosion was the most common study objective for streambank management techniques, such as hard and soft engineering techniques and woody revetments. Scour induced by stabilization techniques can result in failure of any technique but is more prevalent with instream structures. Therefore, it is not surprising that the effect on sediment transport was the most commonly studied objective with instream structures. Furthermore, in addition to bank erosion mitigation, several instream structures have also been applied for maintaining navigation channels and improving pool habitat. The following sections provide a more in-depth review of each streambank stabilization technique, including definitions of structures, how each technique works, and the research and/or monitoring that has been conducted over the last 20 years.

\section{INSTREAM STRUCTURES}

The primary purpose of all instream structures, as shown in table 1, is to reduce applied shear stress, or the hydraulic force acting on a streambank. Impermeable flow deflectors,

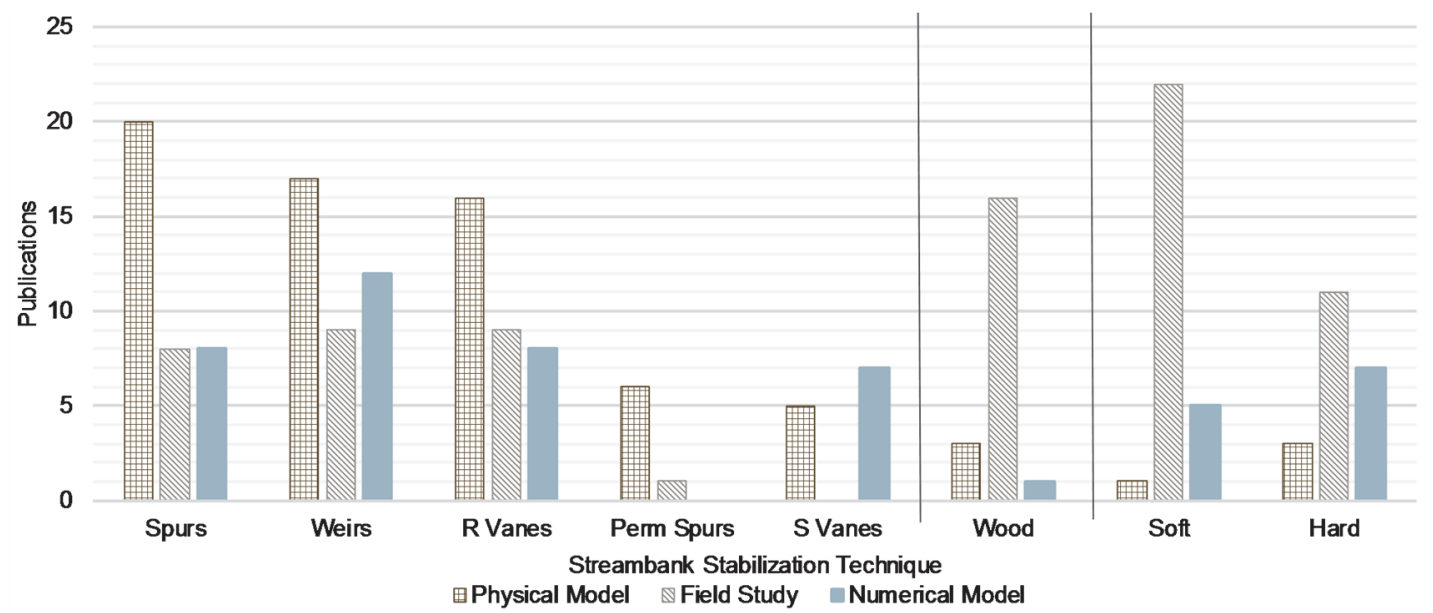

Figure 4. Primary study type by streambank stabilization technique: Spurs = impermeable spurs; Weirs = bendway weirs; $R$ Vanes = rock vanes; Perm Spurs = permeable spurs; S Vanes $=$ submerged vanes; Wood $=$ woody revetments; Soft $=$ toe rock, bank shaping, bankfull bench, and vegetation/bioengineering; and Hard $=$ hardened bank. 


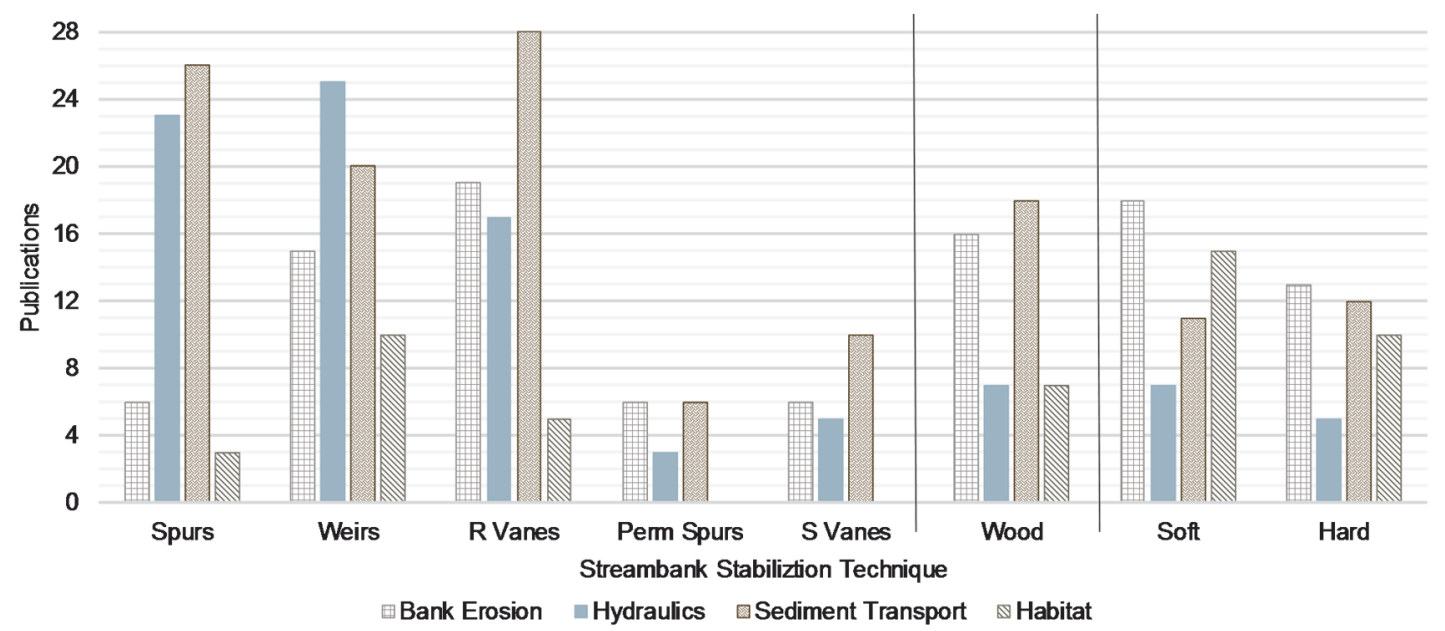

Figure 5. Study objective by streambank stabilization technique: Spurs = impermeable spurs; Weirs = bendway weirs; $R$ Vanes = rock vanes; Perm Spurs = permeable spurs; $\mathrm{S}$ Vanes = submerged vanes; Wood = woody revetments; Soft = toe rock, bank shaping, bankfull bench, and vegetation/bioengineering; and Hard = hardened bank.

often composed of rock, are likely the most common instream structure. Typically placed as a series of structures, impermeable flow deflectors are commonly used to redirect the thalweg away from the streambank toe by disrupting the natural, but erosive, helical flow pattern of meander bends (Abad et al., 2008; Jia et al., 2005, 2009). This helical flow pattern, or secondary current, is generated by the cross-section's velocity gradient and the centrifugal forces present through a meander bend. Another benefit of rock instream structures is that they can increase the spatial heterogeneity of aquatic habitat through the creation of scour holes and backwater areas (Shields et al., 1998a). In some cases, instream structures are placed on both sides of the stream, often referred to as double-wing deflectors, either to enhance navigation channels (Engelhardt et al., 2004, Sukhodolov et al., 2004; Schwartz and Kozerski, 2003; Ten Brinke et al., 2004) or pool habitat (Biron et al., 2004; Pretty et al., 2003; Thompson, 2002), in addition to providing streambank protection. Examples of these structures include impermeable spurs, bendway weirs, rock vanes, j-hook vanes, and stream barbs. The remaining instream structures, including permeable spurs, submerged vanes, and woody revetments, allow flow through and around them, dissipating flow energy and promoting deposition in the near-bank region. Woody revetments, both flow deflectors and toe wood, are included in this section.

The following sections provides a summary of the research and monitoring conducted from 1998 to 2019 on six types of instream structures. Some studies may appear in multiple instream structure summaries because (1) the researchers assessed multiple types of structures and/or (2) the researchers did not provide enough information about the instream structure to confidently place it in a particular category.

\section{Impermeable Spurs}

Impermeable spurs (fig. 1a) are tall structures built to the bankfull elevation or higher that force most flows around them, redirecting the current away from the streambank (Lagasse et al., 2009). These structures are often placed perpendicular to flow. Other names for these structures include jetties, spur dikes (or dykes), and groins (or groynes). Impermeable spurs are the oldest form of instream structures and have been documented in Europe as early as the 16th century (Sukhodolov et al., 2002; Uijttewaal, 2005). Although these structures have been used to stabilize streambanks in recent years, historically they were installed primarily to improve navigation by maintaining channel depth (Duan et al., 2009; Engelhardt et al., 2004; Ettema and Muste, 2004; McCoy et al., 2008; Uijttewaal, 2005; Sukhodolov et al., 2004; Teraguchi et al., 2011; Zhang et al., 2012).

The installation of impermeable spurs induces three-dimensional (3D) flow turbulence off the spur tip that is often described as a horseshoe, necklace, whirlpool, or tornadolike vortex (Duan, 2009; Koken, 2011; Koken and Constantinescu, 2008a, 2008b; Kothyari and Ranga Raju, 2001; McCoy et al., 2008; Zhang et al., 2009). These vortices cause scour at the spur (Koken and Constantinescu, 2008b) and have been found to be largely affected by spur dimensions, spacing, and flow conditions (Fazli et al., 2008; Koken and Gogus, 2015; Uijttewaal, 2005). In addition, impermeable spurs create a recirculation zone just downstream of the structure that has been found to induce deposition near the toe of the streambank (Koken and Constantinescu, 2008b; Sukhodolov et al., 2002; Uijttewaal et al., 2001). This recirculation zone has also been described as a wake vortex (Zhang et al., 2009) or gyre (Sukhodolov et al., 2002).

Since 1998, 36 studies on impermeable spurs have been published and are summarized in tables A1 through A3 in the Appendix. The majority of these were site-scale studies (92\%), conducted by engineers (88\%) in Asia (58\%), with physical modeling studies $(56 \%)$ being the most popular approach (fig. 6). Of both the physical and numerical models completed since 1998, the majority evaluated a single spur in a straight channel with a fixed bank and a low width-to-depth ratio. Numerical models $(22 \%)$ and field studies $(22 \%)$ have also been conducted, as shown in figure 6 . Of the eight numerical modeling studies, the majority used 3D modeling approaches. The effect on sediment transport was the most common research objective for impermeable spurs $(73 \%)$, while the effect on habitat was the least common (8\%; fig. 5). 


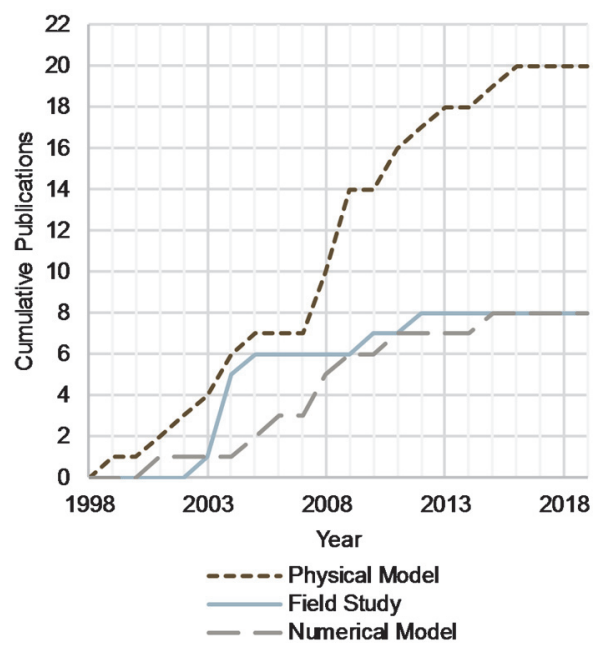

Figure 6. Temporal distribution of impermeable spur studies.

Most of the impermeable spurs evaluated in research were placed to extend from the streambed to the top of the streambank at an angle of $90^{\circ}$ from the tangent of the bank line, with the exception of a few studies (e.g., Acharya and Gautam, 2012; Koken, 2011; Scurlock et al., 2015; Teraguchi et al., 2011; Wu et al., 2005). Impermeable spur lengths and spacing varied, with lengths ranging from $1 \%$ to $58 \%$ of the channel width and spacing ranging from 0.01 to 4 times the length of the impermeable spur.

While some studies evaluated how spurs reduced velocities and induced deposition in the near-bank region (Acharya and Gautam, 2012; Burele et al., 2012; Teraguchi et al., 2011; Zhang and Nakagawa, 2009), Radspinner et al. (2010) and $\mathrm{Wu}$ et al. (2005) were the only studies to note the effectiveness of impermeable spurs in reducing bank erosion rates. Wu et al. (2005) found that the addition of spurs along a concave, eroding bank effectively reduced channel migration and that implementation of enough stabilization measures could shift a stream of interest from a braided channel form to a confined and meandering form. Similarly, based on a survey of stream restoration designers, Radspinner et al. (2010) found that instream structures, such as impermeable spurs, seemed to succeed in mitigating bank erosion on channels with high width-to-depth ratios and when multiple structures were installed.

Alternatively, most studies focused on the hydraulic and sediment transport effects of impermeable spurs. Duan (2009) and Duan et al. (2009) estimated that shear stress off the tip of impermeable spurs increased by as much as three to eight times the average, resulting in scour. Scour is a key design consideration with impermeable spurs, as excessive scour can result in structure failure (Zhang et al., 2012). Researchers noted that scour dimensions and/or applied shear stress increased (1) with increasing length (Fazli et al., 2008; Koken and Gogus, 2015; Nasrollahi et al. 2008), turbulence (Duan et al., 2009; Koken and Constantinescu, 2008a), Froude number (Fazli et al., 2008; Pandey et al., 2016), and sediment uniformity (Zhang et al., 2012) and (2) at locations downstream of a meander apex (Fazli et al., 2008). Further, Koken (2011) found that $90^{\circ}$ spurs, or spurs placed perpendicular to flow, resulted in the greatest bed shear stress, in contrast to $60^{\circ}$ (pointed upstream) and $120^{\circ}$ (downstream) spurs. Alternatively, Deghani et al. (2013) and Ghodsian and Vagheffi (2009) studied the bed scouring effect of adding a wing to the spur tip (creating an L-shaped or T-shaped spur). While investigating T-shaped spurs, Ghodsian and Vagheffi (2009) found similar results as regular spurs, with scour increasing with increasing length and Froude number, but they also noted that scour was greatest on the upstream side of the spur. For L-shaped spurs, Deghani et al. (2013) observed less scour in the vicinity of adjusted spurs in comparison to regular impermeable spurs. Furthermore, the researchers found that angling the wing of the spur upstream resulted in even less scour (Deghani et al., 2013).

Using results from physical and numerical models, researchers have developed scour prediction equations based on spur dimensions (Fazli et al., 2008; Nasrollahi et al., 2008; Pandey et al., 2016), side slopes (Rahman and Haque, 2004; Rahman and Muramoto, 1999), location (Fazli et al., 2008), and flow conditions (Fazli et al., 2008; Nasrollahi et al., 2008; Pandey et al., 2016). Kothyari and Ranga Raju (2001) noted that impermeable spurs function similarly to bridge abutments, and they successfully employed abutment and pier scour prediction equations to predict scour depth for spurs. Alternatively, Scurlock et al. (2015) developed equations to predict the hydraulic effects induced by rock flow deflectors based on structure dimensions. As noted by Rahman and Muramoto (1999) and Scurlock et al. (2015), these prediction methods should be used with caution, as they are limited to systems that have channel, sediment, and/or design parameters similar to the parameters for which the prediction method was developed.

The depositional zone in the wake region of a spur has also been evaluated. Sukhodolov et al. (2002) studied velocity patterns for a range of spur lengths and spacings and found that the greatest deposition occurred in the center of a gyre, where the average velocity is lowest. The researchers also developed a simplified depositional pattern classification system of the plan view distribution of deposited sediment. Their classification system consists of seven classes, from weak deposition to uniform and complete deposition between spurs (Sukhodolov et al., 2002). On the Rhine River in the Netherlands, Ten Brinke et al. (2004) found that erosion of depositional features between spurs was caused primarily by navigation and that deposition occurred after a five-year return interval or greater flood event.

Effects on water quality parameters, such as suspended sediment and contaminants, were also of interest. Duan and Nanda (2006) were able to effectively model changes in suspended sediment in a zone of multiple spurs using a twodimensional (2D) numerical model. The researchers showed that suspended sediment concentrations increased near the spur tip following construction. Further, Sukhodolov et al. (2004) found that suspended sediment concentrations decreased from the tip of the spur to the bank and that velocities within the spur field increased and then decreased from the channel bottom to the free surface. This decrease was caused by the turbulent nature of the free surface, which was attributed to waves from either wind or navigation. Similarly, Uijttewaal et al. (2001) showed that exchange of dissolved matter was greatest at the spur-river interface, mainly due to 
the 2D nature of the wake vortices. Schwartz and Kozerski (2003) were concerned with the mobility of fine-grained sediment deposits during turbulent events, as contaminants are often attached to these sediment particles, and recommended removing these fine-grained deposits to prevent ecosystem degradation. Finally, McCoy et al. (2008) used their 3D model to better understand contaminant transport between the spur field and the channel.

Engelhardt et al. (2004) was the only research team that studied the direct effect that spurs have on biotic processes by observing how various spur configurations affected phytoplankton residence times. Similar to Sukhodolov et al. (2002), the field study by Engelhardt et al. (2004) showed that water residence times and phytoplankton growth rates increased with increasing spur spacing and decreasing discharge. Giri et al. (2003) conducted the only reach-scale study and observed a change in the velocity distribution along the downstream, untreated meander bend following installation of spurs upstream.

A few research groups recognized the importance of developing laboratory and numerical models to assist with design. Ettema and Muste (2004) found that flow characteristic distortions increased with decreasing physical model size. In addition, Giri et al. (2004) and Nagata et al. (2005) reported that a $2 \mathrm{D}$ or 3D model can effectively simulate the hydraulic effects of spurs, but only a 3D numerical model can reliably simulate the effects on sediment transport (Nagata et al., 2005).

Finally, several studies compared impermeable spurs to other types of instream structures. Teraguchi et al. (2011), Uijttewaal (2005), and Zhang and Nakagawa (2009) compared impermeable spurs to permeable spurs. Uijttewaal (2005) showed that impermeable spurs with a flat-sloped tip were most effective at weakening the horizontal velocity gradient between the spur field and the main channel and thus reducing scour, as compared to steep-sloped tips and permeable spurs. Zhang and Nakagawa (2009) evaluated impermeable spurs with a vertical tip and found that impermeable spurs had the greatest effect on channel flow structure. Teraguchi et al. (2011) obtained similar results and noted that impermeable spurs were not as effective as permeable spurs at reducing scour and inducing deposition. Finally, Acharya and Gautam (2012) conducted a field study on impermeable spurs, bendway weirs, and toe rock, noting that impermeable spurs were the least effective in reducing nearbank velocities. These studies and their comparison structures are discussed again in the following sections.

\section{Bendway Weirs}

Thomas Pokrefke of the U.S. Army Corps of Engineers (USACE) first introduced bendway weirs in the late 1980s as a means to improve navigation along meander bends of the Mississippi River while also protecting the outside bank from erosion (Dave Derrick, USACE, personal communication, 20 September 2019). Bendway weirs (fig. 1b) are lowlying, flat-crested, impermeable structures that are often pointed upstream. They are intended to force flow around and, at times, over them (Biron et al., 2004; Khosronejad et al., 2017). Because of their similarity to impermeable spurs, other names for bendway weirs include submerged spur dikes and submerged groins.

A bendway weir is similar to an impermeable spur in that it shifts the high flow velocity core to just off the tip of the weir (Abt et al., 2016; Jia et al., 2005; McCoy et al., 2007). The key difference is that a weir is also designed to be submerged during certain flow events. This submergence results in an even more complex 3D flow regime around and over the structure (Kuhnle and Alonso, 2013; McCoy et al., 2007; Uijttewaal, 2005), affecting both scour near the structure and deposition in the wake region (Yossef and deVriend, 2010). Although similar vortices along the cross-section and vertical plane of a channel, as observed with an impermeable spur, also occur with a bendway weir at low flow, flows that overtop the weir result in additional turbulence of the longitudinal plane of the channel that dominate scour depth patterns around the bendway weir (Kuhnle and Alonso, 2013; Kuhnle et al., 2008). In other words, as flow travels over the top of a weir, a 3D circulation cell forms on the downstream face of the weir, resulting in scour (Kuhnle et al., 1999, 2008). Additionally, submerged bendway weirs dampen and/or reverse the natural helical flow pattern inherent to meander bends (Jia et al., 2009). Bendway weirs also influence the water surface by creating a backwater effect on the upstream side of the structure (Azinfar and Kells, 2007; Elawady et al., 2000; Tritthart et al., 2009). Level of submergence, influenced by weir height and flow depth, as well as the length of the weir, greatly affect backwater conditions and, as a result, flow behavior and turbulence near a bendway weir.

A total of 38 bendway weir publications were identified and are summarized in tables A4 through A6 in the Appendix. Since 1998, site-scale studies $(89 \%)$ with varying flows $(66 \%)$, conducted by engineers $(82 \%)$ in North America (71\%), were the most common type of bendway weir study. As shown in figure 7, physical modeling studies were the most common assessment technique (45\%), followed by numerical studies (32\%) and field studies (24\%). Furthermore, researchers were more interested in the effects of bendway weirs on hydraulics (66\%) and sediment transport $(53 \%)$ than the effects on bank erosion (39\%) and habitat (26\%) (fig. 5).

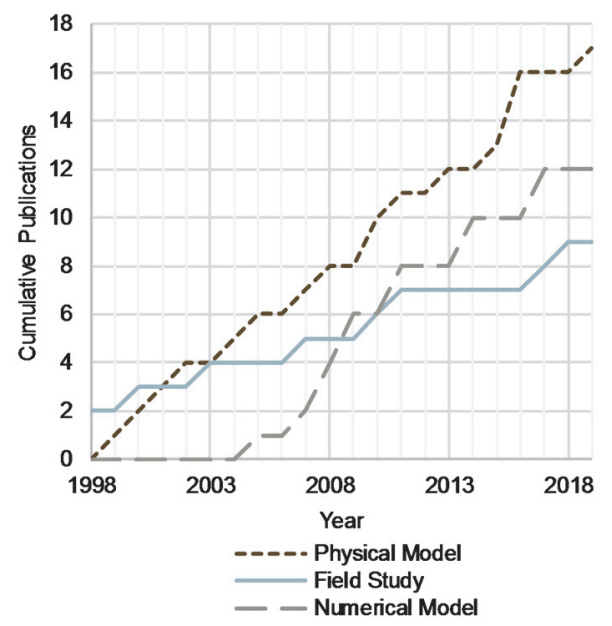

Figure 7. Temporal distribution of bendway weir studies. 
Until recently, many of the physical modeling studies have evaluated a single bendway weir in a straight flume with a fixed bank. Since 2010, more physical models have been developed that assess how multiple weirs affect the helical secondary current induced by a meandering planform (e.g., Abt et al., 2016; Cunningham and Lyn, 2016; Hemmati and Daraby, 2019; Kinzli and Thornton, 2010; Scurlock et al., 2015), and one study even incorporated an erodible bank (Cunningham and Lyn, 2016). Most of the physical modeling studies were conducted in flumes with a low width-todepth ratio and slope. In numerical modeling studies, 3D models have been applied the most since 1998. Further, the majority of research groups that employed numerical models to simulate multiple bendway weirs in meandering channels used models that are publicly or commercially available, as opposed to models that were custom-built by the research group.

When evaluating the spatial characteristics of bendway weir studies, only $16 \%$ of the studies investigated effects at reach scale, and none were completed at river scale. Angles of bendway weirs, pointed upstream from the tangent of the bank line, ranged from $20^{\circ}$ to $135^{\circ}$, meaning that some researchers evaluated the performance of structures pointed downstream. The height and length of bendway weirs also varied, with height never exceeding the bankfull elevation and length ranging from $4 \%$ to $58 \%$ of the channel width. Biron et al. (2004) and Pretty et al. (2003) were the only studies that evaluated double-wing bendway weirs, a common technique used to also improve fish habitat by creating scour pools.

The effectiveness of bendway weirs in reducing bank erosion was assessed in 15 studies. Most research groups measured hydraulic and sediment transport characteristics to infer structure effectiveness in reducing bank erosion. Experiments showed that the thalweg was effectively moved to the tip of the weir, decreasing velocity near the bank and, in some cases, inducing deposition (Acharya and Gautam, 2012; Cunningham and Lyn, 2016; Elawady et al., 2001; Kuhnle et al., 1999, 2002). However, bank erosion may still occur due to variation in structure dimensions (Biron et al., 2004; Cunningham and Lyn, 2016; Kuhnle et al., 2002), structure angle (Khosronejad et al., 2017), level of submergence (Abad et al., 2008; Biron et al., 2004), and location along a meander bend (Cunningham and Lyn, 2016; Hemmati and Daraby, 2019; Khosronejad et al., 2017). Cunningham and Lyn (2016) and Kuhnle et al. (1999) agreed that taller weirs provide the greatest bank protection, but may result in more scour on the downstream side of the weir near the streambank toe, likely due to induced wake vortices. This finding is contrary to the results reported by Biron et al. (2004) and Elawady et al. (2001), who found that low weirs provided the greatest bank protection by minimizing scour. These differences are likely attributable to variable study design parameters, such as type of flows tested, planform, bank composition, and weir design characteristics (see table A4 in the Appendix for more information).

Only a few research groups attempted to quantify bank erosion rates following installation of bendway weirs. In the physical modeling study that used an erodible bank, Cunningham and Lyn (2016) noted that bank erosion might still occur downstream of the apex of a meander bend, likely due to cross-channel flow that occurs during high flow events (Jia et al., 2009). Furthermore, Cunningham and Lyn (2016) observed erosion along the streambank following weir submergence due to an increase in localized shear stresses. A similar observation was made by Abad et al. (2008) when comparing their numerical modeling simulation to field conditions. Increased erosion during submergence is contrary to the results of Biron et al. (2004), who concluded that bank erosion rates would increase when weirs were unsubmerged due to an observed increase in bed scour near the structure. Finally, as mentioned previously, Radspinner et al. (2010) reported improved bank erosion protection when multiple structures were placed on streams with high width-to-depth ratios.

When comparing other stabilization techniques to bendway weirs, Hemmati et al. (2016) pointed out that bendway weirs were more effective than rock vanes in redirecting flow away from a streambank, but as a result, scour near the tips of the weirs also increased (Hemmati and Daraby, 2019). Elhakeem et al. (2017), Bressen et al. (2014), and Papanicolaou et al. (2011a) applied the 2D hydrodynamic model FESWMS to show that using a combination of weirs and rock vanes provided an optimal shift in flow characteristics that can reduce bank erosion in streams in Iowa. As mentioned in the previous section, Acharya and Gautam (2012) conducted a field study on impermeable spurs, bendway weirs, and toe rock and found that bendway weirs, in combination with toe rock, were the most effective approach for controlling flow velocities in the near-bank region. Finally, Dave and Mittlestet (2017) monitored and estimated the installation costs of several stabilization techniques and found that, while some treatment approach was better than none, rock flow deflectors were the least cost-effective approach for reducing bank erosion.

Hydraulic effects of bendway weirs have been studied extensively. Hydraulic conditions are influenced by weir dimensions (Elawady et al., 2000; Kuhnle et al., 2008), angle (Elawady et al., 2000), and shape (Kuhnle et al., 2008). Kuhnle and Alonso (2013), Kuhnle et al. (2008), and Uijttewaal (2005) focused their efforts on understanding the 3D hydraulic effects at and around $90^{\circ}$ bendway weirs of varying dimensions. Azinfar and Kells (2007) and Elawady et al. (2000) investigated the backwater effect created by submerged weirs, and both studies agreed that just-submerged weirs had the greatest effect on backwater conditions. Additionally, Azinfar and Kells (2007) developed a model to estimate backwater effects that depends on weir height, channel constriction (influenced by structure length and angle), flow depth, and Froude number. Finally, Kinzli and Thornton (2010) and Scurlock et al. (2015) developed prediction equations for the hydraulic effects induced by bendway weirs to assist with design, while Abt et al. (2016) developed rock sizing criteria based on the estimated maximum velocity at the tip of a weir.

Similar to impermeable spur research, scour prediction is a key component in design, not only for stability of the structure and streambank but also for habitat improvement through the creation of pools. Research showed that scour depth off the tip of a weir increased with increasing structure 
height (Biron et al., 2004; Cunningham and Lyn, 2016; Elawady et al., 2001) and below the apex of a meander bend (Cunningham and Lyn, 2016; Hemmati and Daraby, 2019; Jia et al., 2009; Khosronejad et al., 2017). Furthermore, scour volume near a bendway weir increased with decreasing crest slope (Hemmati and Daraby, 2019) and with increasing length (Elawady et al., 2001), weir submergence (Elawady et al., 2001; Kuhnle et al., 1999), and angle (Kuhnle et al., 2002). Kuhnle et al. (1999) developed an equation to predict the scour volume for weirs placed perpendicular to flow. Additionally, based on results from a physical model, Elawady et al. (2001) reported that scour was greatest on the upstream side of a bendway weir. In terms of effects on deposition, Yossef and deVriend (2010) observed net deposition within the weir field under both submerged and unsubmerged flow conditions, while Khosronejad et al. (2014a) observed dune formation just downstream of bendway weirs and rock vanes in their 3D numerical model simulation.

Shields et al. (1998a, 1998b, 2000) provided the most case studies on the effects of bendway weirs on habitat. Their research on aggradational, warmwater streams in Mississippi found that bendway weirs created wide pools and increased shoreline, resulting in a shift of fish composition along the site from a run-dwelling assemblage of cyprinids to large, pool-dwelling centrarchids. Similarly, Shih et al. (2008) noted improvements to fish habitat for endemic species in Taiwan if the number and spacing of the structures and the Froude number were considered in the design. In contrast, Pretty et al. (2003) found that rock flow deflectors that induced physical changes to streams had minimal positive effects on fish habitat. They noted that this could have been due to the poor water quality of the streams surveyed in their study. Finally, Papanicolaou et al. (2011b) showed that notching submerged weirs that were already installed on the Missouri River in the U.S. did not increase shallow water habitat.

In terms of benthic macroinvertebrate habitat, $\mathrm{Li}$ et al. (2018) observed improved habitat quality at weir sites. Alternatively, Cooperman et al. (2007) were unable to decipher benthic habitat changes due to the lack of pre-construction data, but they noted increases in vegetation and decreases in channel width at stabilized sites. Tritthart et al. (2009) evaluated the effects that weirs have on flow field water residence times, and thus phytoplankton growth and nutrient dynamics, noting that just-overtopped weirs provided the longest residence times and the greatest benefits for phytoplankton growth. Finally, McCoy et al. (2007) studied contaminant exchange between the weir field and main channel, finding that contaminant transport increased during times of weir submergence.

\section{Rock Vanes}

Rock vanes, or stream barbs (fig. 1c), are partially submerged flow deflectors first described in the 1990s (Johnson et al., 2001; Rosgen, 1996). They are similar to bendway weirs except that the crests of these structures slope from as high as the bankfull elevation to the streambed. Rock vanes can have either a triangular or a trapezoidal cross-sectional shape, depending on the crest width. J-hook vanes are identical to rock vanes but also incorporate a hooked-shaped rock sill at the tip of the structure (Khosronejad et al., 2013, 2014a; Pagliara et al., 2013; Pagliara and Kurdistani, 2015; Zhou and Endreny, 2012). Because the tips of rock vanes are always submerged, complex 3D flow occurs in and around these structures (Uijttewaal, 2005). When placed in a series along the outside of a meander bend, a secondary flow cell is created that opposes the flow created by the bend itself (Bhuiyan et al., 2010; Johnson et al., 2001) and shifts the flow from the bank to the center of the channel (Matsuura and Townsend, 2004; Zhou and Endreny, 2012). Due to the angled crest of the structure and its continuous submergence, scour hole depths near the tip of the structure tend to be shallower in comparison to those created by bendway weirs and impermeable spurs (Bhuyian et al., 2009, 2010; Hemmati et al., 2016; Hemmati and Daraby, 2019). Unlike impermeable spurs and bendway weirs, wake vortices are generally not formed (Bhuyian et al., 2010) but depend mainly on vane dimensions and/or flow depth (Fox et al., 2005; Jamieson et al., 2013a, 2013b; Zhou and Endreny, 2012).

Since 1998, 33 rock vane studies have been published and are summarized in tables A7 through A9 in the Appendix. The majority of these have been site-scale studies $(85 \%)$ on a meandering stream (79\%) with varying flow conditions $(73 \%)$. Furthermore, engineers $(82 \%)$ in North America (73\%) have conducted most of these studies. Almost half of the studies have been conducted in laboratory flumes ( $48 \%)$, followed by field studies (27\%) and numerical modeling studies (24\%), as shown in figure 8 . The effect of rock vanes on bedload transport was the leading study objective (85\%), followed by bank erosion (58\%), hydraulics (52\%), and habitat (15\%, fig. 5).

Modeled structure and stream characteristics were much more variable, as compared to studies of impermeable spurs and bendway weirs. While fixed bank conditions and low width-to-depth channels were still commonly used in rock vane physical models, more recent models have incorporated varying site characteristics, such as Hemmati et al. (2016), Jamieson et al. (2013a, 2013b), and Karki et al. (2018). When reviewing the numerical modeling studies, 2D and 3D models have been equally employed. Similar to the bendway

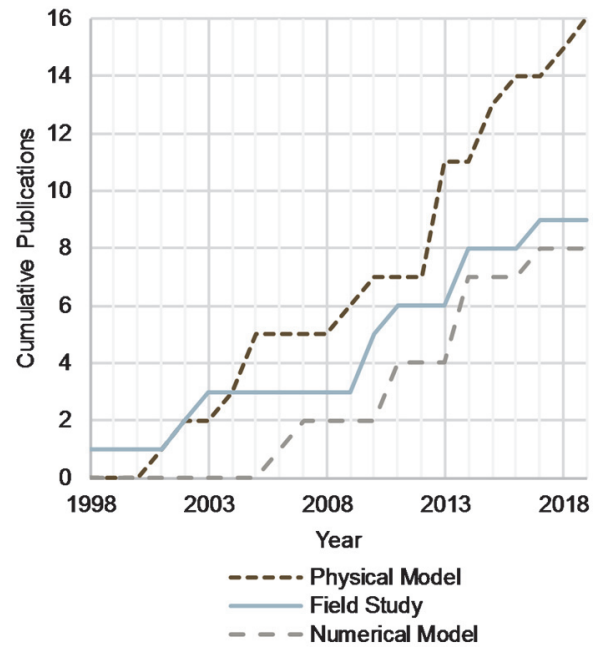

Figure 8. Temporal distribution of rock vane studies. 
weir numerical models, most numerical modeling studies of rock vanes used codes that are publicly or commercially available.

Although some research groups, especially those conducting field studies, did not report structure design properties, the reported angles ranged from $20^{\circ}$ to $120^{\circ}$ upstream from the bank tangent line (i.e., both upstream and downstream pointed vanes have been evaluated). Lengths ranged from $20 \%$ to $75 \%$ of the channel width, while maximum height was at bankfull stage. Thompson (2002) and Pretty et al. (2003) were the only rock vane studies that also evaluated double-wing flow deflectors. Unlike the studies of impermeable spurs and bendway weirs, several research groups investigated the effects of rock vanes at reach scale, although not at river scale.

Similar to other rock flow deflector studies, understanding and quantifying bank erosion reduction after implementation of rock vanes was not a top research objective. In the studies that investigated bank erosion, the conclusions on bank erosion reduction were often based on the structure's ability to shift the flow and scour away from an eroding bank and potentially induce deposition in the near-bank region. Based on these kinds of studies, researchers noted that bank erosion can be reduced by the implementation of rock vanes if the structure size (Bhuyian et al., 2010; Jamieson et al., 2013a, 2013b; Matsuura and Townsend, 2004), angle (Bhuyian et al., 2010; Matsuura and Townsend, 2004), number (Bhuyian et al., 2010; Elhakeem et al., 2017; Jamieson et al., 2013a, 2013b; Radspinner et al., 2010), and spacing (Elhakeem et al., 2017; Fox et al., 2005; Jamieson et al., 2013a, 2013b) are properly considered in the design. Furthermore, Hemmati et al. (2016) and Hemmati and Daraby (2019) noted that rock vanes were more effective than bendway weirs in reducing scour and maximizing deposition in the near-bank region.

Several case studies directly evaluated the effectiveness of rock vanes in reducing bank erosion. As mentioned in the previous section, the monitoring studies conducted by Bressan et al. (2014), Dave and Mittlestet (2017), and Elhakeem et al. (2017) showed that rock flow deflectors decreased erosion rates on streams in the Midwestern U.S. Additionally, using 2D numerical models, researchers showed that rock vanes, in combination with other stabilization techniques, were effective in reducing near-bank velocities (Papanicolaou et al., 2011a) and lateral retreat rates (Niezgoda and Johnson, 2006). Furthermore, Karki et al. (2018) showed that vane installation reduced erosion rates in meandering channels with varying sinuosity. Alternatively, Buchanan et al. (2014) found that stream restoration projects using rock vanes and other stabilization techniques might have a "break-in" period, meaning that a few years may be required for the restoration project to settle, adjust, and stabilize before the project objectives are met. Elhakeem et al. (2017) also observed this break-in period for a stabilization project in Iowa. In response to this observation, Buchanan et al. (2014) emphasized the importance of understanding sediment yields, designing resilient and conservative structures, establishing vegetation, preparing for maintenance activities, and conducting long-term monitoring.
Miller and Kochel (2010, 2013) obtained different streambank erosion monitoring results. Their research found that channel realignment and the incorporation of rock vanes, $\mathrm{j}$-hook vanes, and root wads were prone to failure in less than ten years, especially after flood events. However, Miller and Kochel $(2010,2013)$ also observed that rock vanes and $\mathrm{j}$-hook vanes were less susceptible to failure than rood wads in North Carolina streams. Additionally, Radspinner et al. (2010) showed that design and site features, such as the number of rock vanes installed and the channel's width-to-depth ratio, might affect long-term project success. When assessing reach-scale effects, Thompson (2002) noted that failing structures that are not maintained may make it difficult for the stream to self-adjust and regain stability over the long run. In addition, several researchers noted that failure to incorporate an understanding of sediment transport in the design of instream structures may result in increased bank erosion rates downstream (Bhuiyan et al., 2009; Buchanan et al., 2014; Khosronejad et al., 2013). However, Bhuiyan et al. (2009) noted that properly designed rock vanes have the smallest impact on localized scour and deposition, when compared to impermeable spurs and bendway weirs, as they generally do not create a recirculation zone in the near-bank region (Bhuiyan et al., 2010).

The hydraulic effects of rock vanes and their impact on sediment transport have also been studied extensively. Fox et al. (2005) observed that rock vanes have three distinct flow regions: the main core, shear layer, and stagnant wake. The main core region contains the fastest flow and highest shear stress and occurs just off the tip of the structure, following the downstream direction of flow. The stagnant wake region, located just downstream of the structure near the streambank, occurs when vanes are not fully submerged. Finally, the shear layer is located between these two regions and is the area that is most affected by overtopping of the structure. The shear layer only occurs when structure angles are greater than $50^{\circ}$, as smaller angles do not create this excessive energy dissipation. These flow regions have been applied to other rock flow deflectors, and Abad et al. (2008) confirmed these regions when measuring flow characteristics around bendway weirs.

Rock vane dimensions and angle, as well as overall site conditions, can have a large effect on scour. Researchers noted that scour depth increased with increasing rock vane height, width, and length (Jamieson et al., 2013a, 2013b; Pagliara et al., 2013; Pagliara and Kurdistani, 2015) and decreasing crest slope (Hemmati et al., 2016, 2019). Bhuyian et al. (2010) and Johnson et al. $(2001,2002)$ found that a maximum vane height at bankfull was most effective at minimizing scour, as compared to Matsuura and Townsend (2004), who found that vane heights between $33 \%$ and $50 \%$ of bankfull height were best. Key differences among these four studies include varying flow conditions, planform, bed sediment, length, and spacing, as summarized in table A7 in the Appendix. In terms of rock vane angle, Bhuyian et al. (2010), Johnson et al. (2001, 2002), and Matsuura and Townsend (2004) agreed that multiple vanes angled at $30^{\circ}$ minimized scour near the structure. Alternatively, in terms of site conditions, an increase in scour depth was observed 
with increasing meander bend radius (Pagliara and Kurdistani, 2015) and at the upstream and downstream ends of a meander (Hemmati and Daraby, 2019). Furthermore, Pagliara et al. (2013) observed that the scour hole moved toward the structure when the Froude number decreased.

Numerical simulations were performed to optimize the design and observe the sediment transport effects of vanes. Minor et al. (2007) and Khosronejad et al. (2014b) successfully employed 3D numerical models to assess sediment transport processes around vanes with varying arrangements. Effects on both scour and deposition were evaluated by Khosronejad et al. $(2013,2014 a)$ using a calibrated 3D numerical model. Both studies reported that the sediment scoured by rock vanes moved slowly downstream in the form of dunes.

Finally, four studies evaluated the effects of rock vanes on aquatic habitat. Thompson (2002) and Pretty et al. (2003) agreed that rock and wood deflectors generally do not meet pool depth expectations and/or enhance fish habitat. In contrast, Shields et al. (1998a) found that vane installation could improve pool availability for some warmwater fishes, especially in aggradational zones of unstable streams. Additionally, Schiff et al. (2011) found localized improvements in macroinvertebrate habitat along stabilized sites that used rock flow deflectors, woody revetments, and/or bioengineering approaches but observed no improvement in macroinvertebrate habitat at reach scale, suggesting a larger watershedscale problem.

\section{Permeable Spurs}

The purpose of permeable spurs is to slow stream velocities and induce deposition in the vicinity of the protected streambank by allowing flow through the structure (Gu et al., 2011; Lagasse et al., 2009; Zhang and Nakagawa, 2009). Permeable spurs can be made with a variety of materials; figure $1 \mathrm{~d}$ shows an example of a fence-type spur. Other names for these structures include permeable spur dikes, retardance spurs, retarders, bandal-type structures, and jetties.

Seven studies were identified that investigated the physical effects of permeable spurs. These studies are summarized in table A10 in the Appendix. Most studies were conducted by engineers (100\%) in Asia (71\%). Research groups mainly evaluated site-scale $(100 \%)$ bedload effects $(86 \%)$ of permeable spurs during a single flow event $(71 \%)$ in a laboratory setting $(86 \%)$, as shown in figure 9 . All physical modeling studies were conducted in straight flumes with a fixed bank. Porosity, or the ratio of the void area to the total area, of the evaluated spurs varied between 0.2 and 0.9 , while the length of the spurs was not greater than $40 \%$ of the channel width.

The effects of permeable spurs on bank erosion was an objective of three of the seven studies. As previously discussed, research groups showed that permeable spurs were more effective than impermeable spurs at reducing velocities (Uijttewaal, 2005; Zhang and Nakagawa, 2009) and scour depths (Nasrollahi et al., 2008; Teraguchi et al., 2011), while inducing deposition in the near-bank region (Teraguchi et al., 2011). However, Teraguchi et al. (2011) found that using a hybrid structure, called a bandal-like structure, resulted in optimal scour at the tip of the structure and deposition in the

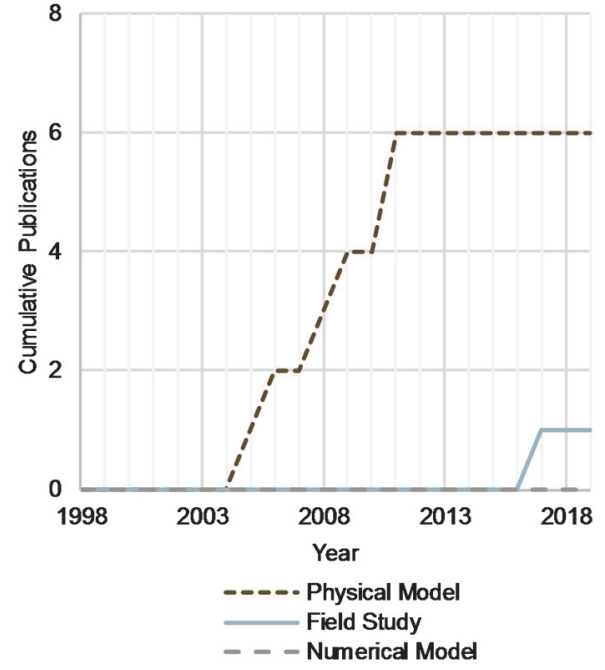

Figure 9. Temporal distribution of permeable spur studies.

near-bank region, while Zhang and Nakagawa (2009) recommended using a combination of permeable and impermeable spurs to achieve an optimal channel morphology. Additionally, Dave and Mittlestet (2017) showed that permeable spurs were more cost-effective than rock vanes, hardened streambanks, woody revetments, toe rock, or bank shaping for reducing bank erosion on a stream in the Midwestern U.S. Their long-term monitoring study reported that permeable spurs reduced erosion rates by more than $70 \%$ following installation (Dave and Mittlestet, 2017).

Researchers also investigated effects on sediment transport (86\%) and hydraulics (43\%). Nasrollahi et al. (2008) and Rahman et al. (2006) developed equations to estimate variations in scour depth near permeable spurs. Gu et al. (2011) evaluated the effects of permeable spurs on suspended sediment, reporting that concentrations decreased gradually through a permeable spur field due to fine sediment deposition on the upstream end of the spur field. In terms of the hydraulic effects, physical models showed that the direction of flow changes very little within a permeable spur field (Gu et al., 2011; Zhang and Nakagawa, 2009).

Although no studies directly focused on assessing the physical effects of permeable spurs using a numerical model, Zhang and Nakagawa (2009) calibrated a 3D model for use in permeable spur design and monitoring based on results from a laboratory model. Finally, the effects that permeable spurs might have on habitat have not yet been assessed.

\section{Submerged Vanes}

Based on the aerodynamics of a wing, submerged vanes, also referred to as Iowa vanes (fig. 1e), were developed by Odgaard and Kennedy (1983) at the Iowa Institute of Hydraulic Research as an economical means to stabilize streambanks. Submerged vanes are angled arrays or rows of foils placed near the toe of an eroding meander bend that are designed to diminish secondary currents and thus reduce applied shear stress (Odgaard and Kennedy, 1983) and induce deposition (Ouyang et al., 2008; Ouyang, 2009; Ouyang and Lin, 2016; Ouyang and Lu, 2016). They are the only instream structure that does not attach to the streambank. When optimally placed along a bend, submerged vanes 
weaken the secondary current by generating two counter-rotating vortices and a horseshoe vortex for high-angled vanes $\left(>40^{\circ}\right)$ or a single vortex for low-angled vanes (Sinha and Marelius, 2000; Sharma et al., 2016; Voisin and Townsend, 2002). In addition to bank stabilization, these structures have been employed to control sediment deposition (Gupta et al., 2010) and improve navigation (Flokstra, 2006).

Since 1998, twelve studies have been published on submerged vanes and are summarized in tables A11 and A12 in the Appendix. Although this technique was first introduced in North America, research groups in Asia have conducted the majority of these studies (67\%). Furthermore, all of the studies found were conducted by engineers, reviewing only the site-scale effects induced by a single flow event. Most of the modeling studies used a low width-to-depth, meandering channel with a fixed bank and mobile bed. Unlike the previously mentioned instream structures, numerical models were the most popular approach (58\%), followed by physical models (42\%), as shown in figure 10 . Of the numerical models presented, a one-dimensional (1D) model developed by Ouyang (2009) was the most commonly used. Although some field studies have been conducted, none were found that have been peer-reviewed and therefore are not included in this summary.

The primary objective for $83 \%$ of the studies was to evaluate the effect on bedload transport. Only one study physically measured changes in bank erosion rates following installation of submerged vanes in a laboratory flume with an erodible bank (Dey et al., 2017), while five studies evaluated hydraulic and sediment transport effects that might influence bank erosion rates (Ouyang et al., 2008; Ouyang, 2009; Ouyang and Lin, 2016; Ouyang and Lu, 2016; Voisin and Townsend, 2002). The effects of submerged vanes on hydraulics were assessed in $42 \%$ of the studies. Finally, no studies were found that evaluated the effects that these structures might have on habitat (fig. 5).

Nine of the 12 studies on submerged vanes provided optimal design dimensions and spacing, largely based on the bedload transport effect of the structures and, in some cases, bank erosion reduction. Definitions of "optimal" varied across the studies. While most researchers wanted to

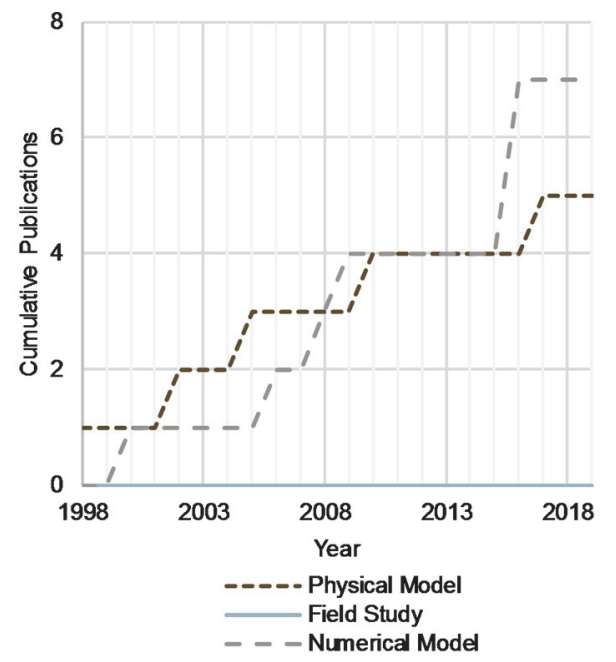

Figure 10. Temporal distribution of submerged vane studies.
(1) minimize scour while maximizing flow turbulence to induce deposition (Dey et al., 2017; Gupta et al., 2010; Ouyang et al., 2008; Ouyang, 2009; Ouyang and Lin, 2016; Ouyang and $\mathrm{Lu}, 2016$; Voisin and Townsend, 2002), others wanted to (2) maximize flow turbulence to induce deposition and improve the design of submerged vanes to withstand the scour that would occur (Marelius and Sinha, 1998; Sharma et al., 2016; Tan et al., 2005).

Voisin and Townsend (2002) pointed to vane height and angle as having the greatest effects on hydraulics and sediment transport in meandering streams with low width-todepth ratios. Alternatively, Ouyang et al. (2008) and Ouyang and $\mathrm{Lu}$ (2016) found that vane spacing had the greatest effect on hydraulics and sediment transport in meandering streams with varying width-to-depth ratios. In addition to differences in width-to-depth ratios, these contradictory results may also be due to varying vane design characteristics (see tables A11 and A12 in the Appendix for more information). Ouyang et al. (2008) and Ouyang and Lu (2016) also noted that increasing the spacing and number of submerged vanes resulted in more deposition. In terms of angle, results varied for designs with the same objective, with reported optimal angles ranging from $2^{\circ}$ to $40^{\circ}$ to meet objective 1 above and from $30^{\circ}$ to $40^{\circ}$ to meet objective 2 . Furthermore, only two of the studies provided an optimal height (Tan et al., 2005; Voisin and Townsend, 2002), with different results likely due to varying design objectives.

Alternatively, some researchers used modeling approaches to determine design features that most influenced the ability of vanes to achieve stated objectives. Ouyang (2009) and Ouyang and Lin (2016) tested various shapes to achieve objective 1 and found that trapezoidal submerged vanes were more effective than rectangular and parallelogram-shaped submerged vanes. Additionally, Gupta et al. (2010) provided a novel approach to improve a rectangular submerged vane design by incorporating a circular collar at the base of the vane to decrease scour and prevent dislodging. Finally, Flokstra (2006) observed differences in the flow characteristics described by submerged vane developers (Odgaard and others) and the results from their 2D model simulation, thus questioning the validity of the wing theory to describe flow patterns near submerged vanes.

\section{Woody Revetments}

Woody revetments (fig. 1f) are large, non-living woody debris structures that are anchored in the streambank, and at times in the streambed, to provide roughness and redirect flow from the toe of the streambank. Trees can be placed parallel with the flow along the toe, often referred to as toe wood, acting as both flow deflection and toe protection (e.g., Shields et al., 2006) or at an angle pointed in the upstream or downstream direction (e.g., Pagliara and Kurdistani, 2017; Pagliara et al., 2015a, 2015b) on one or both sides of a stream (e.g., Thompson, 2002). Woody revetments placed within the stream have also been called log deflectors (Pagliara and Kurdistani, 2017). An obvious advantage of rock structures versus non-living, organic structures is the longer design life. If organic material is not always submerged, the structures will decay rapidly and may need to be replaced 
(NRCS, 1996). The estimated design life for woody structures ranges from 10 to 70 years (Thompson, 2002; Veller and Doyle, 2001).

Twenty woody revetment studies were found that have been published in the last 20 years and are summarized in table A13 in the Appendix. Most of the studies were conducted by environmental scientists $(60 \%)$ in North America $(75 \%)$. Field studies were most common $(80 \%$; fig. 11$)$, as modeling woody structures in a lab or numerically is difficult, given the nature of the structures. Although site-scale projects were most common, reach-scale projects were also common. Furthermore, most studies, except for the physical modeling studies, evaluated woody revetments in natural stream systems (i.e., meandering with mobile bed). Similar to other instream structures, bedload transport studies (90\%) were most common in woody revetment research, followed by studies evaluating bank erosion $(80 \%)$, hydraulics $(35 \%)$, and habitat (35\%) (fig. 5).

Multiple field monitoring studies have been conducted on assessing effectiveness of toe wood at reducing near-bank velocities and protecting streambanks from erosion. Niezgoda and Johnson (2006) showed numerically that toe wood could be effective at reducing bank erosion over the long run if installed with rock riprap banks. Dhital et al. (2013) also reported short-term field application success in Nepal. Dave and Mittlestet (2017) and Veller and Doyle (2001) assessed the ability of toe wood using coniferous trees placed parallel to the streambank in dissipating flow energy and inducing deposition. Although this type of woody revetment tends to be inexpensive, these structures were not found to be as cost-effective in reducing bank erosion as permeable spurs and toe rock on a stream in the Midwestern U.S. (Dave and Mittelstet, 2017). Furthermore, Veller and Doyle (2001) noted that the effectiveness of coniferous woody revetments improved with additional anchoring measures and streambank management techniques, such as bank shaping and vegetation planting. In fact, incorporating additional anchoring in woody revetment design was a key finding in numerous monitoring studies (D'Aoust and Miller, 2000; Miller and Kochel, 2013; Shields et al., 2003b, 2004, 2006, 2008; Veller and Doyle, 2001). D’Aoust and

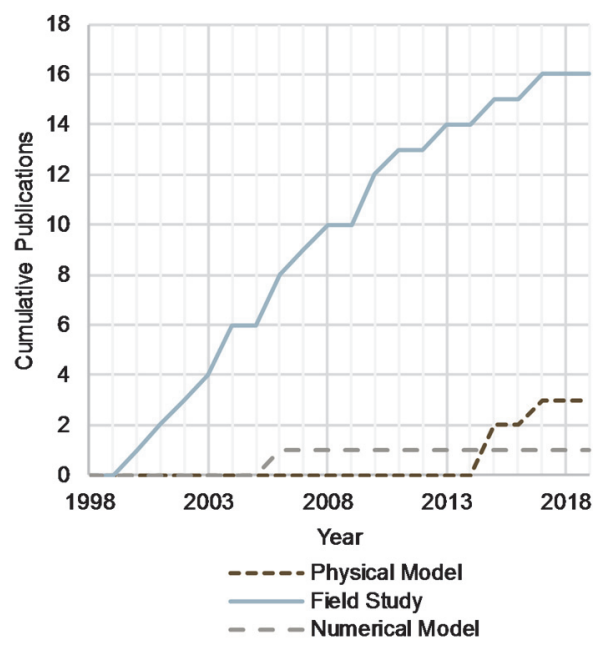

Figure 11. Temporal distribution of woody revetment studies.
Miller (2000) provided a theoretical approach for determining anchoring requirements for single and multiple log deflectors based on a factor of safety analysis, finding that the gravitational body force, the frictional force on the streambed, and the fluid drag force are the dominant forces acting on a log deflector. Alternatively Shields et al. (2004) found that the buoyancy force is often more prominent than the fluid drag force in low-gradient, sand-bed streams and recommended using both high-density wood and earth anchors in woody revetment designs. Shields et al. (2003b, $2004,2006,2008$ ) also noted that rapid vegetation establishment is critical for the site to remain stable after the woody revetments deteriorate.

In terms of log deflectors, Brooks et al. (2004) showed that reintroducing wood into a river that had been historically cleared, or de-snagged, of wood resulted in decreased bank erosion rates and improved in-stream sediment storage, bed morphology and material composition, and aquatic habitat. Furthermore, Pagliara et al. (2015a, 2015b) and Pagliara and Kurdistani (2017) demonstrated in a laboratory flume how log deflectors reduce bank erosion by shifting the scour hole away from the eroding bank. The researchers found that two log deflectors anchored by rock provided better protection against toe erosion than a single log deflector (Pagliara and Kurdistani, 2017). Additionally, tailwater depth, structure length, and angle all play a role in scour and deposition patterns around log deflectors (Pagliara et al., 2015a, 2015b). Based on these results, Pagliara et al. (2015a, 2015b) and Pagliara and Kurdistani (2017) developed empirical relationships to assist with predicting scour geometry near a log deflector.

As mentioned, $35 \%$ of studies evaluated the effects that woody revetments have on habitat. Sudduth and Meyer (2006) showed that toe wood increased the organic material and improved macroinvertebrate habitat in urban streams. Schiff et al. (2011) and Testa et al. (2010) reported similar observations, but only at site scale and not at reach scale, suggesting that a larger watershed issue may exist that has yet to be addressed. Similarly, Shields et al. (2003b, 2006) and Testa et al. (2010) noted temporarily improved site-scale habitat, which diminished after channel incision migrated into the site, ultimately causing the installed woody revetments to fail. Finally, Cooperman et al. (2007) were unable to decipher changes in habitat after installation of woody revetments and pointed to the lack of pre-construction habitat data to use for comparison.

\section{Streambank Management TeChNiQues}

Streambank management techniques include any inorganic or organic approach that in some way increases the shear strength of the streambank but does not necessarily reduce the shear stress applied to the streambank. Unlike instream structures, separating streambank management techniques is more difficult, as various approaches are often assessed in research projects. This is especially true for "soft" or bioengineering approaches. Therefore, the research summarized in this section is separated into "hardened" and "soft" streambank management techniques. Hardened streambanks include only fully hardened banks, from toe to top. Toe rock is included with the "soft" techniques, as it is 
often applied in combination with bank shaping, bench creation, and/or bioengineering approaches. Furthermore, woody revetments were included with the instream structure research summarized previously in this article, as these structures can act as both shear strength addition and flow deflection, depending on the design. Table A13 in the Appendix notes the woody revetment studies that assessed toe wood, or woody structures placed continuously along the streambank toe. For more information on toe wood studies, refer to the "Woody Revetments" section earlier in this article.

The following sections provide a summary of streambank management research and monitoring conducted from 1998 to 2019, divided into the two aforementioned categories. Again, some studies may appear in both categories if the researchers assessed both types of streambank management techniques.

\section{Hardened Streambank Management}

Probably the most obvious form of streambank management is the design and implementation of a rigid structure, such as a fully riprapped streambank, concrete retaining wall, or gabion basket wall (stackable, rectangular structures made of rock fill held together by a wire mesh). This option tends to be cost-prohibitive but, if designed correctly, will completely halt streambank erosion (Dave and Mittelstet, 2017). Twenty-one published studies were found on hardened streambanks since 1998 and are summarized in tables A14 through A16 in the Appendix. The majority of these studies were site-scale $(67 \%)$ with varying flows $(90 \%)$ conducted by environmental scientists $(62 \%)$ in North America (62\%). Field studies were the most popular form of assessment (52\%), followed by numerical models (33\%) and physical models (14\%), as shown in figure 12 .

Because the purpose of hardened banks is to stop bank erosion, it is not surprising that $62 \%$ of studies evaluated their ability to achieve this objective. All bank erosion studies showed that hardened banks are effective at reducing or stopping bank erosion at the site of interest, if properly designed and maintained. However, other issues with this approach were identified. For example, field monitoring studies found that riprap banks can reduce or stop bank erosion

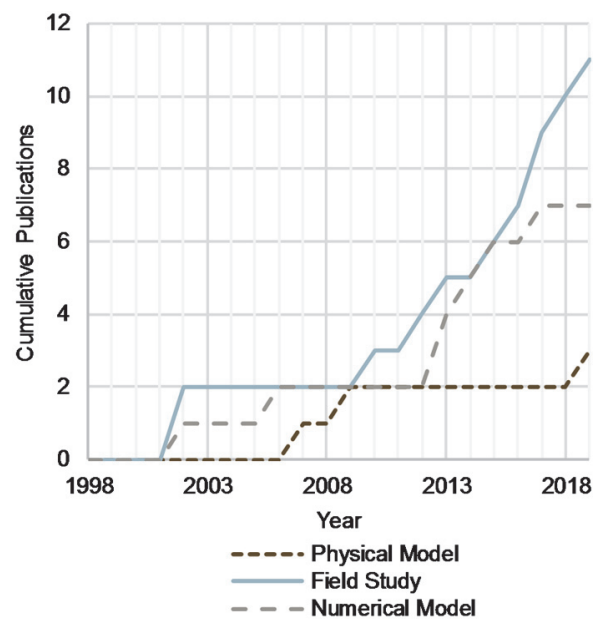

Figure 12. Temporal distribution of hardened bank studies. in streams in the Midwestern U.S. but were not as cost-effective as other streambank stabilization approaches (Bressan et al., 2014; Dave and Mittlestet, 2017). Site-scale to reach-scale impacts on morphology over the long run were also observed. Thompson (2002) and Thompson et al. (2016) showed that failing stabilization techniques could impact channel stability. In fact, based on a long-term study evaluating gabion walls on a stream in the northeastern U.S., Thompson et al. (2016) recommend not using gabion baskets for bank protection, as the mesh that contains the rock material can break, causing failure of the stabilization measure as well as an increase in sediment supply. Similarly, based on their long-term reach-scale simulation of bank protection measures that included riprap banks, Niezgoda and Johnson (2006) observed an increase in sediment deposition along the inside of the stabilized meander bed, causing an increase in applied shear stress on the riprap that would likely result in loss of rock and require long-term maintenance of the bank stabilization project. Finally, based on results from 1D lateral migration and sediment transport model simulations, riprap placement for bank stabilization was found to increase bed and/or bank erosion downstream of the stabilized site (Larsen and Greco, 2002; Reid and Church, 2015).

Because some studies showed that hardened banks may become less effective over time (Thompson, 2002; Niezgoda and Johnson, 2006), researchers proposed design improvements for these systems. Similar to the findings of Niezgoda and Johnson (2006), Roca et al. $(2007,2009)$ observed excessive scour near the toe of a concrete retaining wall used for bank stabilization. In an effort to reduce repair costs due to this observed scour, the researchers optimized the depth and width of a wall's footing. They found that a footing placed at one-third the maximum scour depth and with a width of two-thirds the maximum scour depth would reduce scour around the studied meander bend by $40 \%$ by weakening the secondary flow cell (Roca et al., 2007, 2009). However, the researchers noted that their findings are likely not replicable for all bend geometries and bed sediment and emphasized the importance of site-scale evaluations to properly design a footing for a vertical wall. In terms of improving riprap banks, researchers developed rock sizing equations for loose riprap banks based on a factor of safety equation (Froehlich, 2013) and for individually placed riprap banks based on expected flow conditions (Jafarnejad et al., 2019). In addition, Jafarnejad et al. (2017) developed a probabilistic assessment model to determine failure based on expected changes to flow and/or sediment transport conditions. Finally, Zhang et al. (2019) showed that using larger, more durable material in combination with other stabilization techniques, such as multiple rows of timber piles and vegetation, improved the effectiveness of riprap banks in reducing bank erosion.

Instead of quantifying bank erosion reduction, many research groups were more interested in the effects that hardened streambanks have on riparian and aquatic habitat $(59 \%)$. Both positive and negative effects on habitat were observed. In comparison to other soft streambank management techniques, riprap banks had the lowest plant species richness, plant functional diversity, and beetle diversity (Cavaille et al., 2013, 2015) and were also most susceptible 
to exotic plant invasion (Cavaille et al., 2013) in French and Swiss Alps streams. Based on these results, Cavaille et al. (2018) recommended not fixing a bank in place in order to maximize aquatic habitat diversification. Sudduth and Meyer (2006) also reported a decrease in organic habitat available to macroinvertebrates on riprap banks versus banks with live cuttings on urban streams in the southeastern U.S. Furthermore, Thompson (2002) found that riprap banks in combination with woody revetments offered less fish cover and riparian vegetation than natural banks on 40 to 60 year old projects. Similarly, through a numerical simulation, Jorgensen et al. (2013) showed that both the installation of riprap banks and human-induced climate change could reduce shallow water habitat for fish along a stream in the Pacific Northwest of the U.S.

Alternatively, positive effects on fish habitat at a local scale were reported for highly impacted streams with low aquatic habitat diversity. Although Massey et al. (2017) reported detrimental effects on instream cover and riparian vegetation following riprap installation on pristine streams in Canada, they observed increased bed slope, coarsened bed material, and thus improved fish habitat on disturbed, lowgradient streams near riprap banks. Similarly, Gidley et al. (2012) showed that riprap bank installation increased fish abundance and provided year-round habitat for fish in a stream in the Pacific Northwest. White et al. (2010) obtained similar results on a highly impacted stream in the Midwestern U.S., showing that mean fish species diversity and richness were significantly higher near banks stabilized with riprap versus natural banks.

\section{Soft Streambank Management}

The remainder of the streambank management techniques, including toe rock, bank shaping, bankfull bench, and vegetation and bioengineering, are summarized in this section. Rock riprap placed at the toe of a streambank, often called toe rock (figs. $1 \mathrm{~b}$ and $1 \mathrm{c}$ ), protects against fluvial erosion and loss of basal support (Lagasse et al., 2009; Shields et al., 1998b). Toe rock also adds weight to the bottom of the streambank, counteracting the gravitational force that may be acting on a streambank, and may prevent rotational failure. Other names include longitudinal peaked stone toe protection (LPSTP) and longitudinal toe dikes.

Streambank shaping (figs. $1 \mathrm{~b}$ and $1 \mathrm{c}$ ) flattens the slope and increases the critical bank height, or the maximum height of the bank that is not susceptible to bank erosion due to mass wasting. Although bank saturation can reduce bank stability, even on a shaped streambank, this technique reduces the likelihood of failure due to mass wasting (Simon and Rinaldi, 2000). Banks are typically shaped to a maximum slope of 2H:1V (NRCS, 2005).

Alternative ways to reduce bank height include infilling the channel, if it is incised, or adding a low-lying bench. Infilling can be accomplished either manually or with the installation of downstream grade control that promotes channel aggradation (Simon and Rinaldi, 2000; Thorne, 1999). Although bank erosion from mass wasting and geotechnical failure may decrease with aggradation, lateral migration from fluvial erosion might increase as the stream adjusts its slope (Thorne, 1999). Alternatively, adding a low-lying or bankfull bench (fig. 1f) may reduce the bank height subject to fluvial erosion and mass wasting and let the vertical bank behind the bench flatten over time (Thorne, 1999). A bench can also decrease applied shear stress by allowing high-flow events to spread over a floodplain (Rosgen, 1996; Simon et al., 2000).

There are a variety of bioengineering streambank management techniques that incorporate riparian plants (Gray and Sotir, 1996; NRCS, 1996). A detailed list of techniques is not provided in this review, but these techniques are usually placed on a shaped streambank to add streambank roughness and increase shear strength by providing tensile strength from root networks and increasing streambank drainage (Gray and Sotir, 1996; NRCS, 1996; Watson et al., 1997). In addition to providing structure to the streambank, established vegetation also provides an array of riparian ecosystem benefits (Cavaille et al., 2013, 2015, 2018). As mentioned previously, bioengineering is the oldest streambank stabilization technique (Evette et al., 2009).

The simplest form of bioengineering is the unsystematic planting of riparian plant species on a stabilized streambank, such as native riparian trees or dormant cuttings (also known as live stakes). Other examples of bioengineering techniques that are discussed in this section are timber piles, live fascines, brush mattresses, willow spiling, vegetated geogrids, and crib walls. A brief description of each is provided below. Additional techniques are described by Gray and Sotir (1996) and NRCS (1996).

Live stakes incorporate the use of dormant cuttings of a riparian woody species' trunk (e.g., willow, sycamore) that are manually placed into the phreatic zone of a streambank, where the cuttings eventually sprout roots and begin to grow (Watson et al., 1997). They can be placed sporadically or in rows, also known as brush layers (Frothingham, 2008). Timber piles function similar to live stakes except that they do not grow over time and only provide temporary roughness until vegetation is established (Zhang et al., 2019). Live fascines are long, circular bundles of dormant cuttings (Li et al., 2006), and wattles or coir rolls are rolls of geotextile fabrics (Frothingham, 2008), both of which can be placed on top or in trenched rows along the contour of an angled streambank. Brush mattresses consist of dormant cuttings either placed on top or trenched into an angled streambank to provide full coverage (Li et al., 2006). Willow spiling, a technique common in European countries, is similar to brush mattresses except that it is used on actively eroding streambanks and includes vertical cuttings woven with additional horizontal cuttings (Anstead et al., 2012). Erosion control blankets are geotextile fabrics stapled or staked to the streambank (Frothingham, 2008). A vegetated geogrid is a series of soil lifts wrapped with geotextile that rebuilds a streambank at a flatter slope and is typically planted with live stakes (Gray and Sotir, 1996). Finally, a crib wall is a wooden structure placed at the bottom of an eroding streambank that is filled with soil and planted with vegetation (Krymer and Robert, 2014).

Twenty-eight studies were found on soft streambank management techniques published over the last 20 years and are summarized in table A17 in the Appendix. Most of the studies were conducted in the field (79\%) by environmental scientists $(82 \%)$ in North America (61\%), observing site- 
scale effects $(93 \%)$ of techniques under varying flow conditions $(85 \%)$. Of the four soft engineering techniques mentioned, vegetation/bioengineering (64\%) and toe rock (54\%) have been the most studied, followed by bank shaping (29\%). Only one physical modeling study (fig. 13) was found on bioengineering, toe rock, and bank shaping (Recking et al., 2019). Furthermore, no studies were found that (1) explicitly stated that a bankfull bench was installed as part of the streambank stabilization project or (2) assessed projects at river scale. Finally, of the numerical modeling studies conducted, the majority were 1D simulations using publicly available models.

Unlike the previously mentioned streambank stabilization techniques, effect on bank erosion was the most popular research objective (57\%), followed by habitat effects (54\%), bedload effects (29\%), and hydraulic effects (25\%, fig. 5). Although some researchers reported properties of the channel (e.g., width-to-depth, slope, etc.) and techniques (e.g., height, bank angle) studied, many did not, making it difficult to compare studies. Further, toe rock descriptions vary considerably, as some studies mentioned height based on flow depth (Elhakeem et al., 2017) or bank height (Simon et al., 2009; Simon and Steineman, 2000), while others mention application rate (Shields et al., 1998a, 2000). Finally, the maximum constructed bank angle assessed and reported was 2H:1V (Holmes et al., 2019; Simon and Steinman, 2000; Veller and Doyle, 2001), while the minimum was $3 \mathrm{H}: 1 \mathrm{~V}$ (Enlow et al., 2018).

As mentioned, the majority of research groups evaluated the effectiveness of soft streambank management techniques in reducing bank erosion, often comparing and/or incorporating multiple techniques. Interestingly, the majority of the studies did not agree on the combination of techniques that was most effective. The following provides a summary of the techniques that were found to be most effective in reducing bank erosion:

- Bank shaping, vegetation, and grade control (Enlow et al., 2018).

- Bank shaping, toe rock, and vegetation (Recking et al., 2019; Simon et al., 2009).

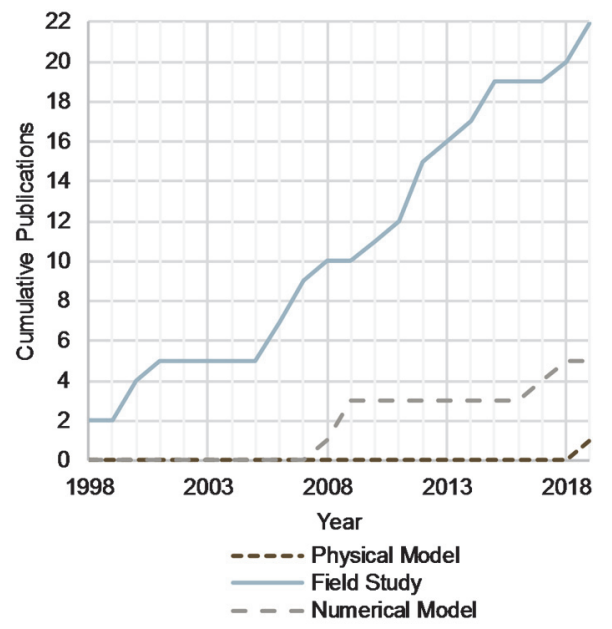

Figure 13. Temporal distribution of soft engineering streambank management studies, including toe rock, vegetation/bioengineering, bank shaping, and bankfull bench studies.
- Bank shaping, toe rock, vegetation, and woody revetments (Veller and Doyle, 2001).

- Bendway weirs and toe rock (Acharya and Gautam, 2012).

- Riprap, timber piles, and vegetation (Zhang et al., 2019).

- Toe rock and vegetation/brush mattresses (Frothingham, 2008).

- Vegetation using bioengineering approaches (Dhital et al., 2013; Li et al., 2006; Simon and Steineman, 2000).

Alternatively, Elhakeem et al. (2017) showed that rock flow deflectors were more effective than toe rock at reducing bank erosion by inducing deposition in the near-bank region.

Vegetation was incorporated in all but one (Acharya and Gautam, 2012) of the identified effective streambank management techniques listed above. Establishing vegetation through various bioengineering approaches has been recently assessed. Some researchers evaluated the survival of live stakes that were incorporated into bioengineering techniques. Anstead and Boar (2010) and Anstead et al. (2012) recommended special care of bioengineering techniques incorporating willow in the early years, such as removing cattle from the site, watering, and replanting when necessary. Anstead and Boar (2010), Anstead et al. (2012), and Pezeshki et al. (2007) also recommended being mindful of site selection, as incising streams may result in structure failure (Anstead et al., 2012), and banks composed of coarser materials require more watering or deeper planting into the groundwater table (Anstead et al., 2012; Pezeshki et al., 2007). Pezeshki et al. (2007) found that black willow cuttings did best in silty-textured banks. Frothingham (2008) evaluated the ability of several bioengineering approaches, such as wattles, coir logs, live fascines, brush mattresses, brush layering, live stakes, and erosion control blankets, to withstand applied velocity and shear stress. Frothingham (2008) found that brush mattresses, in combination with toe rock, were best able to withstand applied velocity and shear stress on eroding streambanks along a stream in the northeastern U.S.

In terms of improving design of bioengineering approaches, Bischetti et al. (2010) integrated live fascine design parameters, such as stems per meter, fascine diameter, and distance between fascines, into a slope stability model. Krymer and Robert (2014) evaluated several crib wall projects, identifying wall design parameters, such as height, location, and vegetation type and placement, and site characteristics, such as stream power, bank sediment composition, and planform, as important factors that affect long-term crib wall stability. Additionally, Petrone and Petri (2008) noted the importance of determining the best native species to use in bioengineering practices. While these studies certainly help in the design and selection of bioengineering techniques, other bioengineering techniques exist that have yet to be evaluated.

Toe rock was also found to be effective in reducing streambank erosion. Simon et al. (2009) provided the most support for this technique, showing that incorporation of toe protection has potential to reduce sediment loads from 
streambank erosion by $69 \%$ to $100 \%$ on streams in the Lake Tahoe watershed in the western U.S. The researchers stressed the importance of, at minimum, protecting the streambank's toe from erosion. However, Shields et al. (2000) observed an increase in flow velocities in reaches with only toe rock installed. This increase in velocity is expected to increase scouring near the vicinity of the toe rock, but no studies were found that quantified this effect. Alternatively, several researchers recommended using toe rock or other forms of toe protection in combination with additional stabilization techniques, such as flow deflectors, woody revetments and bioengineering, to guarantee long-term project success (Acharya and Gautam, 2012; Anstead and Boar, 2010; Frothingham, 2008; Recking et al., 2019; Shields et al., 2000; Veller and Doyle, 2001).

Effects on habitat were also of interest when assessing soft streambank management techniques, with most studies finding positive effects on habitat conditions. Cavaille et al. $(2013,2015,2018)$ investigated animal habitat and riparian vegetation across riprap banks, toe rock and vegetated banks, bioengineered banks using crib walls and live fascines, and natural banks on streams in the French and Swiss Alps. Treated banks using both toe rock and vegetation had the greatest plant functional diversity (Cavaille et al., 2013, 2015), while bioengineered banks showed greater macroinvertebrate biodiversity than any other treatment type (Cavaille et al., 2018). Two other research groups obtained similar results, reporting improved macroinvertebrate habitat following installation of bioengineering practices $(\mathrm{Li}$ et al., 2006), as well as other stabilization measures that incorporated woody revetments, rock vanes, and vegetation (Schiff et al., 2011). However, Schiff et al. (2011) did not observe this same positive effect on macroinvertebrate habitat at reach scale, suggesting that watershed-scale issues may dampen these effects. Shields et al. (1998a, 1998b, 2000) and Gidley et al. (2012) reported improvement in fish habitat following installation of toe rock and vegetation, as well as bendway weirs (Shields et al., 1998a, 1998b, 2000), on severely impacted streams in the U.S. Finally, Sudduth and Meyer (2006) and Cooperman et al. (2007) reported an increase in organic material habitat on banks stabilized with bioengineering.

Holmes et al. (2019) was the only study to report reduced habitat conditions for predator/prey populations following bank shaping on a stream in New Zealand. This reduction was assumed to be caused by a temporary increase in fine sediment deposition at the site due to construction activities. Fortunately, aquatic communities returned to pre-construction conditions three years after bank shaping occurred (Holmes et al., 2019).

\section{STREAMBANK STABILIZATION RESEARCH NEEDS}

Over 140 published, peer-reviewed journal articles on the physical and biological effects of streambank stabilization systems are cited in this article, but research needs still exist. Two common research needs were identified among all the streambank stabilization techniques: (1) assess the spatiotemporal variability in hydraulics, sediment transport, bank erosion, and habitat induced by streambank stabilization techniques, and (2) improve numerical simulation and system design.

These common research needs are discussed further in the following sections. In addition, research needs specific to a particular streambank stabilization technique are presented. Finally, this section provides suggestions for standard reporting in future streambank stabilization publications.

\section{RESEARCH NEED 1: ASSESS SPATIOTEMPORAL VARIABILITY INDUCED BY STREAMBANK STABILIZATION TECHNIQUES}

An intriguing finding of this review is that the effect on streambank erosion of streambank stabilization techniques was not the most commonly studied physical effect across all the studies. While this observation may be skewed by the disproportionate number of instream structure studies $(80 \%$ of 146) that have a large effect on sediment transport, assessing the ability of all streambank stabilization techniques to reduce bank erosion should be a top priority. As noted by several research groups, some techniques may be more effective than others in the long run (e.g., Bressen et al., 2014; Dave and Mittlestet, 2017; Frothingham, 2008). In addition to the long-term effectiveness, various technique configurations (Bhuyian et al., 2010; Cunningham and Lyn, 2016; Elhakeem et al., 2017; Khosronejad et al., 2017; Jamieson et al., 2013a, 2013b; Recking et al., 2019; Teraguchi et al., 2011) as well as flow (Abad et al., 2008; Biron et al., 2004), sediment (Buchanan et al., 2014), and boundary conditions (Karki et al., 2018; Wu et al., 2005) can affect overall bank erosion mitigation. While bank erosion was assessed with an erodible bank in a laboratory setting by a few researchers (e.g., Cunningham and Lyn, 2016; Dey et al., 2017; Jamieson et al., 2013a, 2013b) or by applying 1D or 2D lateral erosion models (e.g., Enlow et al., 2018; Larsen and Greco, 2002; Niezgoda and Johnson, 2006; Simon et al., 2009), many physical and numerical studies only evaluated nearbank scour depth and/or velocity, shear stress, and secondary currents as an indication of bank erosion reduction via fluvial erosion. As pointed out by Simon et al. (2000), many physical processes (e.g., fluvial erosion, subaerial processes, and mass wasting) affect bank erosion rates, and dominant processes can change over time (Couper, 2004). Therefore, it is imperative that dominant bank erosion processes are included in future streambank stabilization research.

In addition to evaluating the site-scale effects that streambank stabilization techniques have on bank erosion, continued understanding of a broader spatial scale (reach, river, and/or watershed scale) and longer temporal scale is critical for long-term project success (Anstead et al., 2012; Bhuyian et al., 2009; Brooks et al., 2004; Buchanan et al., 2014; Cavaille et al., 2018; Cooperman, 2007; Enlow et al., 2018; Gidley et al., 2012; Khosronejad et al., 2017; Larsen and Greco, 2002; Li et al., 2018; Miller and Kochel, 2010, 2013; Shih et al., 2008; Thompson, 2002; Veller and Doyle 2001; White et al., 2010; Wu et al., 2005). The best way to assess the spatiotemporal variability of streambank stabilization projects is through long-term field studies, as they provide 
the most accurate assessment of how techniques function in a natural setting. Including multiple sites (Massey et al., 2017) and obtaining data needed for before-after-control-impact (BACI) studies (Cooperman et al., 2007) will enhance conclusions drawn from field studies.

The vast majority of studies reviewed here were conducted at the site scale. While most streambank stabilization projects only occur along a small section of a stream (e.g., a single meander bend), researchers noted the importance of understanding the possible reach-scale and river-scale effects on channel stability (Anstead et al., 2012; Bhuyian et al., 2009; Brooks et al., 2004; Buchanan et al., 2014; Cavaille et al., 2018; Cooperman et al., 2007; Enlow et al., 2018; Florsheim et al., 2008; Gidley et al., 2012; Khosronejad et al., 2013; Larsen and Greco, 2002; Massey et al., 2017; Miller and Kochel, 2013; White et al., 2010; Wu et al., 2005). For example, scour prediction is an important design consideration for instream structures, hardened banks, and streambank toe protection, as excessive scour can cause structures to fail. As presented in the "Recent Research and Monitoring of Streambank Stabilization" section, scour hole characteristics produced by impermeable instream structures have been studied and quantified extensively to assist with instream structure design. In contrast, deposition induced by instream structures, especially impermeable structures, has not been evaluated to the same extent. This is likely because many of the researchers conducting scour studies were engineers who were most interested in protecting against structure failure and/or relocating the thalweg. Generally, localized deposition does not pose a threat and is often assumed to have a positive effect. However, some researchers noted that the depositional features created by the increase in localized scour at the site may have reach-scale effects, as these features can move slowly downstream and potentially increase streambank erosion downstream (Bhuyian et al., 2009; Khosronejad et al., 2013). Furthermore, Bhuyian et al. (2009) and Giri et al. (2003) noted that a change in the velocity distribution could occur at reach scale, following installation of structures, which could also affect bank erosion downstream of the site. Finally, Wu et al. (2005) noted that continued installation of bank erosion measures can shift streams from a braided geomorphic form to confined and meandering. Florsheim et al. (2008) described this shift as unintentional channelization that could have both physical and biological impacts. Therefore, continued evaluation of hydraulic and bedload patterns at reach to river scale or at watershed scale should be conducted for all configurations of stabilization techniques and flow, sediment, and boundary conditions (Azinfar and Kells, 2007; Biron et al., 2004; Buchanan et al., 2014; Giri et al., 2003; Jia et al., 2005; Karki et al., 2018; Khosronejad et al., 2013; Koken and Constantinescu, 2008b; Kuhnle et al., 2008; Rahman and Murmato, 1999; Tritthart et al., 2009).

Advancing the understanding of the spatiotemporal variability in streambank stabilization performance also requires considering the ultimate cause of streambank instability and the channel's current evolutionary stage (Enlow et al., 2018; Florsheim et al., 2008; Rosgen, 1996; Wohl et al., 2005). However, these factors have been largely ignored, or at least not reported, in the streambank stabilization literature to date. It has been suggested that failed streambank stabilization techniques may have been unsuccessful because of larger watershed-scale or stream-scale issues (Florsheim et al., 2008; Schiff et al., 2011; Simon and Steinman, 2000; Sudduth and Meyer, 2006; Testa et al., 2010) that should have been addressed first. Furthermore, stream reaches in the degrading phase of channel evolution models are extremely susceptible to structure failure if grade control measures are not placed (Enlow et al., 2018; Shields et al., 1998b).

A key design question related to the spatiotemporal variability in streambank stabilization performance is: In what situations are certain streambank stabilization techniques most appropriate? Very few studies identified specific stream types where streambank stabilization techniques work to achieve project objectives. Of the studies that did, their potentially useful observations include:

- Adding structure (e.g., instream structures, toe rock/wood) to bioengineering techniques can buy time for vegetation establishment (Anstead and Boar, 2010; Bhuyian et al., 2010; Buchanan et al., 2014; Krymer and Robert, 2014; Li and Eddleman, 2002; Simon and Steinman, 2000).

- Instream structures are more susceptible to failure in streams with width-to-depth ratios of 10 or less (Radspinner et al., 2010)

In terms of the stream width observation by Radspinner et al. (2010), the width-to-depth ratio could be related to the stream's channel evolution stage, as wide and shallow streams tend to be aggradational, while narrow and deep streams tend to be degradational (Simon and Hupp, 1986). While the survey by Radspinner et al. (2010) included evaluation of grade control structures, it was not clear if failing instream structures on narrow and deep streams also incorporated grade control measures, if deemed necessary. However, Miller and Kochel $(2010,2013)$ noted that instream structures, such as rock vanes, failed even on streams where the bed was stabilized. These observations provide additional evidence that a need exists to determine what techniques to use in certain channel geomorphic conditions.

\section{RESEARCH NEED 2: IMPROVE NUMERICAL SIMULATION AND SYSTEM DESIGN}

Numerical modeling studies were the least common study type among the recent literature on streambank stabilization techniques. If the overall goal is to improve the design of streambank stabilization techniques, this needs to change. To date, streambank stabilization systems continue to be designed by experienced professionals, generally using an array of rules-of-thumb provided by design manuals. As noted by several researchers, these design guidelines have limitations and are only as good as the model or site that they came from (Fox et al., 2005; Kinzli and Thornton, 2010; Matsuura and Townsend, 2004; Rahman and Muramato, 1999; Scurlock et al., 2015). As data collection and computational technologies continue to improve, numerical models should replace or enhance these guidelines (Abad et al., 2008; Elawady et al., 2001; Enlow et al., 2018; Khosronejad et al., 2017; Minor et al., 2007; Pandey et al., 2016; Zhang and Nakagawa, 2009), allowing designers to come up with unique solutions that best fit the varying flow and sediment 
regime, as well as the boundary conditions of a specific site, reach, and/or river (Bhuyian et al., 2009; Biron et al., 2004; Gupta et al., 2010; Karki et al., 2018; Roca et al., 2007, 2009; Voisin and Townsend, 2002).

Determining what model dimension, or level of complexity, to use for system design depends on the project's objectives, expected design life, and budget, as increasing complexity means increased data requirements and computational time and, as a result, increased cost (Duan and Nanda, 2006; Elhakeem et al., 2017; Enlow et al., 2018). Given the need to understand the reach-scale to watershed-scale effects of stabilization systems over a longer time scale, 2D and preferably $3 \mathrm{D}$ models should provide the most accurate results of velocity distribution, sediment transport, and bed evolution, if properly calibrated (Bhuyian et al., 2009; Khosronejad et al., 2017; McCoy et al., 2007). However, as the spatial and/or temporal scale becomes more expansive, obtaining results from higher-dimension models may not be feasible. Therefore, a need exists to assist designers in selecting the appropriate model to use based on project constraints.

If $3 \mathrm{D}$ modeling is identified as the best approach, the VSL3D code developed by Khosronejad et al. (2013, 2014a, $2014 b, 2017$ ) has the ability to represent varying field conditions and has been used to design several instream structures, such as bendway weirs, rock vanes, and grade control structures. However, this 3D model does not simulate bank erosion. In fact, none of the cited 3D models have the ability to simulate bank erosion, which remains a major research gap in 3D geomorphic modeling. Furthermore, the VSL3D code is apparently not publicly available for design applications. This was a common observation, as several of the applied numerical models were custom-built models that were not easily accessible to the public. Therefore, it is recommended that custom-built numerical models that have been successfully applied in the design of multiple streambank stabilization techniques become more readily available for outside application.

Alternatively, Duan and Nanda (2006) and Elhakeem et al. (2017) suggested putting more effort into 2D models for practical design purposes, as 2D models are more cost-effective (e.g., require less data collection for calibration, computationally easier to run) and have been employed to model bank erosion (Niezgoda and Johnson, 2006). Other types of numerical models that may be useful for stream scientists, designers, and planners are climate (Jorgensen et al., 2013) and/or 1D channel migration models (Enlow et al., 2018; Larsen and Greco, 2002; Simon et al., 2009).

Results from physical models and field studies can and should be used to calibrate and improve numerical model simulations (Dey et al., 2017; Elawady et al., 2001; Giri et al., 2004; Sinha and Marelius, 2000). Ideally, a designer employing a numerical model would calibrate the model using data collected at the site of interest. Therefore, sensitivity analyses should be conducted on all numerical models to determine which input parameters have the greatest effects on the model results (Nagata et al., 2005). This knowledge would enable designers and researchers to collect the data most pertinent to calibration. Sensitivity analyses have already been conducted on bank erosion numerical models, such as BSTEM (Lammers et al., 2016) and CONCEPTS (Langendeon and Simon, 2008). If funds do not allow for site-specific data collection to calibrate numerical models, results from past physical model and field studies can be applied, if they share similar characteristics of the site of interest. This further justifies the need for continued spatiotemporal evaluation, through both physical models and fields studies, of streambank stabilization techniques. However, if physical models are used to calibrate numerical models, Khosronejad et al. (2013) recommended that future laboratory models use materials and dimensions typical of real streambank stabilization techniques (i.e., using rock or wood), as the effects induced by the complex nature of real structures is still lacking in the literature.

\section{Additional Specific Research NeEdS}

In addition to the two research needs identified in the previous sections, table 2 provides a summary of research needs for specific streambank stabilization techniques highlighted in the "Recent Research and Monitoring of Streambank Stabilization" section, as well as techniques identified by other researchers (as cited in table 2).

\section{RECOMMENDATIONS FOR STANDARD REPORTING IN STREAMbank STABILIZATION RESEARCH}

Three discoveries made this review challenging and, at times, frustrating: (1) the varying structure nomenclature, (2) the lack of detail on streambank stabilization techniques and channels, and (3) the disconnect between research scientists, research engineers, and practitioners. In terms of structure nomenclature, future streambank stabilization publications should use the same nomenclature presented and defined in this review. This will help scientists and engineers identify research needs for specific techniques and reduce unintended duplication, which unfortunately has happened over the last 20 years. Furthermore, as noted several times throughout this review, the characteristics of the stabilization technique (e.g., shape, angle, height, length, etc.) and of the channel (e.g., slope, width, etc.) were often omitted from the published results. As a result, placing studies in proper categories and comparing results across studies were extremely

Table 2. Additional research needs for streambank stabilization techniques.

\begin{tabular}{cl}
\hline Technique & Research Needs \\
\hline Impermeable spurs & Improve rock sizing criteria (Abt et al., 2016). \\
\hline Bendway weirs & No identified additional needs. \\
\hline Rock vanes & Improve rock sizing criteria (Abt et al., 2016). \\
\hline Permeable spurs & Assess habitat effects. \\
\hline Submerged vanes & Assess habitat effects; \\
& Determine strength and number of vortices around \\
& vanes (Marelius and Sinha, 1998). \\
\hline Woody revetments & No identified additional needs. \\
\hline Hardened streambanks & Test scour effects of retaining wall flexible footings \\
& (Roca et al., 2009). \\
\hline Toe rock & Conduct scour analyses; \\
& Improve rock sizing criteria (Abt et al., 2016; \\
& Frothingham, 2008). \\
\hline Bank shaping & No identified additional needs. \\
\hline Bankfull bench & Conduct any type of study on this technique. \\
\hline Vegetation and & Examine the effects of all types and variations of \\
Bioengineering & bioengineering approaches; \\
& Identify the best native species to incorporate into \\
& bioengineering practices across the globe \\
(Petrone and Preti, 2008).
\end{tabular}


difficult. Additionally, results from physical modeling and field studies that omit these details may be useless to designers attempting to calibrate numerical modeling tools from past studies. This leads to the final frustration: the lack of communication between research scientists, research engineers, and practitioners.

Several field studies conducted by environmental scientists omitted structure details and often used vague terms to describe techniques. Could this mean that researchers and practitioners are not working together to advance streambank stabilization design? This apparent disconnect between researchers and practitioners was not limited to scientists; several studies led by engineers tested structures that were (1) sized, placed, and configured in a way that is rarely, if ever, used in practice and/or (2) in channel configurations that rarely exist in the natural world. An example of this disconnect comes from comparing the survey results of stream restoration designers reported by Radspinner et al. (2010) and the structure and channel configurations of the physical and numerical models presented in this review. The survey found that instream structures, such as impermeable spurs, bendway weirs, and rock vanes, appear to be more prone to failure on streams with a single structure and/or with low width-to-depth ratios. However, many physical and numerical modeling studies on impermeable spurs and bendway weirs have focused on evaluating only a single structure on channels with low width-to-depth ratios.

Finally, when reviewing the expertise of research teams, a combination of research scientists and research engineers is rare. In the future, the objectives of all streambank stabilization projects should include reducing accelerated bank erosion and either (1) improving habitat for native species or (2) leaving it unchanged. To be successful, this approach would require multidisciplinary teams of research engineers, environmental scientists, and practitioners.

\section{CONCLUSION}

Streambank stabilization consists of a single technique or a system of techniques that maximize localized streambank shear strength and/or minimize the forces acting on a streambank with the intent of halting or minimizing lateral retreat. Streambank stabilization systems are the oldest and arguably the most common river management technique used by practitioners. This review identified eleven general streambank stabilization techniques: impermeable spurs, bendway weirs, rock vanes, permeable spurs, submerged vanes, woody revetments, hardened streambank, toe rock, bank shaping, bankfull bench, and vegetation/bioengineering. A total of 146 peer-reviewed journal articles, published since 1998, were found pertaining to these techniques. Of those studies, bendway weir research has been the most common, while permeable spur research has been the least common. Overall, physical models were the most common type of study, followed by field studies and numerical models, although numerical modeling studies have become more common over the last 15 years. Furthermore, instream structures were often evaluated using physical models, while streambank management techniques were assessed primarily in the field.
The most commonly studied physical effect of streambank stabilization was not the effect on bank erosion but rather the effect on sediment transport, especially bedload transport. However, this was likely skewed due to the uneven distribution of instream structure studies ( $80 \%$ of 146 studies) versus streambank management techniques (29\%).

Based on this review, two research needs were identified among all the streambank stabilization techniques: (1) assess the spatiotemporal variability in hydraulics, sediment transport, bank erosion, and habitat induced by streambank stabilization techniques, and (2) improve numerical simulation and system design. The spatiotemporal variability of techniques should be further evaluated to (1) measure the effect of streambank stabilization techniques on local bank erosion rates over time, (2) understand the reach-scale to river-scale effects on hydraulics, sediment transport, bank erosion rates, and habitat, and (3) determine the environmental contexts in which streambank stabilization techniques are most effective. Improving numerical models should be the primary focus of future streambank stabilization research so that designs can be developed based on specific project site conditions, such as the stream's flow distribution and sediment regime, rather than relying solely on a set of design guidelines. Developing designs using calibrated numerical simulations should reduce unintended reach-scale to riverscale impacts on channel stability. In addition, a list of research needs for specific stabilization techniques was provided.

In an effort to advance the science and practice of streambank stabilization, it is recommended that future streambank stabilization research publications (1) use consistent nomenclature as presented in this review, (2) provide details about the characteristics of the techniques applied and the channel studied, (3) justify the experimental setup, and (4) explain how the research will improve design.

\section{ACKNOWLEDGEMENTS}

The author would like to thank Dr. Trisha Moore and Dr. Tim Keane, as well as the reviewers, for their assistance in improving this review article.

\section{REFERENCES}

Abad, J. D., Rhoads, B. L., Guneralp, I., \& Garcia, M. H. (2008). Flow structure at different stages in a meander-bend with bendway weirs. J. Hydraul. Eng., 134(8), 1052-1063. https://doi.org/10.1061/(ASCE)0733-9429(2008)134:8(1052)

Abt, S. R., Michael Scurlock, S., Thornton, C. I., Cox, A. L., \& Holste, N. J. (2016). Bendway weir riprap sizing criteria. J. Hydraul. Eng., 142(12), 06016018. https://doi.org/10.1061/(ASCE)HY.1943-7900.0001209

Acharya, K., \& Gautam, M. (2012). Evaluation of bendway weir bank stabilization techniques for stream restoration. Intl. J. River Basin Mgmt., 10(2), 171-176. https://doi.org/10.1080/15715124.2012.679737

Anstead, L., \& Boar, R. R. (2010). Willow spiling: Review of streambank stabilisation projects in the U.K. Freshwater Rev., 3(1), 33-47. https://doi.org/10.1608/FRJ-3.1.2

Anstead, L., Boar, R. R., \& Tovey, N. K. (2012). The effectiveness of a soil bioengineering solution for river bank stabilisation during flood and drought conditions: Two case studies from East 
Anglia. Area, 44(4), 479-488. https://doi.org/10.1111/j.14754762.2012.01132.x

Azinfar, H., \& Kells, J. A. (2007). Backwater effect due to a single spur dike. Canadian J. Civil Eng., 34(1), 107-115. https://doi.org/10.1139/106-117

Belmont, P., Gran, K. B., Schottler, S. P., Wilcock, P. R., Day, S. S., Jennings, C., ... Parker, G. (2011). Large shift in source of fine sediment in the upper Mississippi River. Environ. Sci. Tech., 45(20), 8804-8810. https://doi.org/10.1021/es2019109

Bernard, J. M., \& Tuttle, R. W. (1998). Stream corridor restoration: Principles, processes, and practices. Proc. Wetlands Engineering and River Restoration Conf. (pp. 320-325). Reston, VA: ASCE. https://doi.org/10.1061/9780784403822

Bhuiyan, F., Hey, R. D., \& Wormleaton, P. R. (2009). Effects of vanes and $\mathrm{W}$-weir on sediment transport in meandering channels. J. Hydraul. Eng., 135(5), 339-349. https://doi.org/10.1061/(ASCE)0733-9429(2009)135:5(339)

Bhuiyan, F., Hey, R. D., \& Wormleaton, P. R. (2010). Bankattached vanes for bank erosion control and restoration of river meanders. J. Hydraul. Eng., 136(9), 583-596.

https://doi.org/10.1061/(ASCE)HY.1943-7900.0000217

Biron, P. M., Robson, C., Lapointe, M. F., \& Gaskin, S. J. (2004). Deflector designs for fish habitat restoration. Environ. Mgmt., 33(1), 25-35. https://doi.org/10.1007/s00267-003-3080-9

Bischetti, G. B., Chiaradia, E. A., D'Agostino, V., \& Simonato, T. (2010). Quantifying the effect of brush layering on slope stability. Ecol. Eng., 36(3), 258-264. https://doi.org/10.1016/j.ecoleng.2009.03.019

Bressan, F., Wilson, C. G., \& Papanicolaou, A. N. T. (2014). Improved streambank countermeasures: The Des Moines River (USA) case study. Intl. J. River Basin Mgmt., 12(1), 69-86. https://doi.org/10.1080/15715124.2014.882844

Brooks, A. P., Gehrke, P. C., Jansen, J. D., \& Abbe, T. B. (2004). Experimental reintroduction of woody debris on the Williams River, NSW: geomorphic and ecological responses. River Res. Appl., 20(5), 513-536. https://doi.org/10.1002/rra.764

Buchanan, B. P., Nagle, G. N., \& Walter, M. T. (2014). Long-term monitoring and assessment of a stream restoration project in central New York. River Res. Appl., 30(2), 245-258. https://doi.org/10.1002/rra.2639

Burele, S. A., Gupta, I. D., Singh, M., Sharma, N., \& Ahmad, Z. (2012). Experimental study on performance of spurs. ISH J. Hydraul. Eng., 18(3), 152-161. https://doi.org/10.1080/09715010.2012.695446

Cavaille, P., Dommanget, F., Daumergue, N., Loucougaray, G., Spiegelberger, T., Tabacchi, E., \& Evette, A. (2013). Biodiversity assessment following a naturality gradient of riverbank protection structures in French prealps rivers. Ecol. Eng., 53, 23-30. https://doi.org/10.1016/j.ecoleng.2012.12.105

Cavaille, P., Ducasse, L., Breton, V., Dommanget, F., Tabacchi, E., \& Evette, A. (2015). Functional and taxonomic plant diversity for riverbank protection works: Bioengineering techniques close to natural banks and beyond hard engineering. J. Environ. Mgmt., 151, 65-75. https://doi.org/10.1016/j.jenvman.2014.09.028

Cavaille, P., Dumont, B., Van Looy, K., Floury, M., Tabacchi, E., \& Evette, A. (2018). Influence of riverbank stabilization techniques on taxonomic and functional macrobenthic communities. Hydrobiologia, 807(1), 19-35. https://doi.org/10.1007/s10750-017-3380-3

Cooperman, M. S., Hinch, S. G., Bennett, S., Branton, M. A., Galbraith, R. V., Quigley, J. T., \& Heise, B. A. (2007). Streambank restoration effectiveness: Lessons learned from a comparative study. Fisheries, 32(6), 278-291. https://doi.org/10.1577/1548-8446(2007)32[278:srelfa]2.0.co;2
Couper, P. R. (2004). Space and time in river bank erosion research: A review. Area, 36(4), 387-403. https://doi.org/10.1111/j.00040894.2004.00239.x

Couper, P. R., \& Maddock, I. P. (2001). Subaerial river bank erosion processes and their interaction with other bank erosion mechanisms on the River Arrow, Warwickshire, U.K. Earth Surf. Proc. Landforms, 26(6), 631-646. https://doi.org/10.1002/esp.212

Cunningham, R. S., \& Lyn, D. A. (2016). Laboratory study of bendway weirs as a bank erosion countermeasure. J. Hydraul. Eng., 142(6), 1-21. https://doi.org/10.1061/(ASCE)HY.19437900.0001117

D’Aoust, S. G., \& Millar, R. G. (2000). Stability of ballasted woody debris habitat structures. J. Hydraul. Eng., 126(11), 810-817. https://doi.org/10.1061/(ASCE)0733-9429(2000)126:11(810)

Dave, N., \& Mittelstet, A. R. (2017). Quantifying effectiveness of streambank stabilization practices on Cedar River, Nebraska. Water, 9(12), 930. https://doi.org/10.3390/w9120930

Dehghani, A. A., Azamathulla, H. M., Hashemi Najafi, S. A., \& Ayyoubzadeh, S. A. (2013). Local scouring around L-head groynes. J. Hydrol., 504, 125-131. https://doi.org/10.1016/j.jhydrol.2013.09.020

Dey, L., Barbhuiya, A. K., \& Biswas, P. (2017). Experimental study on bank erosion and protection using submerged vane placed at an optimum angle in a $180^{\circ}$ laboratory channel bend. Geomorphology, 283, 32-40. https://doi.org/10.1016/j.geomorph.2017.01.022

Dhital, Y. P., Kayastha, R. B., \& Shi, J. (2013). Soil bioengineering application and practices in Nepal. Environ. Mgmt., 51(2), 354364. https://doi.org/10.1007/s00267-012-0003-7

Duan, J. G. (2009). Mean flow and turbulence around a laboratory spur dike. J. Hydraul. Eng., 135(10), 803-811. https://doi.org/10.1061/(ASCE)HY.1943-7900.0000077

Duan, J. G., \& Nanda, S. K. (2006). Two-dimensional depthaveraged model simulation of suspended sediment concentration distribution in a groyne field. J. Hydrol., 327(3), 426-437. https://doi.org/10.1016/j.jhydrol.2005.11.055

Duan, J. G., He, L., Fu, X., \& Wang, Q. (2009). Mean flow and turbulence around experimental spur dike. Adv. Water Resour., 32(12), 1717-1725. https://doi.org/10.1016/j.advwatres.2009.09.004

Elawady, E., Michiue, M., \& Hinokidani, O. (2000). Experimental study of flow behavior around submerged spur-dike on rigid bed. Proc. Hydraul. Eng., 44, 539-544. https://doi.org/10.2208/prohe.44.539

Elawady, E., Michiue, M., \& Hinokidani, O. (2001). Movable bed scour around submerged spur-dikes. Proc. Hydraul. Eng., 45, 373-378. https://doi.org/10.2208/prohe.45.373

Elhakeem, M., Papanicolaou, A. N. T., \& Wilson, C. G. (2017). Implementing streambank erosion control measures in meandering streams: Design procedure enhanced with numerical modelling. Intl. J. River Basin Mgmt., 15(3), 317-327. https://doi.org/10.1080/15715124.2017.1315816

Engelhardt, C., Kruger, A., Sukhodolov, A., \& Nicklisch, A. (2004). A study of phytoplankton spatial distributions, flow structure, and characteristics of mixing in a river reach with groynes. J. Plankton Res., 26(11), 1351-1366. https://doi.org/10.1093/plankt/fbh125

Enlow, H. K., Fox, G. A., Boyer, T. A., Stoecker, A., Storm, D. E., Starks, P., \& Guertault, L. (2018). A modeling framework for evaluating streambank stabilization practices for reach-scale sediment reduction. Environ. Model. Software, 100, 201-212. https://doi.org/10.1016/j.envsoft.2017.11.010

Ettema, R., \& Muste, M. (2004). Scale effects in flume experiments on flow around a spur dike in flatbed channel. J. Hydraul. Eng., 
130(7), 635-646. https://doi.org/10.1061/(ASCE)07339429(2004)130:7(635)

Evette, A., Labonne, S., Rey, F., Liebault, F., Jancke, O., \& Girel, J. (2009). History of bioengineering techniques for erosion control in rivers in western Europe. Environ. Mgmt., 43(6), 972-984. https://doi.org/10.1007/s00267-009-9275-y

Fazli, M., Ghodsian, M., \& Neyshabouri, S. A. A. S. (2008). Scour and flow field around a spur dike in a $90^{\circ}$ bend. Intl. J. Sediment Res., 23(1), 56-68. https://doi.org/10.1016/S10016279(08)60005-0

Flokstra, C. (2006). Modelling of submerged vanes. J. Hydraul. Res., 44(5), 591-602. https://doi.org/10.1080/00221686.2006.9521709

Florsheim, J. L., Mount, J. F., \& Chin, A. (2008). Bank erosion as a desirable attribute of rivers. Bioscience, 58(6), 519-529. https://doi.org/10.1641/b580608

Fox, G. A., Sheshukov, A., Cruse, R., Kolar, R. L., Guertault, L., Gesch, K. R., \& Dutnell, R. C. (2016). Reservoir sedimentation and upstream sediment sources: Perspectives and future research needs on streambank and gully erosion. Environ. Mgmt., 57(5), 945-955. https://doi.org/10.1007/s00267-016-0671-9

Fox, J. F., Papanicolaou, A. N., Hobbs, B., Kramer, C., \& Kjos, L. (2005). Fluid-sediment dynamics around a barb: An experimental case study of a hydraulic structure for the Pacific Northwest. Canadian J. Civil Eng., 32(5), 853-867. https://doi.org/10.1139/105-033

Froehlich, D. C. (2013). Sizing loose rock riprap to protect stream banks. River Res. Appl., 29(2), 219-235. https://doi.org/10.1002/rra.1587

Frothingham, K. M. (2008). Evaluation of stability threshold analysis as a cursory method of screening potential streambank stabilization techniques. Appl. Geogr., 28(2), 124-133. https://doi.org/10.1016/j.apgeog.2007.07.006

Gellis, A. C., \& Gorman Sanisaca, L. (2018). Sediment fingerprinting to delineate sources of sediment in the agricultural and forested Smith Creek watershed, Virginia, USA. JAWRA, 54(6), 1197-1221. https://doi.org/10.1111/1752-1688.12680

Ghodsian, M., \& Vaghefi, M. (2009). Experimental study on scour and flow field in a scour hole around a T-shape spur dike in a $90^{\circ}$ bend. Intl. J. Sediment Res., 24(2), 145-158. https://doi.org/10.1016/S1001-6279(09)60022-6

Gidley, C. A., Scarnecchia, D. L., \& Hansen, J. A. (2012). Fish community structure associated with stabilized and unstabilized shoreline habitats, Coeur d'Alene River, Idaho, USA. River Res. Appl., 28(5), 554-566. https://doi.org/10.1002/rra.1476

Giri, S., Shimizu, Y., \& Fujita, M. (2003). Flow characteristics in a mildly meandering channel with and without river training structures. Proc. Hydraul. Eng., 47, 835-840. https://doi.org/10.2208/prohe.47.835

Giri, S., Shimizu, Y., \& Surajate, B. (2004). Laboratory measurement and numerical simulation of flow and turbulence in a meandering-like flume with spurs. Flow Meas. Instrum., 15(5), 301-309. https://doi.org/10.1016/j.flowmeasinst.2004.05.002

Goudie, A. S. (2006). Global warming and fluvial geomorphology. Geomorphology, 79(3), 384-394. https://doi.org/10.1016/j.geomorph.2006.06.023

Gray, D. H., \& Sotir, R. B. (1996). Biotechnical and soil bioengineering slope stabilization: A practical guide for erosion control. Hoboken, NJ: John Wiley \& Sons.

Gu, Z.-P., Akahori, R., \& Ikeda, S. (2011). Study on the transport of suspended sediment in an open channel flow with permeable spur dikes. Intl. J. Sediment Res., 26(1), 96-111. https://doi.org/10.1016/S1001-6279(11)60079-6
Gupta, U. P., Ojha, C. S. P., \& Sharma, N. (2010). Enhancing utility of submerged vanes with collar. J. Hydraul. Eng., 136(9), 651655. https://doi.org/10.1061/(ASCE)HY.1943-7900.0000212

Hassan, M. A., Roberge, L., Church, M., More, M., Donner, S. D., Leach, J., \& Ali, K. F. (2017). What are the contemporary sources of sediment in the Mississippi River? Geophys. Res. Lett., 44(17), 8919-8924. https://doi.org/10.1002/2017g1074046

Hemmati, M., \& Daraby, P. (2019). Erosion and sedimentation patterns associated with restoration structures of bendway weirs. J. Hydro-Environ. Res., 22, 19-28. https://doi.org/10.1016/j.jher.2018.11.001

Hemmati, M., Ghomeshi, M., Ahmadi, H., \& Lanzoni, S. (2016). Scour depth around flat and sloped crest bendway weirs: A laboratory study. Intl. J. River Basin Mgmt., 14(1), 83-93. https://doi.org/10.1080/15715124.2015.1085870

Holmes, R. J. P., Hayes, J. W., Closs, G. P., Beech, M., Jary, M., \& Matthaei, C. D. (2019). Mechanically reshaping stream banks alters fish community composition. River Res. Appl., 35(3), $247-$ 258. https://doi.org/10.1002/rra.3407

Hoomehr, S., Akinola, A. I., Wynn-Thompson, T., Garnand, W., \& Eick, M. J. (2018). Water temperature, $\mathrm{pH}$, and road salt impacts on the fluvial erosion of cohesive streambanks. Water, 10(3), 302. https://doi.org/10.3390/w10030302

Iowa DNR. (2006). How to control streambank erosion. Des Moines, IA: Iowa Department of Natural Resources, Retrieved from

www.iowadnr.gov/portals/idnr/uploads/water/stormwater/stream bankmanual.pdf

Jafarnejad, M., Franca, M. J., Pfister, M., \& Schleiss, A. J. (2019). Design of riverbank riprap using large, individually placed blocks. J. Hydraul. Eng., 145(12), 04019042. https://doi.org/10.1061/(ASCE)HY.1943-7900.0001641

Jafarnejad, M., Pfister, M., Bruhwiler, E., \& Schleiss, A. J. (2017). Probabilistic failure analysis of riprap as riverbank protection under flood uncertainties. Stochastic Environ. Res. Risk Assess., 31(7), 1839-1851. https://doi.org/10.1007/s00477-016-1368-6

Jamieson, E. C., Rennie, C. D., \& Townsend, R. D. (2013a). 3D flow and sediment dynamics in a laboratory channel bend with and without stream barbs. J. Hydraul. Eng., 139(2), 154-166. https://doi.org/10.1061/(ASCE)HY.1943-7900.0000655

Jamieson, E. C., Rennie, C. D., \& Townsend, R. D. (2013b). Turbulence and vorticity in a laboratory channel bend at equilibrium clear-water scour with and without stream barbs. $J$. Hydraul. Eng., 139(3), 259-268. https://doi.org/10.1061/(ASCE)HY.1943-7900.0000673

Jia, Y., Scott, S., Xu, Y., \& Wang, S. S. Y. (2009). Numerical study of flow affected by bendway weirs in Victoria Bendway, the Mississippi River. J. Hydraul. Eng., 135(11), 902-916. https://doi.org/10.1061/(ASCE)0733-9429(2009)135:11(902)

Jia, Y., Scott, S., Xu, Y., Huang, S., \& Wang, S. Y. (2005). Threedimensional numerical simulation and analysis of flows around a submerged weir in a channel bendway. J. Hydraul. Eng., 131(8), 682-693. https://doi.org/10.1061/(ASCE)07339429(2005)131:8(682)

Johnson, P. A., Hey, R. D., Brown, E. R., \& Rosgen, D. L. (2002). Stream restoration in the vicinity of bridges. JAWRA, 38(1), 5567. https://doi.org/10.1111/j.1752-1688.2002.tb01534.x

Johnson, P. A., Hey, R. D., Tessier, M., \& Rosgen, D. L. (2001). Use of vanes for control of scour at vertical wall abutments. $J$. Hydraul. Eng., 127(9), 772-778. https://doi.org/10.1061/(ASCE)0733-9429(2001)127:9(772)

Jorgensen, J. C., Mcclure, M. M., Sheer, M. B., \& Munn, N. L. (2013). Combined effects of climate change and bank stabilization on shallow water habitats of Chinook salmon. Conserv. Biol., 27(6), 1201-1211. https://doi.org/10.1111/cobi.12168 
Juracek, K. E., \& Ziegler, A. C. (2009). Estimation of sediment sources using selected chemical tracers in the Perry Lake basin, Kansas, USA. Intl. J. Sediment Res., 24(1), 108-125. https://doi.org/10.1016/S1001-6279(09)60020-2

Karki, S., Nakagawa, H., Kawaike, K., \& Hashimoto, M. (2018). Experimental study on the performance of slope-crested groynes in erodible meandering channels of different sinuosity. J. Japan Soc. Nat. Disaster Sci. (JSNDS), 37, 93-105.

Khosronejad, A., Diplas, P., \& Sotiropoulos, F. (2017). Simulationbased optimization of in-stream structures design: Bendway weirs. Environ. Fluid Mech., 17(1), 79-109.

https://doi.org/10.1007/s10652-016-9452-5

Khosronejad, A., Hill, C., Kang, S., \& Sotiropoulos, F. (2013). Computational and experimental investigation of scour past laboratory models of stream restoration rock structures. $A d v$. Water Resour., 54, 191-207. https://doi.org/10.1016/j.advwatres.2013.01.008

Khosronejad, A., Kozarek, J. L., \& Sotiropoulos, F. (2014b). Simulation-based approach for stream restoration structure design: Model development and validation. J. Hydraul. Eng., 140(9), 1-16. https://doi.org/10.1061/(ASCE)HY.19437900.0000904

Khosronejad, A., Kozarek, J. L., Palmsten, M. L., \& Sotiropoulos, F. (2014a). Numerical simulation of large dunes in meandering streams and rivers with in-stream rock structures. Adv. Water Resour., 81, 45-61. https://doi.org/10.1016/j.advwatres.2014.09.007

Kinzli, K.-D., \& Thornton, C. I. (2010). Predicting velocity in bendway weir eddy fields. River Res. Appl., 26(7), 823-834. https://doi.org/10.1002/rra.1289

Koken, M. (2011). Coherent structures around isolated spur dikes at various approach flow angles. J. Hydraul. Eng., 49(6), 736-743. https://doi.org/10.1080/00221686.2011.616316

Koken, M., \& Constantinescu, G. (2008a). An investigation of the flow and scour mechanisms around isolated spur dikes in a shallow open channel: 1 . Conditions corresponding to the initiation of the erosion and deposition process. Water Resour. Res., 44(8), 1-19. https://doi.org/10.1029/2007wr006489

Koken, M., \& Constantinescu, G. (2008b). An investigation of the flow and scour mechanisms around isolated spur dikes in a shallow open channel: 2. Conditions corresponding to the final stages of the erosion and deposition process. Water Resour. Res., 44(8), 1-16. https://doi.org/10.1029/2007wr006491

Koken, M., \& Gogus, M. (2015). Effect of spur dike length on the horseshoe vortex system and the bed shear stress distribution. $J$. Hydraul. Res., 53(2), 196-206. https://doi.org/10.1080/00221686.2014.967819

Kondolf, G. M. (1997). Hungry water: Effects of dams and gravel mining on river channels. Environ. Mgmt., 21(4), 533-551. https://doi.org/10.1007/s002679900048

Kothyari, U. C., \& Ranga Raju, K. G. (2001). Scour around spur dikes and bridge abutments. J. Hydraul. Res., 39(4), 367-374. https://doi.org/10.1080/00221680109499841

Krymer, V., \& Robert, A. (2014). Stream restoration and cribwall performance: A case study of cribwall monitoring in southern Ontario. River Res. Appl., 30(7), 865-873. https://doi.org/10.1002/rra.2684

Kuhnle, R. A., Alonso, C. V., \& Shields Jr., F. D. (1999). Geometry of scour holes associated with $90^{\circ}$ spur dikes. J. Hydraul. Eng., 125(9), 972-978. https://doi.org/10.1061/(ASCE)07339429(1999)125:9(972)

Kuhnle, R. A., Alonso, C. V., \& Shields Jr., F. D. (2002). Local scour associated with angled spur dikes. J. Hydraul. Eng., 128(12), 1087-1093. https://doi.org/10.1061/(ASCE)07339429(2002)128:12(1087)
Kuhnle, R. A., Jia, Y., \& Alonso, C. V. (2008). Measured and simulated flow near a submerged spur dike. J. Hydraul. Eng., 134(7), 916-924. https://doi.org/10.1061/(ASCE)07339429(2008)134:7(916)

Kuhnle, R., \& Alonso, C. (2013). Flow near a model spur dike with a fixed scoured bed. Intl. J. Sediment Res., 28(3), 349-357. https://doi.org/10.1016/S1001-6279(13)60045-1

Lagasse, P. F., Clopper, P. E., Pagan-Ortiz, J. E., Zevenbergen, L. W., Arneson, L. A., Schall, J. D., \& Girard, L. G. (2009). Bridge scour and stream instability countermeasures: Experience, selection, and design guidance. Hydraulic Engineering Circular No. 23. Arlington, VA: U.S. Department of Transportation.

Lammers, R. W., Bledsoe, B. P., \& Langendoen, E. J. (2016). Uncertainty and sensitivity in a bank stability model: Implications for estimating phosphorus loading. Earth Surf. Proc. Landforms, 42(4), 612-623. https://doi.org/10.1002/esp.4004

Langendoen, E. J., \& Simon, A. (2008). Modeling the evolution of incised streams: II. Streambank erosion. J. Hydraul. Eng., 134(7), 905-915. https://doi.org/10.1061/(ASCE)07339429(2008)134:7(905)

Larsen, E. W., \& Greco, S. E. (2002). Modeling channel management impacts on river migration: A case study of Woodson Bridge State Recreation Area, Sacramento River, California, USA. Environ. Mgmt., 30(2), 209-224. https://doi.org/10.1007/s00267-002-2663-1

Li, M. H., \& Eddleman, K. E. (2002). Biotechnical engineering as an alternative to traditional engineering methods: A biotechnical streambank stabilization design approach. Landscape Urban Plan., 60(4), 225-242. https://doi.org/10.1016/S01692046(02)00057-9

Li, K., Zhang, Z., Yang, H., Bian, H., Jiang, H., Sheng, L., \& He, C. (2018). Effects of instream restoration measures on the physical habitats and benthic macroinvertebrates in an agricultural headwater stream. Ecol. Eng., 122, 252-262. https://doi.org/10.1016/j.ecoleng.2018.08.007

Li, X., Zhang, L., \& Zhang, Z. (2006). Soil bioengineering and the ecological restoration of riverbanks at the Airport Town, Shanghai, China. Ecol. Eng., 26(3), 304-314. https://doi.org/10.1016/j.ecoleng.2005.10.011

Marelius, F., \& Sinha, S. K. (1998). Experimental investigation of flow past submerged vanes. J. Hydraul. Eng., 124(5), 542-545. https://doi.org/10.1061/(ASCE)0733-9429(1998)124:5(542)

Massey, W., Biron, P. M., \& Chone, G. (2017). Impacts of river bank stabilization using riprap on fish habitat in two contrasting environments. Earth Surf. Proc. Landforms, 42(4), 635-646. https://doi.org/10.1002/esp.4010

Matsuura, T., \& Townsend, R. (2004). Stream-barb installations for narrow channel bends: A laboratory study. Canadian J. Civil Eng., 31(3), 478-486. https://doi.org/10.1139/104-017

McCoy, A., Constantinescu, G., \& Weber, L. (2007). A numerical investigation of coherent structures and mass exchange processes in channel flow with two lateral submerged groynes. Water Resour. Res., 43(5), 1-26. https://doi.org/10.1029/2006wr005267

McCoy, A., Constantinescu, G., \& Weber, L. J. (2008). Numerical investigation of flow hydrodynamics in a channel with a series of groynes. J. Hydraul. Eng., 134(2), 157-172. https://doi.org/10.1061/(ASCE)0733-9429(2008)134:2(157)

Melville, B. W. (1992). Local scour at bridge abutments. $J$. Hydraul. Eng., 118(4), 615-631. https://doi.org/10.1061/(ASCE)0733-9429(1992)118:4(615)

Miller, J. R., \& Craig Kochel, R. (2010). Assessment of channel dynamics, in-stream structures, and post-project channel adjustments in North Carolina and its implications to effective 
stream restoration. Environ. Earth Sci., 59(8), 1681-1692. https://doi.org/10.1007/s12665-009-0150-1

Miller, J. R., \& Craig Kochel, R. (2013). Use and performance of in-stream structures for river restoration: A case study from North Carolina. Environ. Earth Sci., 68(6), 1563-1574. https://doi.org/10.1007/s12665-012-1850-5

Minor, B., Rennie, C. D., \& Townsend, R. D. (2007). "Barbs" for river bend bank protection: Application of a three-dimensional numerical model. Canadian J. Civil Eng., 34(9), 1087-1095. https://doi.org/10.1139/107-088

Moerke, A. H., \& Lamberti, G. A. (2004). Restoring stream ecosystems: Lessons from a midwestern state. Restor. Ecol., 12(3), 327-334. https://doi.org/10.1111/j.10612971.2004.0340.x

Morris, L. L., McVey, M. J., Lohnes, R. A., \& Baumel, C. P. (1996). Estimates of future impacts of degrading streams in the deep loess soil region of western Iowa on private and public infrastructure costs. Eng. Geol., 43(4), 255-264. https://doi.org/10.1016/S0013-7952(96)00035-X

Nagata, N., Hosoda, T., Nakato, T., \& Muramoto, Y. (2005). Threedimensional numerical model for flow and bed deformation around river hydraulic structures. J. Hydraul. Eng., 131(12), 1074-1087. https://doi.org/10.1061/(ASCE)07339429(2005)131:12(1074)

Nasrollahi, A., Ghodsian, M., \& Neyshabouri, S. A. A. S. (2006) Local scour at permeable spur dikes. J. Appl. Sci., 8(19), 33983406.

Niezgoda, S. L., \& Johnson, P. A. (2006). Modeling the long-term impacts of using rigid structures in stream channel restoration. JAWRA, 42(6), 1597-1613. https://doi.org/10.1111/j.17521688.2006.tb06023.x

NRCS. (1996). Chapter 16: Streambank and shoreline protection. In Engineering field handbook: Part 650 (pp. 16-1 to 16-88). Washington, DC: USDA Natural Resources Conservation Service.

NRCS. (2005). Design of stream barbs. Tech. Note No. 23. Washington, DC: USDA Natural Resources Conservation Service.

Odgaard, A. J., \& Kennedy, J. F. (1983). River-bend bank protection by submerged vanes. J. Hydraul. Eng., 109(8), 11611173. https://doi.org/10.1061/(ASCE)07339429(1983)109:8(1161)

Ouyang, H., \& Lu, C. (2016). Optimizing the spacing of submerged vanes across rivers for streambank protection at channel bends. J. Hydraul. Eng., 142(12), 1-12. https://doi.org/10.1061/(ASCE)HY.1943-7900.0001210

Ouyang, H.-T. (2009). Investigation on the dimensions and shape of a submerged vane for sediment management in alluvial channels. J. Hydraul. Eng., 135(3), 209-217. https://doi.org/10.1061/(ASCE)0733-9429(2009)135:3(209)

Ouyang, H.-T., \& Lin, C.-P. (2016). Characteristics of interactions among a row of submerged vanes in various shapes. J. HydroEnviron. Res., 13, 14-25. https://doi.org/10.1016/j.jher.2016.05.003

Ouyang, H.-T., Lai, J.-S., Yu, H., \& Lu, C.-H. (2008). Interaction between submerged vanes for sediment management. $J$. Hydraul. Eng., 46(5), 620-627. https://doi.org/10.3826/jhr.2008.3160

Pagliara, S., \& Kurdistani, S. M. (2017). Flume experiments on scour downstream of wood stream restoration structures. Geomorphology, 279, 141-149. https://doi.org/10.1016/j.geomorph.2016.10.013

Pagliara, S., \& Kurdistani, S. M. (2015). Clear water scour at Jhook vanes in channel bends for stream restorations. Ecol. Eng., 83, 386-393. https://doi.org/10.1016/j.ecoleng.2015.07.003
Pagliara, S., Hassanabadi, L. S., \& Kurdistani, S. M. (2015a). Clear water scour downstream of log deflectors in horizontal channels. J. Irrig. Drain. Eng., 141(9), 04015007. https://doi.org/10.1061/(ASCE)IR.1943-4774.0000869

Pagliara, S., Kurdistani, S. M., \& Santucci, I. (2013). Scour downstream of J-Hook vanes in straight horizontal channels. Acta Geophys., 61(5), 1211-1228. https://doi.org/10.2478/s11600-013-0143-Z

Pagliara, S., Hassanabadi, L. S., \& Kurdistani, S. M. (2015b). Logvane scour in clear water condition. River Res. Appl., 31(9), 1176-1182. https://doi.org/10.1002/rra.2799

Palmer, M. A., Bernhardt, E. S., Allan, J. D., Lake, P. S., Alexander, G., Brooks, S., ... Sudduth, E. (2005). Standards for ecologically successful river restoration. J. Appl. Ecol., 42(2), 208-217. https://doi.org/10.1111/j.1365-2664.2005.01004.x

Pandey, M., Ahmad, Z., \& Sharma, P. K. (2016). Estimation of maximum scour depth near a spur dike. Canadian J. Civil Eng., 43(3), 270-278. https://doi.org/10.1139/cjce-2015-0280

Papanicolaou, A. N., Elhakeem, M., \& Hilldale, R. (2007). Secondary current effects on cohesive river bank erosion. Water Resour. Res., 43(W12418). https://doi.org/10.1029/2006wr005763

Papanicolaou, A. N., Elhakeem, M., \& Wardman, B. (2011a). Calibration and verification of a 2D hydrodynamic model for simulating flow around emergent bendway weir structures. $J$. Hydraul. Eng., 137(1), 75-89. https://doi.org/10.1061/(ASCE)HY.1943-7900.0000280

Papanicolaou, A. N., Elhakeem, M., Dermisis, D., \& Young, N. (2011b). Evaluation of the Missouri River shallow water habitat using a 2D-hydrodynamic model. River Res. Appl., 27(2), 157167. https://doi.org/10.1002/rra.1344

Parker, C., Simon, A., \& Thorne, C. R. (2008). The effects of variability in bank material properties on riverbank stability: Goodwin Creek, Mississippi. Geomorphology, 101(4), 533-543. https://doi.org/10.1016/j.geomorph.2008.02.007

Petrone, A., \& Preti, F. (2008). Suitability of soil bioengineering techniques in Central America: A case study in Nicaragua. Hydrol. Earth Syst. Sci., 12(5), 1241-1248. https://doi.org/10.5194/hess-12-1241-2008

Pezeshki, S. R., Li, S., Shields Jr., F. D., \& Martin, L. T. (2007). Factors governing survival of black willow (Salix nigra) cuttings in a streambank restoration project. Ecol. Eng., 29(1), 56-65. https://doi.org/10.1016/j.ecoleng.2006.07.014

Pollen, N. (2007). Temporal and spatial variability in root reinforcement of streambanks: Accounting for soil shear strength and moisture. Catena, 69(3), 197-205. https://doi.org/10.1016/j.catena.2006.05.004

Pretty, J. L., Harrison, S. S. C., Shepherd, D. J., Smith, C., Hildrew, A. G., \& Hey, R. D. (2003). River rehabilitation and fish populations: Assessing the benefit of instream structures. $J$. Appl. Ecol., 40(2), 251-265. https://doi.org/10.1046/j.13652664.2003.00808.x

Radspinner, R. R., Diplas, P., Lightbody, A. F., \& Sotiropoulos, F. (2010). River training and ecological enhancement potential using in-stream structures. J. Hydraul. Eng., 136(12), 967-980. https://doi.org/10.1061/(ASCE)HY.1943-7900.0000260

Rahman, M. M., \& Haque, M. A. (2004). Local scour at sloped-wall spur-dike-like structures in alluvial rivers. J. Hydraul. Eng., 130(1), 70-74. https://doi.org/10.1061/(ASCE)07339429(2004)130:1(70)

Rahman, M. M., Nakagawa, H., Ito, N., Haque, A., Islam, T., Rahman, M. R., \& Hoque, M. M. (2006). Prediction of local scour depth around bandal-like structures. Proc. Hydraul. Eng., 50, 163-168. https://doi.org/10.2208/prohe.50.163 
Rahman, M. M., \& Muramoto, Y. (1999). Prediction of maximum scour depth around spur-dike-like structures. Proc. Hydraul. Eng., 43, 623-628. https://doi.org/10.2208/prohe.43.623

Recking, A., Piton, G., Montabonnet, L., Posi, S., \& Evette, A. (2019). Design of fascines for riverbank protection in alpine rivers: Insight from flume experiments. Ecol. Eng., 138, 323333. https://doi.org/10.1016/j.ecoleng.2019.07.019

Reid, D., \& Church, M. (2015). Geomorphic and ecological consequences of riprap placement in river systems. JAWRA, 51(4), 1043-1059. https://doi.org/10.1111/jawr.12279

Roca, M., Blanckaert, K., \& Martin-Vide, J. P. (2009). Reduction of bend scour by an outer bank footing: Flow field and turbulence. J. Hydraul. Eng., 135(5), 361-368. https://doi.org/10.1061/(ASCE)HY.1943-7900.0000028

Roca, M., Martin-Vide, J. P., \& Blanckaert, K. (2007). Reduction of bend scour by an outer bank footing: Footing design and bed topography. J. Hydraul. Eng., 133(2), 139-147.

https://doi.org/10.1061/(ASCE)0733-9429(2007)133:2(139)

Rosgen, D. L. (1996). Applied river morphology (2nd Ed.). Pagosa Springs, CO: Wildland Hydrology.

Rosgen, D. L. (2008). Discussion "Critical evaluation of how the Rosgen classification and associated 'natural channel design' methods fail to integrate and quantify fluvial processes and channel responses". JAWRA, 44(3), 782-792. https://doi.org/10.1111/j.1752-1688.2008.00169.x

Schiff, R., Benoit, G., \& MacBroom, J. (2011). Evaluating stream restoration: A case study from two partially developed 4th order Connecticut, USA streams and evaluation monitoring strategies. River Res. Appl., 27(4), 431-460. https://doi.org/10.1002/rra.1365

Schwartz, R., \& Kozerski, H.-P. (2003). Entry and deposits of suspended particulate matter in groyne fields of the Middle Elbe and its ecological relevance. Acta Hydrochim. Hydrobiol., 31(45), 391-399. https://doi.org/10.1002/aheh.200300496

Scurlock, S. M., Thornton, C. I., Baird, D. C., \& Abt, S. R. (2015). Quantification of transverse in-stream structure hydraulics. $J$. Hydraul. Eng., 141(2), 1-9. https://doi.org/10.1061/(ASCE)HY.1943-7900.0000952

Sharma, H., Jain, B., \& Ahmad, Z. (2016). Optimization of submerged vane parameters. Sadhana, 41(3), 327-336. https://doi.org/10.1007/s12046-016-0477-8

Shields Jr., F. D., Copeland, R. R., Klingeman, P. C., Doyle, M. W., \& Simon, A. (2003a). Design for stream restoration. J. Hydraul. Eng., 129(8), 575-584. https://doi.org/10.1061/(ASCE)07339429(2003)129:8(575)

Shields Jr., F. D., Knight, S. S., \& Cooper, C. M. (1998a). Addition of spurs to stone toe protection for warmwater fish habitat rehabilitation. JAWRA, 34(6), 1427-1436. https://doi.org/10.1111/j.1752-1688.1998.tb05442.x

Shields Jr., F. D., Knight, S. S., \& Cooper, C. M. (1998b). Rehabilitation of aquatic habitats in warmwater streams damaged by channel incision in Mississippi. Hydrobiologia, 382(1), 63-86. https://doi.org/10.1023/A:1003485021076

Shields Jr., F. D., Knight, S. S., \& Cooper, C. M. (2000). Warmwater stream bank protection and fish habitat: A comparative study. Environ. Mgmt., 26(3), 317-328. https://doi.org/10.1007/s002670010089

Shields Jr., F. D., Knight, S. S., \& Stofleth, J. M. (2006). Large wood addition for aquatic habitat rehabilitation in an incised, sand-bed stream, Little Topashaw Creek, Mississippi. River Res. Appl., 22(7), 803-817. https://doi.org/10.1002/rra.937

Shields Jr., F. D., Knight, S. S., Morin, N., \& Blank, J. (2003b). Response of fishes and aquatic habitats to sand-bed stream restoration using large woody debris. Hydrobiologia, 494(1-3), 251-257. https://doi.org/10.1007/978-94-017-3366-3_34
Shields Jr., F. D., Morin, N., \& Cooper, C. M. (2004). Large woody debris structures for sand-bed channels. J. Hydraul. Eng., 130(3), 208-217. https://doi.org/10.1061/(ASCE)07339429(2004)130:3(208)

Shields Jr., F. D., Pezeshki, S. R., Wilson, G. V., Wu, W., \& Dabney, S. M. (2008). Rehabilitation of an incised stream using plant materials: The dominance of geomorphic processes. Ecol. Soc., 13(2), 54. https://doi.org/10.5751/ES-02651-130254

Shih, S.-S., Lee, H.-Y., \& Chen, C.-C. (2008). Model-based evaluations of spur dikes for fish habitat improvement: A case study of endemic species Varicorhinus barbatulus (Cyprinidae) and Hemimyzon formosanum (Homalopteridae) in Lanyang River, Taiwan. Ecol. Eng., 34(2), 127-136. https://doi.org/10.1016/j.ecoleng.2008.07.016

Simon, A., \& Hupp, C. R. (1986). Channel evolution in modified Tennessee channels. Proc. 4th Federal Interagency Sedimentation Conf. (vol. 2, pp. 5.71-5.82). Reston, VA: U.S. Geological Survey.

Simon, A., \& Rinaldi, M. (2000). Channel instability in the loess area of the midwestern United States. JAWRA, 36(1), 133-150. https://doi.org/10.1111/j.1752-1688.2000.tb04255.x

Simon, A., Curini, A., Darby, S. E., \& Langendoen, E. J. (2000). Bank and near-bank processes in an incised channel. Geomorphology, 35(3), 193-217. https://doi.org/10.1016/S0169$555 \mathrm{X}(00) 00036-2$

Simon, A., Doyle, M., Kondolf, M., Shields Jr., F. D., Rhoads, B., \& McPhillips, M. (2007). Critical evaluation of how the Rosgen classification and associated "natural channel design" methods fail to integrate and quantify fluvial processes and channel response. JAWRA, 43(5), 1117-1131. https://doi.org/10.1111/j.1752-1688.2007.00091.x

Simon, A., Pollen-Bankhead, N., Mahacek, V., \& Langendoen, E. (2009). Quantifying reductions of mass-failure frequency and sediment loadings from streambanks using toe protection and other means: Lake Tahoe, United States. JAWRA, 45(1), 170186. https://doi.org/10.1111/j.1752-1688.2008.00268.x

Simon, K., \& Steinemann, A. (2000). Soil bioengineering: Challenges for planning and engineering. J. Urban Plan. Devel., 126(2), 89-102. https://doi.org/10.1061/(ASCE)07339488(2000)126:2(89)

Sinha, S. K., \& Marelius, F. (2000). Analysis of flow past submerged vanes. J. Hydraul. Res., 38(1), 65-71. https://doi.org/10.1080/00221680009498360

Sudduth, E. B., \& Meyer, J. L. (2006). Effects of bioengineered streambank stabilization on bank habitat and macroinvertebrates in urban streams. Environ. Mgmt., 38(2), 218-226. https://doi.org/10.1007/s00267-004-0381-6

Sukhodolov, A., Engelhardt, C., Kruger, A., \& Bungartz, H. (2004). Case study: Turbulent flow and sediment distributions in a groyne field. J. Hydraul. Eng., 130(1), 1-9. https://doi.org/10.1061/(ASCE)0733-9429(2004)130:1(1)

Sukhodolov, A., Uijttewaal, W. S. J., \& Engelhardt, C. (2002). On the correspondence between morphological and hydrodynamical patterns of groyne fields. Earth Surf. Proc. Landforms, 27(3), 289-305. https://doi.org/10.1002/esp.319

Tan, S.-K., Yu, G., Lim, S.-Y., \& Ong, M.-C. (2005). Flow structure and sediment motion around submerged vanes in open channel. J. Waterway Port Coastal Ocean Eng., 131(3), 132136. https://doi.org/10.1061/(ASCE)0733950X(2005)131:3(132)

Ten Brinke, W. B. M., Schulze, F. H., \& van Der Veer, P. (2004). Sand exchange between groyne-field beaches and the navigation channel of the Dutch Rhine: The impact of navigation versus river flow. River Res. Appl., 20(8), 899-928. https://doi.org/10.1002/rra.809 
Teraguchi, H., Nakagawa, H., Kawaike, K., Baba, Y., \& Zhang, H. (2011). Effects of hydraulic structures on river morphological processes. Intl. J. Sediment Res., 26(3), 283-303. https://doi.org/10.1016/S1001-6279(11)60094-2

Testa III, S., Shields Jr., F. D., \& Cooper, C. M. (2010). Macroinvertebrate response to stream restoration by large wood addition. Ecohydrology, 4(5), 631-643. https://doi.org/10.1002/eco.146

Thompson, D. M. (2002). Long-term effect of instream habitatimprovement structures on channel morphology along the Blackledge and Salmon Rivers, Connecticut, USA. Environ. Mgmt., 29(1), 250-265. https://doi.org/10.1007/s00267-0010069-0

Thompson, D. M., \& Stull, G. N. (2002). The development and historic use of habitat structures in channel restoration in the United States: The grand experiment in fisheries management. Geographie Physique et Quaternaire, 56(1), 45-60. https://doi.org/10.7202/008604ar

Thompson, D. M., Puklin, L. S., \& Marshall, A. E. (2016). The long-term impact of channel stabilization using gabion structures on Zealand River, New Hampshire. Ecol. Eng., 95, 779-792. https://doi.org/10.1016/j.ecoleng.2016.07.016

Thorne, C. R. (1999). Bank processes and channel evolution in the incised rivers of north-central Mississippi. In S. E. Darby \& A. Simon (Eds.), Incised river channels: Processes, forms, engineering, and management (pp. 97-121). Hoboken, NJ: John Wiley \& Sons.

Trimble, S. W. (1997). Contribution of stream channel erosion to sediment yield from an urbanizing watershed. Science, 278(5342), 1442-1444. https://doi.org/10.1126/science.278.5342.1442

Tritthart, M., Liedermann, M., \& Habersack, H. (2009). Modelling spatio-temporal flow characteristics in groyne fields. River Res. Appl., 25, 62-81. https://doi.org/10.1002/rra.1169

Uijttewaal, W. S. J. (2005). Effects of groyne layout on the flow in groyne fields: Laboratory experiments. J. Hydraul. Eng., 131(9), 782-791. https://doi.org/10.1061/(ASCE)07339429(2005)131:9(782)

Uijttewaal, W. S. J., Lehmann, D., \& van Mazijk, A. (2001). Exchange processes between a river and its groyne fields: Model experiments. J. Hydraul. Eng., 127(11), 928-936. https://doi.org/10.1061/(ASCE)0733-9429(2001)127:11(928)

Veller, J. C., \& Doyle, P. F. (2001). Field performance of conventional tree revetment bank protection. Canadian Water Resour. J., 26(1), 91-105. https://doi.org/10.4296/cwrj2601091

Voisin, A., \& Townsend, R. D. (2002). Model testing of submerged vanes in strongly curved narrow channel bends. Canadian $J$. Civil Eng., 29(1), 37-49. https://doi.org/10.1139/101-078

Vörösmarty, C. J., McIntyre, P. B., Gessner, M. O., Dudgeon, D., Prusevich, A., Green, P., ... Davies, P. M. (2010). Global threats to human water security and river biodiversity. Nature, 467(7315), 555-561. https://doi.org/10.1038/nature09440

Walling, D. E., \& Fang, D. (2003). Recent trends in the suspended sediment loads of the world's rivers. Global Planetary Change, 39(1), 111-126. https://doi.org/10.1016/S0921-8181(03)00020-1

Watson, C. C., Abt, S. R., \& Derrick, D. (1997). Willow posts bank stabilization. JAWRA, 33(2), 293-300. https://doi.org/10.1111/j.1752-1688.1997.tb03510.x

White, K., Gerken, J., Paukert, C., \& Makinster, A. (2010). Fish community structure in natural and engineered habitats in the Kansas River. River Res. Appl., 26(7), 797-805. https://doi.org/10.1002/rra.1287

Wohl, E., Angermeier, P. L., Bledsoe, B., Kondolf, G. M., MacDonnell, L., Merritt, D. M., ... Tarboton, D. (2005). River restoration. Water Resour. Res., 41(10). https://doi.org/10.1029/2005wr003985

Wu, B., Wang, G., Ma, J., \& Zhang, R. (2005). Case study: River training and its effects on fluvial processes in the Lower Yellow River, China. J. Hydraul. Eng., 131(2), 85-96. https://doi.org/10.1061/(ASCE)0733-9429(2005)131:2(85)

Yossef, M. F. M., \& de Vriend, H. J. (2010). Sediment exchange between a river and its groyne fields: Mobile-bed experiment. $J$. Hydraul. Eng., 136(9), 610-625. https://doi.org/10.1061/(ASCE)HY.1943-7900.0000226

Zhang, H., \& Nakagawa, H. (2009). Characteristics of local flow and bed deformation at impermeable and permeable spur dykes. Ann. J. Hydraul. Eng., 53, 145-150.

Zhang, H., Nakagawa, H., \& Mizutani, H. (2012). Bed morphology and grain size characteristics around a spur dyke. Intl. J. Sediment Res., 27(2), 141-157. https://doi.org/10.1016/S10016279(12)60023-7

Zhang, H., Nakagawa, H., Kawaike, K., \& Baba, Y. (2009). Experiment and simulation of turbulent flow in local scour around a spur dyke. Intl. J. Sediment Res., 24(1), 33-45. https://doi.org/10.1016/S1001-6279(09)60014-7

Zhang, Z., Cao, L., Zhu, Z., He, C., Xiang, H., Xu, L., ... Li, K. (2019). Evaluation on soil bioengineering measures in agricultural areas: Poorer durability of wooden structures and better aboveground habitat improvements. Ecol. Eng., 129, 1-10. https://doi.org/10.1016/j.ecoleng.2019.01.004

Zhou, T., \& Endreny, T. (2012). Meander hydrodynamics initiated by river restoration deflectors. Hydrol. Proc., 26(22), 33783392. https://doi.org/10.1002/hyp.8352

\section{APPENDIX}

See following pages. 


\section{APPENDIX}

Table A1. Summary of impermeable spur physical models (1998-2019) $(\mathrm{N} / \mathrm{A}=$ not applicable; $\mathrm{N} / \mathrm{R}=$ not reported).

\begin{tabular}{|c|c|c|c|c|c|c|c|c|c|c|c|c|c|}
\hline \multirow[b]{2}{*}{ Study } & \multirow[b]{2}{*}{ Objective } & \multirow{2}{*}{$\begin{array}{c}\text { Spatial } \\
\text { Scale }\end{array}$} & \multirow{2}{*}{$\begin{array}{c}\text { Time } \\
\text { Scale }^{[a]}\end{array}$} & \multicolumn{4}{|c|}{ Channel Conditions } & \multicolumn{5}{|c|}{ Structure Properties ${ }^{[\mathrm{d}]}$} & \multirow[b]{2}{*}{ Results } \\
\hline & & & & Planform & $\mathrm{W} / \mathrm{D}^{[\mathrm{b}]}$ & Slope $\mathrm{e}^{[\mathrm{c}]}$ & Boundaries & Angle & $\mathrm{H}$ & $\mathrm{L}$ & Spacing & Plan $^{[\mathrm{e}]}$ & \\
\hline $\begin{array}{l}\text { Pandey et al. } \\
\quad(2016)\end{array}$ & Bedload & Site & $\begin{array}{c}\text { Variable } \\
\text { flow }\end{array}$ & Straight & $\begin{array}{l}\text { Narrow to } \\
\text { moderate }\end{array}$ & Low & $\begin{array}{l}\text { Fixed bank, } \\
\text { uniform } \\
\text { mobile bed }\end{array}$ & $90^{\circ}$ & $\begin{array}{c}\text { Bank } \\
\text { height }\end{array}$ & $\begin{array}{l}0.06 \text { to } \\
0.2 \times \mathrm{W}\end{array}$ & N/A & Single & $\begin{array}{l}\text { Developed an equation to predict } \\
\text { maximum scour depth and length } \\
\text { around spur. }\end{array}$ \\
\hline $\begin{array}{l}\text { Scurlocket al. } \\
\quad(2015)\end{array}$ & Flow & Site & $\begin{array}{c}\text { Variable } \\
\text { flow }\end{array}$ & Meander & $\mathrm{N} / \mathrm{R}$ & Low & $\begin{array}{c}\text { Fixed bank } \\
\text { and bed }\end{array}$ & $\begin{array}{l}60^{\circ} \\
\text { to } 90^{\circ}\end{array}$ & $\begin{array}{l}\text { Up to } \\
\text { bank } \\
\text { height }\end{array}$ & $\begin{array}{c}0.12 \text { to } \\
0.34 \times W\end{array}$ & $\begin{array}{c}0.6 \text { to } \\
3.1 \times W\end{array}$ & Multiple & $\begin{array}{l}\text { Developed "rapid" method to esti- } \\
\text { mate hydraulic effects of impermea- } \\
\text { ble spurs, bendway weirs, and rock } \\
\text { vanes. }\end{array}$ \\
\hline $\begin{array}{l}\text { Deghani et al. } \\
\text { (2013) }\end{array}$ & Bedload & Site & $\begin{array}{c}\text { Variable } \\
\text { flow }\end{array}$ & Straight & Narrow & Low & $\begin{array}{l}\text { Fixed bank, } \\
\text { uniform } \\
\text { mobile bed }\end{array}$ & $90^{\circ}$ & $\begin{array}{c}\text { Bank } \\
\text { height }\end{array}$ & $0.13 \times W$ & N/A & Single & $\begin{array}{l}\text { Upstream-facing L-shaped spurs re- } \\
\text { sulted in least scour compared to } \\
\text { downstream-facing regular spurs. }\end{array}$ \\
\hline $\begin{array}{l}\text { Burele et al. } \\
\quad(2012\end{array}$ & $\begin{array}{l}\text { Bank } \\
\text { erosion, } \\
\text { flow, and } \\
\text { bedload }\end{array}$ & Site & $\begin{array}{c}\text { Variable } \\
\text { flow }\end{array}$ & Meander & Wide & Low & $\begin{array}{l}\text { Fixed bank, } \\
\text { nonuniform } \\
\text { mobile bed }\end{array}$ & $90^{\circ}$ & $\begin{array}{c}\text { Bank } \\
\text { height }\end{array}$ & $\begin{array}{c}0.01 \text { to } \\
0.03 \times \mathrm{W}\end{array}$ & $0.01 \times \mathrm{L}$ & Multiple & $\begin{array}{l}\text { Used a physical model to design two } \\
\text { spurs that deflected flow, reduced } \\
\text { velocity, and induced deposition } \\
\text { along bank. }\end{array}$ \\
\hline $\begin{array}{l}\text { Zhang et al. } \\
\text { (2012) }\end{array}$ & Bedload & Site & $\begin{array}{c}\text { Single } \\
\text { event }\end{array}$ & Straight & Narrow & Low & $\begin{array}{c}\text { Fixed bank, } \\
\text { nonuniform } \\
\text { mobile bed }\end{array}$ & $90^{\circ}$ & $\begin{array}{l}\text { Bank } \\
\text { height }\end{array}$ & $0.25 \times \mathrm{W}$ & N/A & Single & $\begin{array}{l}\text { Sediment heterogeneity had an effect } \\
\text { on localized scour depth and sedi- } \\
\text { ment sorting around spur }\end{array}$ \\
\hline $\begin{array}{l}\text { Teraguchi } \\
\text { et al. (2011) }\end{array}$ & $\begin{array}{c}\text { Bank } \\
\text { erosion and } \\
\text { bedload } \\
\end{array}$ & Site & $\begin{array}{c}\text { Variable } \\
\text { flow }\end{array}$ & Straight & $\begin{array}{l}\text { Narrow to } \\
\text { moderate }\end{array}$ & Moderate & $\begin{array}{c}\text { Fixed bank, } \\
\text { nonuniform } \\
\text { mobile bed }\end{array}$ & $90^{\circ}$ & $\begin{array}{c}18 \% \text { of } \\
\text { bank } \\
\text { height }\end{array}$ & $0.19 \times \mathrm{W}$ & $2.5 \times \mathrm{L}$ & Multiple & $\begin{array}{l}\text { Erosion at tip and deposition along } \\
\text { bank were best with a hybrid of per- } \\
\text { meable and impermeable spurs. }\end{array}$ \\
\hline $\begin{array}{l}\text { Duan } \\
(2009)\end{array}$ & $\begin{array}{c}\text { Flow and } \\
\text { bedload }\end{array}$ & Site & $\begin{array}{c}\text { Single } \\
\text { event }\end{array}$ & Straight & Narrow & Low & $\begin{array}{l}\text { Fixed bank, } \\
\text { nonuniform } \\
\text { mobile bed }\end{array}$ & $90^{\circ}$ & $\begin{array}{c}\text { Bank } \\
\text { height }\end{array}$ & $0.33 \times \mathrm{W}$ & N/A & Single & $\begin{array}{l}\text { Two counter-rotating flow circula- } \\
\text { tions occurred at spur tip; bed shear } \\
\text { stress at spur tip was } 3 \times \text { the mean of } \\
\text { the approach flow. }\end{array}$ \\
\hline $\begin{array}{l}\text { Duan et al. } \\
\text { (2009) }\end{array}$ & $\begin{array}{c}\text { Flow and } \\
\text { bedload }\end{array}$ & Site & $\begin{array}{c}\text { Single } \\
\text { event }\end{array}$ & Straight & Narrow & Low & $\begin{array}{l}\text { Fixed bank, } \\
\text { nonuniform } \\
\text { mobile bed }\end{array}$ & $90^{\circ}$ & $\begin{array}{l}\text { Bank } \\
\text { height }\end{array}$ & $0.33 \times \mathrm{W}$ & N/A & Single & $\begin{array}{l}\text { Bed shear stress at spur tip could be } \\
\text { up to } 6 \times \text { to } 8 \times \text { higher than approach } \\
\text { flow. }\end{array}$ \\
\hline $\begin{array}{l}\text { Ghodsian and } \\
\text { Vaghefi } \\
\text { (2009) }\end{array}$ & $\begin{array}{c}\text { Flow and } \\
\text { bedload }\end{array}$ & Site & $\begin{array}{c}\text { Variable } \\
\text { flow }\end{array}$ & Meander & $\mathrm{N} / \mathrm{R}$ & $\mathrm{N} / \mathrm{R}$ & $\begin{array}{l}\text { Fixed bank, } \\
\text { uniform } \\
\text { mobile bed }\end{array}$ & $90^{\circ}$ & $\begin{array}{c}\text { Bank } \\
\text { height }\end{array}$ & $\begin{array}{c}0.1 \text { to } \\
0.25 \times \mathrm{W}\end{array}$ & N/A & Single & $\begin{array}{l}\text { Scour around T-shaped spurs in- } \\
\text { creased with length and Froude num- } \\
\text { ber; created upstream and down- } \\
\text { stream vortices. }\end{array}$ \\
\hline $\begin{array}{l}\text { Zhang and } \\
\text { Nakagawa } \\
\text { (2009) }\end{array}$ & $\begin{array}{c}\text { Flow and } \\
\text { bedload }\end{array}$ & Site & $\begin{array}{c}\text { Single } \\
\text { event }\end{array}$ & Straight & Narrow & Low & $\begin{array}{c}\text { Fixed bank, } \\
\text { uniform } \\
\text { mobile bed }\end{array}$ & $90^{\circ}$ & $\begin{array}{c}\text { Bank } \\
\text { height }\end{array}$ & $0.25 \times \mathrm{W}$ & N/A & Single & $\begin{array}{l}\text { Permeable spurs reduced velocities } \\
\text { and had less impact on flow structure } \\
\text { than impermeable spurs; recom- } \\
\text { mended a combination of both. }\end{array}$ \\
\hline $\begin{array}{c}\text { Fazli et al. } \\
\quad(2008)\end{array}$ & Bedload & Site & $\begin{array}{c}\text { Variable } \\
\text { flow }\end{array}$ & Meander & Narrow & $\mathrm{N} / \mathrm{R}$ & $\begin{array}{c}\text { Fixed bank, } \\
\text { uniform } \\
\text { mobile bed }\end{array}$ & $90^{\circ}$ & $\begin{array}{c}\text { Bank } \\
\text { height }\end{array}$ & $\begin{array}{c}0.1 \text { to } \\
0.2 \times W\end{array}$ & $\mathrm{~N} / \mathrm{A}$ & Single & $\begin{array}{l}\text { Developed an equation to predict } \\
\text { scour around spurs based on Froude } \\
\text { number, spur length, and location in } \\
\text { meander bend. }\end{array}$ \\
\hline $\begin{array}{l}\text { Koken and } \\
\text { Constantinescu } \\
(2008 b)\end{array}$ & $\begin{array}{c}\text { Flow and } \\
\text { bedload }\end{array}$ & Site & $\begin{array}{c}\text { Single } \\
\text { event }\end{array}$ & Straight & Narrow & $\mathrm{N} / \mathrm{R}$ & $\begin{array}{l}\text { Fixed bank, } \\
\text { mobile bed }\end{array}$ & $90^{\circ}$ & $\begin{array}{c}\text { Bank } \\
\text { height }\end{array}$ & $0.16 \times \mathrm{W}$ & N/A & Single & $\begin{array}{l}\text { Observed and measured time-de- } \\
\text { pendent vortices in the region of the } \\
\text { spur and how vortices affected scour } \\
\text { and deposition. }\end{array}$ \\
\hline $\begin{array}{l}\text { Nasrollahi } \\
\text { et al. (2008) }\end{array}$ & Bedload & Site & $\begin{array}{c}\text { Single } \\
\text { event }\end{array}$ & Straight & Moderate & $\mathrm{N} / \mathrm{R}$ & $\begin{array}{l}\text { Fixed bank, } \\
\text { mobile bed }\end{array}$ & $90^{\circ}$ & $\begin{array}{c}\text { Bank } \\
\text { height }\end{array}$ & $\begin{array}{c}0.13 \text { to } \\
0.38 \times \mathrm{W}\end{array}$ & N/A & Single & $\begin{array}{l}\text { Developed equations to estimate var- } \\
\text { iations in scour depth; short imper- } \\
\text { meable spurs or permeable spurs re- } \\
\text { sulted in the least scour. }\end{array}$ \\
\hline $\begin{array}{l}\text { Uijttewaal } \\
(2005)\end{array}$ & Flow & Site & $\begin{array}{l}\text { Single } \\
\text { event }\end{array}$ & Straight & Moderate & $\mathrm{N} / \mathrm{R}$ & $\begin{array}{c}\text { Fixed bank } \\
\text { and bed }\end{array}$ & $90^{\circ}$ & $\begin{array}{c}\text { Bank } \\
\text { height }\end{array}$ & $0.40 \times \mathrm{W}$ & $2.25 \times \mathrm{L}$ & Multiple & $\begin{array}{l}\text { Measured 3D flow effects of imper- } \\
\text { meable and permeable spurs, weirs, } \\
\text { and vanes; structure submergence } \\
\text { had the greatest effect. }\end{array}$ \\
\hline $\begin{array}{l}\text { Ettema and } \\
\text { Muste (2004) }\end{array}$ & Flow & Site & $\begin{array}{c}\text { Single } \\
\text { event }\end{array}$ & Straight & Narrow & Moderate & $\begin{array}{c}\text { Fixed bank } \\
\text { and bed }\end{array}$ & $90^{\circ}$ & $\begin{array}{c}\text { Bank } \\
\text { height }\end{array}$ & $0.33 \times \mathrm{W}$ & N/A & Single & $\begin{array}{l}\text { Flow distortions observed when } \\
\text { comparing flow features between } \\
\text { small versus model length scales. }\end{array}$ \\
\hline $\begin{array}{l}\text { Giri et al. } \\
\text { (2004) }\end{array}$ & Flow & Reach & $\begin{array}{l}\text { Single } \\
\text { event }\end{array}$ & Meander & Narrow & $\mathrm{N} / \mathrm{R}$ & $\begin{array}{c}\text { Fixed bank } \\
\text { and bed }\end{array}$ & $90^{\circ}$ & $\begin{array}{c}\text { Bank } \\
\text { height }\end{array}$ & $0.25 \times \mathrm{W}$ & $3 \times \mathrm{L}$ & Multiple & $\begin{array}{l}\text { Measured hydraulic effects of spurs } \\
\text { and calibrated a 2D numerical model } \\
\text { with the results. }\end{array}$ \\
\hline $\begin{array}{l}\text { Giri et al. } \\
\text { (2003) }\end{array}$ & Flow & Reach & $\begin{array}{c}\text { Single } \\
\text { event }\end{array}$ & Meander & Narrow & Low & $\begin{array}{l}\text { Fixed bank } \\
\text { and bed }\end{array}$ & $90^{\circ}$ & $\begin{array}{c}\text { Bank } \\
\text { height }\end{array}$ & $0.25 \times \mathrm{W}$ & $3 \times \mathrm{L}$ & Multiple & $\begin{array}{l}\text { Installation of spurs redistributed ve- } \\
\text { locity along downstream meander by } \\
\text { creating a dead zone. }\end{array}$ \\
\hline $\begin{array}{l}\text { Sukhodolov } \\
\text { et al. (2002) }\end{array}$ & $\begin{array}{l}\text { Flow and } \\
\text { sediment } \\
\text { transport }\end{array}$ & Site & $\begin{array}{c}\text { Single } \\
\text { event }\end{array}$ & Straight & Moderate & $\mathrm{N} / \mathrm{R}$ & $\begin{array}{c}\text { Fixed bank } \\
\text { and bed }\end{array}$ & $90^{\circ}$ & $\begin{array}{c}\text { Bank } \\
\text { height }\end{array}$ & $0.25 \times \mathrm{W}$ & $\begin{array}{l}1.4 \text { to } \\
5 \times \mathrm{L}\end{array}$ & Multiple & $\begin{array}{l}\text { Two 2D eddies formed between } \\
\text { spurs spaced at least twice their } \\
\text { length apart; deposition between } \\
\text { spurs depended on eddy velocities. }\end{array}$ \\
\hline $\begin{array}{l}\text { Uijttewaal } \\
\text { et al. (2001) }\end{array}$ & Flow & Site & $\begin{array}{c}\text { Variable } \\
\text { flow }\end{array}$ & Straight & Moderate & $\mathrm{N} / \mathrm{R}$ & $\begin{array}{c}\text { Fixed bank } \\
\text { and bed }\end{array}$ & $90^{\circ}$ & $\begin{array}{c}\text { Bank } \\
\text { height }\end{array}$ & $0.25 \times \mathrm{W}$ & $\begin{array}{c}1.4 \text { to } \\
3.3 \times \mathrm{L}\end{array}$ & Multiple & $\begin{array}{l}\text { Exchange of dissolved matter oc- } \\
\text { curred along a mixing layer at the } \\
\text { river and spur interface. }\end{array}$ \\
\hline $\begin{array}{c}\text { Rahman and } \\
\text { Muramoto } \\
\text { (1999) }\end{array}$ & Bedload & Site & $\begin{array}{c}\text { Variable } \\
\text { flow }\end{array}$ & Straight & Narrow & $\mathrm{N} / \mathrm{R}$ & $\begin{array}{l}\text { Fixed bank, } \\
\text { mobile bed }\end{array}$ & $90^{\circ}$ & $\begin{array}{c}\text { Bank } \\
\text { height }\end{array}$ & $\begin{array}{c}0.13 \text { to } \\
0.28 \times \mathrm{W}\end{array}$ & N/A & Single & $\begin{array}{l}\text { Developed an equation to predict } \\
\text { scour around spurs. }\end{array}$ \\
\hline
\end{tabular}

[a] "Single event" indicates that one discharge was tested, and "Variable flow" indicates that two or more discharges were tested as steady, uniform events.

[b] $\mathrm{W} / \mathrm{D}=$ channel width-to-depth ratio $:<12=$ narrow,$<40=$ moderate, and $>40=$ wide.

(b] $/ \mathrm{D}=$ channel width-to-depth ratio: $<12=$ narrow, $<40=$ moderate,
[c] $\left.\mathrm{m} \mathrm{m}^{-1}\right):<0.001=$ low, $<0.04=$ moderate, and $>0.04=$ high.

[c] Slope $\left(\mathrm{m} \mathrm{m}^{-1}\right):<0.001=$ low, $<0.04=$ moderate, and $>0.04=$ high.
[d] Angle $=$ angle from upstream bank line tangent, $\mathrm{H}=$ height of structure, and $\mathrm{L}=$ length

[e] Single $=$ one single-wing deflector, and Multiple $=$ many single-wing deflectors. 
Table A2. Summary of impermeable spur field studies (1998-2019) $(\mathrm{N} / \mathrm{A}=$ not applicable; $\mathrm{N} / \mathrm{R}=$ not reported).

\begin{tabular}{|c|c|c|c|c|c|c|c|c|c|c|c|c|c|}
\hline \multirow[b]{2}{*}{ Study } & \multirow[b]{2}{*}{ Objective } & \multirow{2}{*}{$\begin{array}{c}\text { Spatial } \\
\text { Scale }\end{array}$} & \multirow{2}{*}{$\begin{array}{c}\text { Time } \\
\text { Scale }^{[a]}\end{array}$} & \multicolumn{4}{|c|}{ Channel Conditions } & \multicolumn{5}{|c|}{ Structure Properties ${ }^{[d]}$} & \multirow[b]{2}{*}{ Results } \\
\hline & & & & Planform & $\mathrm{W} / \mathrm{D}^{[\mathrm{b}]}$ & Slope ${ }^{[\mathrm{c}]}$ & Boundaries & Angle & $\mathrm{H}$ & $\mathrm{L}$ & Spacing & $\operatorname{Plan}^{[e]}$ & \\
\hline $\begin{array}{c}\text { Acharya and } \\
\text { Gautam (2012) }\end{array}$ & $\begin{array}{c}\text { Bank } \\
\text { erosion } \\
\text { and flow }\end{array}$ & Site & Short & Natural & $\mathrm{N} / \mathrm{R}$ & $\mathrm{N} / \mathrm{R}$ & Natural & $90^{\circ}$ & $\begin{array}{l}\text { Up to } \\
\text { bank } \\
\text { height }\end{array}$ & $\mathrm{N} / \mathrm{R}$ & $\mathrm{N} / \mathrm{R}$ & Multiple & $\begin{array}{l}\text { Bendway weirs slowed velocity and } \\
\text { induced deposition on protected bank } \\
\text { region better than spurs or toe rock. }\end{array}$ \\
\hline $\begin{array}{l}\text { Radspinner } \\
\text { et al. (2010) }\end{array}$ & $\begin{array}{c}\text { Bank } \\
\text { erosion, } \\
\text { bedload, } \\
\text { and habitat }\end{array}$ & $\begin{array}{l}\text { Site to } \\
\text { reach }\end{array}$ & $\mathrm{N} / \mathrm{R}$ & Natural & $\begin{array}{l}\text { Narrow to } \\
\text { moderate }\end{array}$ & $\begin{array}{l}\text { Low to } \\
\text { moderate }\end{array}$ & Natural & $\mathrm{N} / \mathrm{R}$ & $\mathrm{N} / \mathrm{R}$ & $\mathrm{N} / \mathrm{R}$ & $N / R$ & $\mathrm{~N} / \mathrm{R}$ & $\begin{array}{l}\text { Impermeable spurs, bendway weirs, } \\
\text { or rock vanes may perform better in } \\
\text { higher W/D channels with multiple } \\
\text { structures. }\end{array}$ \\
\hline $\begin{array}{l}\text { Wu et al. } \\
(2005)\end{array}$ & $\begin{array}{l}\text { Bank } \\
\text { erosion and } \\
\text { bedload }\end{array}$ & $\begin{array}{l}\text { Reach } \\
\text { to river }\end{array}$ & Long & Natural & Wide & Low & Natural & $\begin{array}{l}90^{\circ} \\
\text { to } 150^{\circ}\end{array}$ & $\begin{array}{c}\text { Bank } \\
\text { height }\end{array}$ & $\begin{array}{c}0.05 \text { to } \\
0.33 \times \mathrm{W}\end{array}$ & $1 \times \mathrm{L}$ & Multiple & $\begin{array}{l}\text { Spurs were effective at reducing } \\
\text { bank erosion; treating } 80 \% \text { of river } \\
\text { length can shift stream from braided } \\
\text { to confined and meandering. }\end{array}$ \\
\hline $\begin{array}{l}\text { Rahman and } \\
\text { Haque (2004) }\end{array}$ & Bedload & Site & Short & Natural & Wide & Low & Natural & $90^{\circ}$ & $\begin{array}{c}\text { Bank } \\
\text { height }\end{array}$ & $\mathrm{N} / \mathrm{R}$ & $\mathrm{N} / \mathrm{A}$ & Single & $\begin{array}{l}\text { Developed spur sideslope adjustment } \\
\text { of Melville's (1992) scour prediction } \\
\text { formulas based on field data. }\end{array}$ \\
\hline $\begin{array}{l}\text { Engelhardt } \\
\text { et al. (2004) }\end{array}$ & $\begin{array}{l}\text { Flow, } \\
\text { suspended } \\
\text { load, and } \\
\text { habitat }\end{array}$ & Site & Short & Natural & Wide & $\mathrm{N} / \mathrm{R}$ & Natural & $\mathrm{N} / \mathrm{R}$ & $\mathrm{N} / \mathrm{R}$ & $\mathrm{N} / \mathrm{R}$ & $N / R$ & $\begin{array}{l}\text { Double } \\
\text { multiple }\end{array}$ & $\begin{array}{l}\text { Spacing between spurs had an effect } \\
\text { on flow patterns, residence times, } \\
\text { and organic matter content. }\end{array}$ \\
\hline $\begin{array}{l}\text { Sukhodolov } \\
\text { et al. (2004) }\end{array}$ & $\begin{array}{l}\text { Flow and } \\
\text { suspended } \\
\text { load }\end{array}$ & Site & Short & Natural & Wide & $\mathrm{N} / \mathrm{R}$ & Natural & $90^{\circ}$ & $\begin{array}{c}\text { Bank } \\
\text { height }\end{array}$ & $0.2 \times W$ & $\begin{array}{r}2 \text { to } \\
3 \times \mathrm{L}\end{array}$ & $\begin{array}{l}\text { Double } \\
\text { multiple }\end{array}$ & $\begin{array}{l}\text { Suspended sediment decreased to- } \\
\text { ward the bank; velocities increased } \\
\text { and then decreased from channel } \\
\text { bottom to free surface. }\end{array}$ \\
\hline $\begin{array}{l}\text { Ten Brinke } \\
\text { et al. (2004) }\end{array}$ & Bedload & $\begin{array}{l}\text { Reach } \\
\text { to river }\end{array}$ & Long & Natural & Wide & Low & Natural & $90^{\circ}$ & $\begin{array}{l}\text { Bank } \\
\text { height }\end{array}$ & $\begin{array}{l}0.15 \text { to } \\
0.2 \times W\end{array}$ & $4 \times \mathrm{L}$ & $\begin{array}{l}\text { Double } \\
\text { multiple }\end{array}$ & $\begin{array}{l}\text { Spur fields alternated between peri- } \\
\text { ods of erosion and deposition; ero- } \\
\text { sion was caused by navigation; depo- } \\
\text { sition was caused by floods. } \\
\end{array}$ \\
\hline $\begin{array}{l}\text { Schwartz and } \\
\text { Kozerski } \\
(2003)\end{array}$ & $\begin{array}{c}\text { Sediment } \\
\text { transport } \\
\text { and habitat }\end{array}$ & Site & Medium & Natural & Wide & Moderate & Natural & $90^{\circ}$ & $\mathrm{N} / \mathrm{R}$ & $\begin{array}{c}0.10 \text { to } \\
0.35 \times \mathrm{W}\end{array}$ & $1-1.5 \times \mathrm{L}$ & $\begin{array}{l}\text { Double } \\
\text { multiple }\end{array}$ & $\begin{array}{l}\text { Spur field deposits contained sedi- } \\
\text { ment-laden pollutants that could eas- } \\
\text { ily be remobilized during times of } \\
\text { high turbulence. }\end{array}$ \\
\hline $\begin{array}{ll}\text { [a] } & \text { Time scale: } \\
\text { [b] } & \text { W/D }=\text { chan } \\
\text { [c] } & \text { Slope }\left(\mathrm{m} \mathrm{m}^{-}\right. \\
\text {[d] } & \text { Angle = ang } \\
\text { [c] } & \text { Single }=\text { one }\end{array}$ & $\begin{array}{l}\text { thel width-to-c } \\
-1 \text { ): }<0.001=1 \\
\text { gle from upstre }\end{array}$ & low, $<0.0$ & $\begin{array}{l}4=\text { moder } \\
\text { line tang } \\
\text {, Multiple }\end{array}$ & $\begin{array}{l}\mathrm{e}, \text { and }>0 . \\
\mathrm{t}, \mathrm{H}=\text { heig }\end{array}$ & $\begin{array}{l}\text { loderate, a } \\
\text { = high. } \\
\text { of structur }\end{array}$ & $\mathrm{d} L=\mathrm{le}$ & & & & & & & \\
\hline
\end{tabular}

Table A3. Summary of impermeable spur numerical models (1998-2019) $(\mathrm{N} / \mathrm{A}=$ not applicable; $\mathrm{N} / \mathrm{R}=$ not reported).

\begin{tabular}{|c|c|c|c|c|c|c|c|c|c|c|c|c|c|}
\hline \multirow[b]{2}{*}{ Study } & \multirow[b]{2}{*}{ Objective } & \multirow{2}{*}{$\begin{array}{l}\text { Spatial } \\
\text { Scale }\end{array}$} & \multirow{2}{*}{$\begin{array}{l}\text { Time } \\
\text { Scale }\end{array}$} & \multicolumn{4}{|c|}{ Channel Conditions } & \multicolumn{5}{|c|}{ Structure Properties ${ }^{[\mathrm{c}]}$} & \multirow[b]{2}{*}{ Results ${ }^{[e]}$} \\
\hline & & & & Planform & $\mathrm{W} / \mathrm{D}^{[\mathrm{a}]}$ & Slope $^{[\mathrm{b}]}$ & Boundaries & Angle & $\mathrm{H}$ & $\mathrm{L}$ & Spacing & Plan $^{[\mathrm{d}]}$ & \\
\hline $\begin{array}{l}\text { Koken and } \\
\text { Gogus (2015) }\end{array}$ & Flow & Site & $\begin{array}{l}\text { Single } \\
\text { event }\end{array}$ & Straight & Narrow & $\mathrm{N} / \mathrm{R}$ & $\begin{array}{l}\text { Fixed bank, } \\
\text { uniform } \\
\text { mobile bed }\end{array}$ & $90^{\circ}$ & $\begin{array}{l}\text { Bank } \\
\text { height }\end{array}$ & $\begin{array}{c}0.1 \text { to } \\
0.23 \times \mathrm{W}\end{array}$ & N/A & Single & $\begin{array}{l}\text { 3D (DES) model showed that longer } \\
\text { spurs locally increased bed shear } \\
\text { stress, pressure, and main horseshoe } \\
\text { vortex length. }\end{array}$ \\
\hline $\begin{array}{l}\text { Koken } \\
(2011)\end{array}$ & Flow & Site & $\begin{array}{l}\text { Single } \\
\text { event }\end{array}$ & Straight & Narrow & $\mathrm{N} / \mathrm{R}$ & $\begin{array}{l}\text { Fixed bank } \\
\text { and bed }\end{array}$ & $\begin{array}{l}60^{\circ} \\
\text { to } 120^{\circ}\end{array}$ & $\begin{array}{l}\text { Bank } \\
\text { height }\end{array}$ & $0.23 \times \mathrm{W}$ & N/A & Single & $\begin{array}{l}\text { 3D (LES) model showed that size } \\
\text { and orientation of horseshoe vortex } \\
\text { was affected by spur angle; } 90^{\circ} \text { spur } \\
\text { created the most shear stress. }\end{array}$ \\
\hline $\begin{array}{l}\text { Zhang et al. } \\
\text { (2009) }\end{array}$ & $\begin{array}{l}\text { Flow and } \\
\text { bedload }\end{array}$ & Site & $\begin{array}{l}\text { Single } \\
\text { event }\end{array}$ & Straight & Narrow & Low & $\begin{array}{c}\text { Fixed bank, } \\
\text { uniform } \\
\text { mobile bed }\end{array}$ & $90^{\circ}$ & $\begin{array}{l}\text { Bank } \\
\text { height }\end{array}$ & $0.25 \times \mathrm{W}$ & N/A & Single & $\begin{array}{l}\text { Calibrated a 3D }(k-\varepsilon) \text { model to ana- } \\
\text { lyze flow and scour near a spur. }\end{array}$ \\
\hline $\begin{array}{l}\text { Koken and } \\
\text { Constantinescu } \\
(2008 \mathrm{a})\end{array}$ & $\begin{array}{l}\text { Flow and } \\
\text { bedload }\end{array}$ & Site & $\begin{array}{l}\text { Single } \\
\text { event }\end{array}$ & Straight & Narrow & $N / R$ & $\begin{array}{l}\text { Fixed bank, } \\
\text { nonuniform } \\
\text { mobile bed }\end{array}$ & $90^{\circ}$ & $\begin{array}{l}\text { Bank } \\
\text { height }\end{array}$ & $0.16 \times W$ & N/A & Single & $\begin{array}{l}\text { 3D (LES) model showed that vorti- } \\
\text { ces formed by spur caused scour hole } \\
\text { at tip to grow; entrained sediment } \\
\text { was deposited in wake. }\end{array}$ \\
\hline $\begin{array}{l}\text { McCoy et al. } \\
\quad(2008)\end{array}$ & Flow & Site & $\begin{array}{l}\text { Single } \\
\text { event }\end{array}$ & Straight & Moderate & $\mathrm{N} / \mathrm{R}$ & $\begin{array}{l}\text { Fixed bank } \\
\text { and bed }\end{array}$ & $90^{\circ}$ & $\begin{array}{l}\text { Bank } \\
\text { height }\end{array}$ & $7.5 \times \mathrm{D}$ & $10.75 \times \mathrm{D}$ & Multiple & $\begin{array}{l}\text { 3D (LES) model showed that flow } \\
\text { between spurs was } 2 \mathrm{D} \text {; flow at tip } \\
\text { was 3D; explained exchange be- } \\
\text { tween channel and wake region. }\end{array}$ \\
\hline $\begin{array}{c}\text { Duan and } \\
\text { Nanda (2006) }\end{array}$ & $\begin{array}{c}\text { Flow and } \\
\text { suspended } \\
\text { load }\end{array}$ & Site & $\begin{array}{c}\text { Single } \\
\text { event }\end{array}$ & Meander & $\mathrm{N} / \mathrm{R}$ & $\mathrm{N} / \mathrm{R}$ & $\begin{array}{l}\text { Fixed bank, } \\
\text { nonuniform } \\
\text { mobile bed }\end{array}$ & $90^{\circ}$ & $\begin{array}{l}\text { Bank } \\
\text { height }\end{array}$ & $\begin{array}{l}0.25 \text { to } \\
0.5 \times W\end{array}$ & $\mathrm{~N} / \mathrm{R}$ & Multiple & $\begin{array}{l}\text { 2D model showed that spurs in- } \\
\text { creased suspended sediment concen- } \\
\text { tration near tip. }\end{array}$ \\
\hline $\begin{array}{l}\text { Nagata et al. } \\
\quad(2005)\end{array}$ & $\begin{array}{l}\text { Flow and } \\
\text { bedload }\end{array}$ & Site & $\begin{array}{l}\text { Variable } \\
\text { flow }\end{array}$ & Straight & $\begin{array}{l}\text { Narrow to } \\
\text { moderate }\end{array}$ & $\begin{array}{l}\text { Low to } \\
\text { moderate }\end{array}$ & $\begin{array}{l}\text { Fixed bank, } \\
\text { fixed and } \\
\text { mobile bed }\end{array}$ & $90^{\circ}$ & $\begin{array}{l}\text { Bank } \\
\text { height }\end{array}$ & $0.25 \times \mathrm{W}$ & N/A & Single & $\begin{array}{l}\text { Calibrated a 3D }(k-\varepsilon) \text { model to ana- } \\
\text { lyze flow and scour near a spur. }\end{array}$ \\
\hline $\begin{array}{l}\text { Kothyari and } \\
\text { Ranga Raju } \\
(2001) \\
\end{array}$ & Bedload & Site & $\begin{array}{l}\text { Variable } \\
\text { flow }\end{array}$ & Straight & $\begin{array}{l}\text { Narrow to } \\
\text { wide }\end{array}$ & $\mathrm{N} / \mathrm{R}$ & $\begin{array}{c}\text { Fixed bank, } \\
\text { uniform } \\
\text { mobile bed }\end{array}$ & $90^{\circ}$ & $\begin{array}{l}\text { Bank } \\
\text { height }\end{array}$ & $\begin{array}{l}0.04 \text { to } \\
0.58 \times \mathrm{W}\end{array}$ & N/A & Single & $\begin{array}{l}\text { Developed scour prediction equa- } \\
\text { tions based on results of numerous } \\
\text { studies. }\end{array}$ \\
\hline
\end{tabular}

[a] $\mathrm{W} / \mathrm{D}=$ channel width-to-depth ratio: $<12=$ narrow, $<40=$ moderate, and $>40=$ wide

[b] Slope $\left(\mathrm{m} \mathrm{m}^{-1}\right):<0.001=$ low, $<0.04=$ moderate, and $>0.04=$ high.

[c] Angle = angle from upstream bank line tangent, $\mathrm{H}=$ height of structure, and $\mathrm{L}=$ length.

[d] Single $=$ one single-wing deflector, and Multiple $=$ many single-wing deflectors.

[e] DES = Detached eddy simulation, and LES = Large eddy simulation. 
Table A4. Summary of bendway weir physical models (1998-2019) $(\mathrm{N} / \mathrm{A}=$ not applicable; $\mathrm{N} / \mathrm{R}=$ not reported).

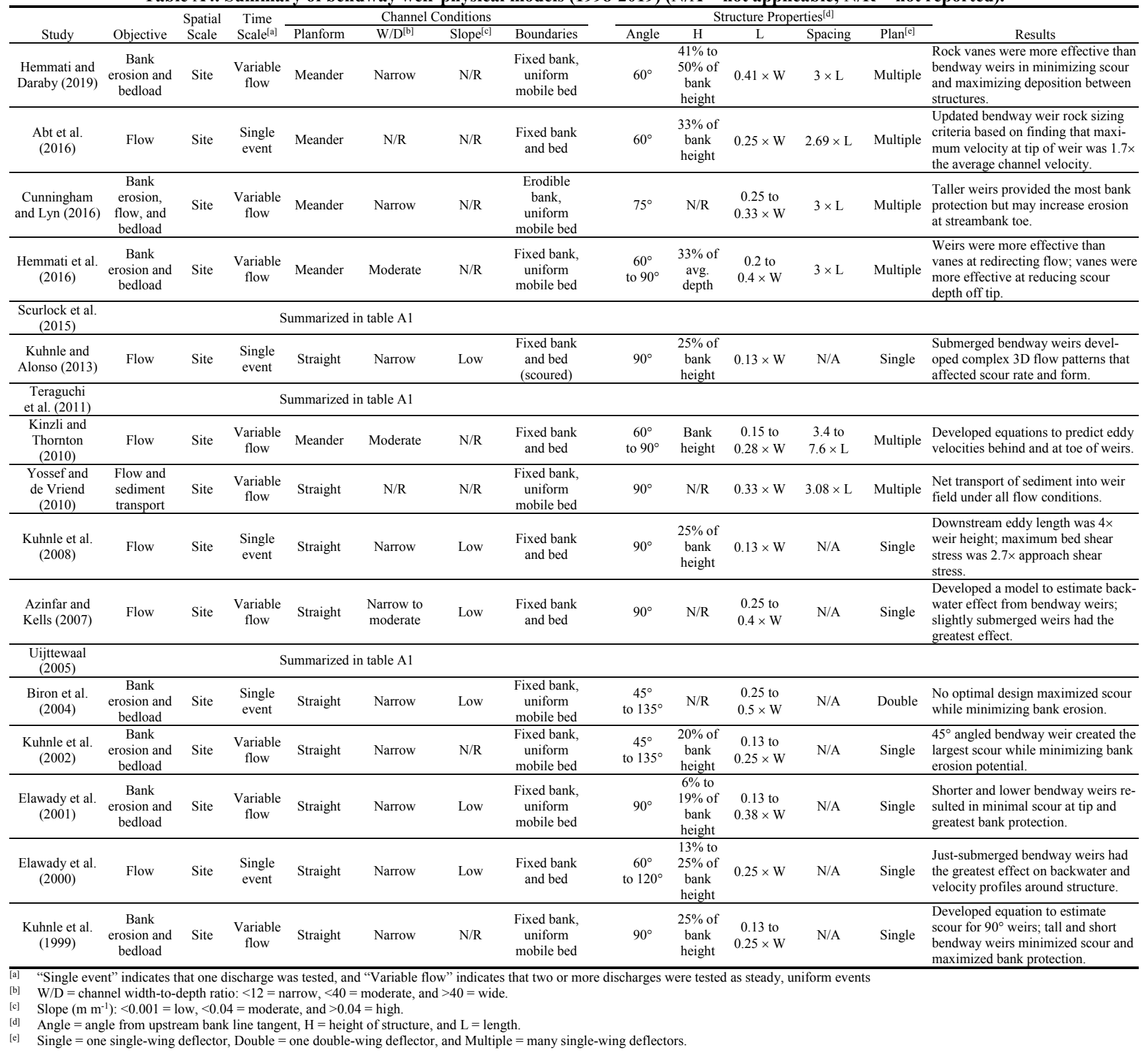


Table A5. Summary of bendway weir field studies (1998-2019) $(\mathrm{N} / \mathrm{R}=$ not reported).

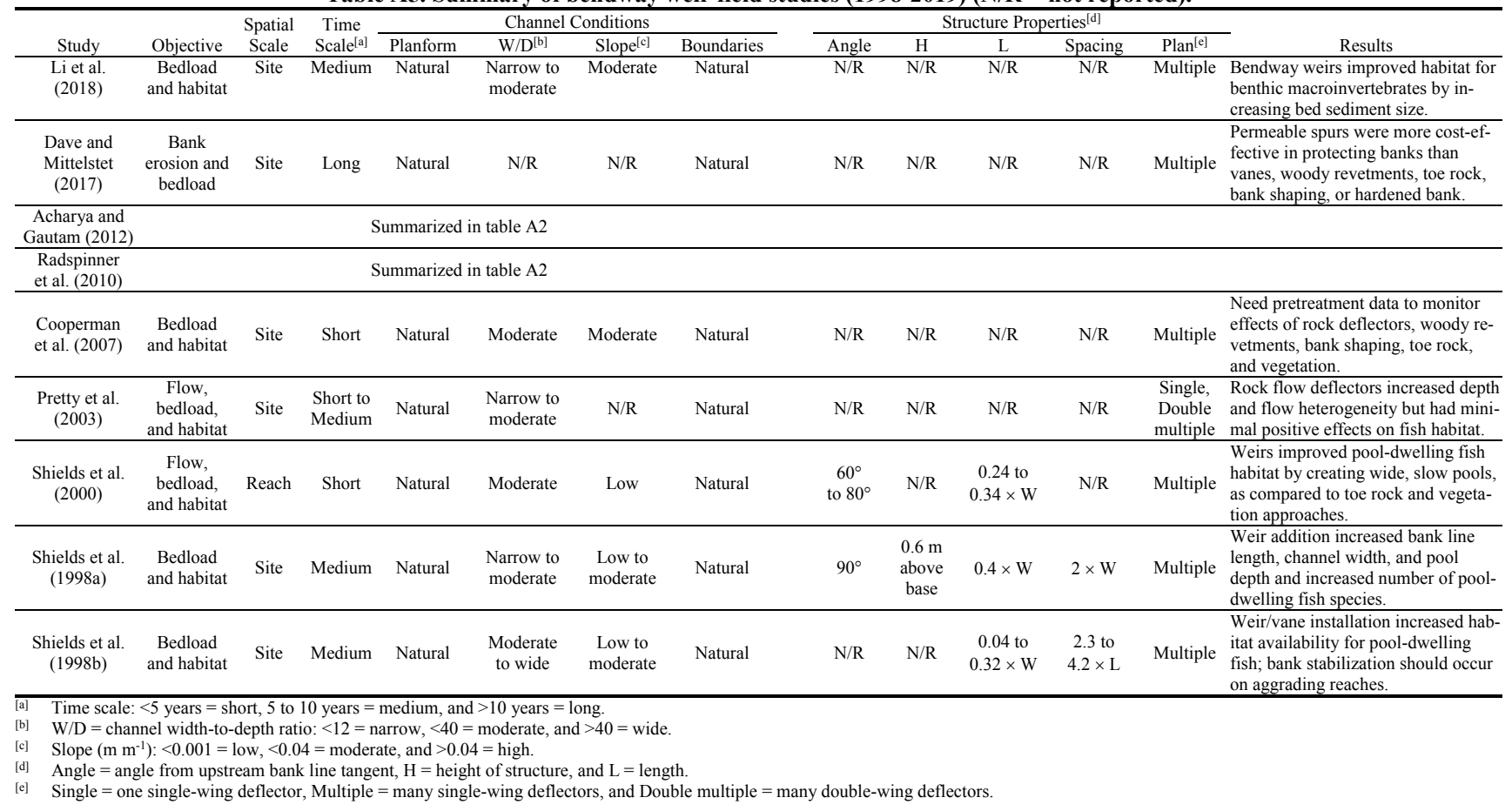

Table A6. Summary of bendway weir numerical models (1998-2019) (N/A = not applicable; $N / R=$ not reported).

\begin{tabular}{|c|c|c|c|c|c|c|c|c|c|c|c|c|c|}
\hline \multirow[b]{2}{*}{ Study } & \multirow[b]{2}{*}{ Objective } & \multirow{2}{*}{$\begin{array}{c}\text { Spatial } \\
\text { Scale }\end{array}$} & \multirow{2}{*}{$\begin{array}{l}\text { Time } \\
\text { Scale }\end{array}$} & \multicolumn{4}{|c|}{ Channel Conditions } & \multicolumn{5}{|c|}{ Structure Properties ${ }^{[\mathrm{c}]}$} & \multirow[b]{2}{*}{$\operatorname{Results}^{[\mathrm{e}]}$} \\
\hline & & & & Planform & $\mathrm{W} / \mathrm{D}^{[\mathrm{a}]}$ & Slope $^{[\mathrm{b}]}$ & Boundaries & Angle & $\mathrm{H}$ & L & Spacing & Plan[d] & \\
\hline $\begin{array}{l}\text { Khosronejad } \\
\text { et al. (2017) }\end{array}$ & $\begin{array}{l}\text { Bank } \\
\text { erosion, } \\
\text { flow, and } \\
\text { bedload }\end{array}$ & Reach & $\begin{array}{c}\text { Single } \\
\text { event }\end{array}$ & Meander & Narrow & $\begin{array}{l}\text { Low to } \\
\text { moderate }\end{array}$ & $\begin{array}{l}\text { Fixed bank, } \\
\text { nonuniform } \\
\text { mobile bed }\end{array}$ & $\begin{array}{l}20^{\circ} \\
\text { to } 80^{\circ}\end{array}$ & $\begin{array}{l}50 \% \text { of } \\
\text { bank } \\
\text { height }\end{array}$ & $0.25 \times W$ & $\begin{array}{c}\text { Based on } \\
\text { model }\end{array}$ & Multiple & $\begin{array}{l}\text { VSL3D code (3D } k \text { - } \omega) \text { showed that } \\
50^{\circ} \text { weirs starting at meander apex } \\
\text { maximized bank protection and min- } \\
\text { imized bar erosion. }\end{array}$ \\
\hline $\begin{array}{l}\text { Elhakeem } \\
\text { et al. (2017) }\end{array}$ & $\begin{array}{l}\text { Bank } \\
\text { erosion } \\
\text { and flow }\end{array}$ & Site & $\begin{array}{c}\text { Single } \\
\text { event }\end{array}$ & Meander & Moderate & Low & $\begin{array}{l}\text { Fixed bank, } \\
\text { fixed bed }\end{array}$ & $\begin{array}{l}65^{\circ} \\
\text { to } 90^{\circ}\end{array}$ & $\begin{array}{c}\text { 2-year } \\
\mathrm{RI}^{[\mathrm{f}]} \\
\text { height }\end{array}$ & $0.4 \times W$ & $\begin{array}{c}0.75 \text { to } \\
2 \times \mathrm{L}\end{array}$ & Multiple & $\begin{array}{l}\text { FESWMS model (2D) was used to } \\
\text { optimize and monitor bendway weir, } \\
\text { rock vane, and toe rock design; pro- } \\
\text { ject successful after ten years. }\end{array}$ \\
\hline $\begin{array}{l}\text { Bressan et al. } \\
\text { (2014) }\end{array}$ & $\begin{array}{l}\text { Bank } \\
\text { erosion } \\
\text { and flow }\end{array}$ & Site & $\begin{array}{c}\text { Variable } \\
\text { flow }\end{array}$ & Meander & Wide & Low & $\begin{array}{l}\text { Fixed bank, } \\
\text { nonuniform } \\
\text { mobile bed }\end{array}$ & $\mathrm{N} / \mathrm{R}$ & $\begin{array}{c}33 \% \text { to } \\
100 \% \\
\text { of bank } \\
\text { height }\end{array}$ & $0.25 \times W$ & $\begin{array}{c}4 \text { to } \\
5 \times \mathrm{L}\end{array}$ & Multiple & $\begin{array}{l}\text { FESWMS model (2D) found weir } \\
\text { and rock vane combination design } \\
\text { was more cost-effective than riprap } \\
\text { at reducing velocities near bank. }\end{array}$ \\
\hline $\begin{array}{l}\text { Khosronejad } \\
\text { et al. (2014a) }\end{array}$ & $\begin{array}{l}\text { Flow and } \\
\text { bedload }\end{array}$ & $\begin{array}{l}\text { Site to } \\
\text { reach }\end{array}$ & $\begin{array}{c}\text { Single } \\
\text { event }\end{array}$ & Meander & $\begin{array}{l}\text { Narrow to } \\
\text { moderate }\end{array}$ & Moderate & $\begin{array}{l}\text { Fixed bank, } \\
\text { nonuniform } \\
\text { mobile bed }\end{array}$ & $\mathrm{N} / \mathrm{R}$ & $\mathrm{N} / \mathrm{R}$ & $\mathrm{N} / \mathrm{R}$ & $\mathrm{N} / \mathrm{R}$ & Multiple & $\begin{array}{l}\text { VSL3D code (3D LES and } k-\omega) \text { used } \\
\text { to understand dune formation and its } \\
\text { effect on flow in meander bend with } \\
\text { weirs or vanes. }\end{array}$ \\
\hline $\begin{array}{l}\text { Papanicolaou } \\
\text { et al. (2011a) }\end{array}$ & $\begin{array}{c}\text { Bank } \\
\text { erosion } \\
\text { and flow }\end{array}$ & Site & $\begin{array}{l}\text { Single } \\
\text { event }\end{array}$ & Meander & Moderate & Low & $\begin{array}{l}\text { Fixed bank, } \\
\text { fixed bed }\end{array}$ & $\begin{array}{l}65^{\circ} \\
\text { to } 90^{\circ}\end{array}$ & $\begin{array}{l}75 \% \text { of } \\
\text { avg. flow } \\
\text { depth }\end{array}$ & $0.33 \times \mathrm{W}$ & $2 \times \mathrm{L}$ & Multiple & $\begin{array}{l}\text { Showed that FESWMS (2D) can ad- } \\
\text { equately model flow around bend- } \\
\text { way weirs and rock vanes. }\end{array}$ \\
\hline $\begin{array}{l}\text { Papanicolaou } \\
\text { et al. } \\
(2011 \mathrm{~b})\end{array}$ & $\begin{array}{l}\text { Flow, } \\
\text { bedload, } \\
\text { and habitat }\end{array}$ & Site & $\begin{array}{l}\text { Single } \\
\text { event }\end{array}$ & Meander & Wide & $\mathrm{N} / \mathrm{R}$ & $\begin{array}{l}\text { Fixed bank, } \\
\text { fixed bed }\end{array}$ & $\mathrm{N} / \mathrm{R}$ & $N / R$ & $\mathrm{~N} / \mathrm{R}$ & $\mathrm{N} / \mathrm{R}$ & Multiple & $\begin{array}{l}\text { FESWMS (2D) showed that notched } \\
\text { bendway weirs did not improve shal- } \\
\text { low water habitat by decreasing ve- } \\
\text { locity and depth. }\end{array}$ \\
\hline $\begin{array}{l}\text { Jia et al. } \\
(2009)\end{array}$ & Flow & Site & $\begin{array}{c}\text { Single } \\
\text { event }\end{array}$ & Meander & Moderate & $\mathrm{N} / \mathrm{R}$ & $\begin{array}{l}\text { Fixed bank, } \\
\text { nonuniform } \\
\text { mobile bed }\end{array}$ & $\begin{array}{l}69^{\circ} \\
\text { to } 76^{\circ}\end{array}$ & $\mathrm{N} / \mathrm{R}$ & $\mathrm{N} / \mathrm{R}$ & $\mathrm{N} / \mathrm{R}$ & Multiple & $\begin{array}{l}\text { CCHE3D (3D } k-\varepsilon) \text { found that } \\
\text { smaller angled weirs caused the least } \\
\text { disruption to helical flow in bends. }\end{array}$ \\
\hline $\begin{array}{l}\text { Tritthart et al. } \\
\text { (2009) }\end{array}$ & $\begin{array}{c}\text { Flow and } \\
\text { habitat }\end{array}$ & Reach & $\begin{array}{c}\text { Variable } \\
\text { flow }\end{array}$ & Meander & Wide & $\mathrm{N} / \mathrm{R}$ & $\begin{array}{l}\text { Fixed bank, } \\
\text { nonuniform } \\
\text { mobile bed }\end{array}$ & $\mathrm{N} / \mathrm{R}$ & $\begin{array}{l}\text { Avg. } \\
\text { flow } \\
\text { depth } \\
\text { height }\end{array}$ & $\mathrm{N} / \mathrm{R}$ & $\mathrm{N} / \mathrm{R}$ & Multiple & $\begin{array}{l}\text { 3D }(k-\varepsilon) \text { model showed the greatest } \\
\text { residence times and water age in } \\
\text { bendway weir field when weirs were } \\
\text { just submerged. }\end{array}$ \\
\hline $\begin{array}{c}\text { Abad et al. } \\
(2008)\end{array}$ & $\begin{array}{l}\text { Bank } \\
\text { erosion } \\
\text { and flow }\end{array}$ & Site & $\begin{array}{c}\text { Variable } \\
\text { flow }\end{array}$ & Meander & Moderate & $\mathrm{N} / \mathrm{R}$ & $\begin{array}{c}\text { Fixed bank } \\
\text { and bed }\end{array}$ & $\mathrm{N} / \mathrm{R}$ & $\mathrm{N} / \mathrm{R}$ & $\mathrm{N} / \mathrm{R}$ & $\mathrm{N} / \mathrm{R}$ & Multiple & $\begin{array}{l}\text { FLOW-3D 9.0 (3D } k-\varepsilon) \text { found that } \\
\text { submerged weirs caused higher shear } \\
\text { stress at bank, likely causing bank } \\
\text { erosion to occur. }\end{array}$ \\
\hline $\begin{array}{c}\text { Shih et al. } \\
\text { (2008) }\end{array}$ & $\begin{array}{c}\text { Flow and } \\
\text { habitat }\end{array}$ & Site & $\begin{array}{c}\text { Variable } \\
\text { flow }\end{array}$ & Meander & $\mathrm{N} / \mathrm{R}$ & Moderate & $\begin{array}{l}\text { Fixed bank } \\
\text { and bed }\end{array}$ & $90^{\circ}$ & $N / R$ & $\mathrm{~N} / \mathrm{R}$ & $\begin{array}{c}1.3 \text { to } 10.2 \\
\times \mathrm{L}\end{array}$ & Multiple & $\begin{array}{l}\text { NETSTARS and TABS-2 (2D) } \\
\text { showed that weirs improved fish } \\
\text { habitat by decreasing velocity and } \\
\text { increasing depth. }\end{array}$ \\
\hline $\begin{array}{l}\text { McCoy et al. } \\
\text { (2007) }\end{array}$ & Flow & Site & $\begin{array}{c}\text { Single } \\
\text { event }\end{array}$ & Straight & Narrow & $\mathrm{N} / \mathrm{R}$ & $\begin{array}{l}\text { Fixed bank } \\
\text { and bed }\end{array}$ & $90^{\circ}$ & $\begin{array}{c}\text { Avg. } \\
\text { flow } \\
\text { depth } \\
\text { height }\end{array}$ & $0.63 \times \mathrm{H}$ & $1.25 \times \mathrm{H}$ & Multiple & $\begin{array}{l}\text { 3D (LES) model showed that pollu- } \\
\text { tant movement in and out of bend- } \\
\text { way weir field was greatest when } \\
\text { weirs were submerged. }\end{array}$ \\
\hline $\begin{array}{l}\text { Jia et al. } \\
\text { (2005) }\end{array}$ & Flow & Site & $\begin{array}{l}\text { Variable } \\
\text { flow }\end{array}$ & Meander & Moderate & $\mathrm{N} / \mathrm{R}$ & $\begin{array}{c}\text { Fixed bank } \\
\text { and bed }\end{array}$ & $20^{\circ}$ & $\begin{array}{l}47 \% \text { of } \\
\text { flow } \\
\text { depth }\end{array}$ & $0.6 \times \mathrm{W}$ & N/A & Single & $\begin{array}{l}\text { CCHE3D (3D } k-\varepsilon) \text { showed that sub- } \\
\text { merged weirs diminished the helical } \\
\text { secondary currents found in meander } \\
\text { bends. }\end{array}$ \\
\hline
\end{tabular}

channel width-to-depth ratio: $<12=$ narrow, $<40=$ moderate, and $>40=$ wide.

[b] Slope $\left(\mathrm{m} \mathrm{m}^{-1}\right):<0.001=$ low, $<0.04=$ moderate, and $>0.04=$ high.

[c] Angle $=$ angle from upstream bank line tangent, $\mathrm{H}=$ height of structure, and $\mathrm{L}=$ length

[d] Single $=$ one single-wing deflector, and Multiple $=$ many single-wing deflectors.

[c] LES $=$ Large eddy simulation

[f] $\mathrm{RI}=$ return interval. 
Table A7. Summary of rock vane physical models (1998-2019) (N/A = not applicable; $N / R=$ not reported).

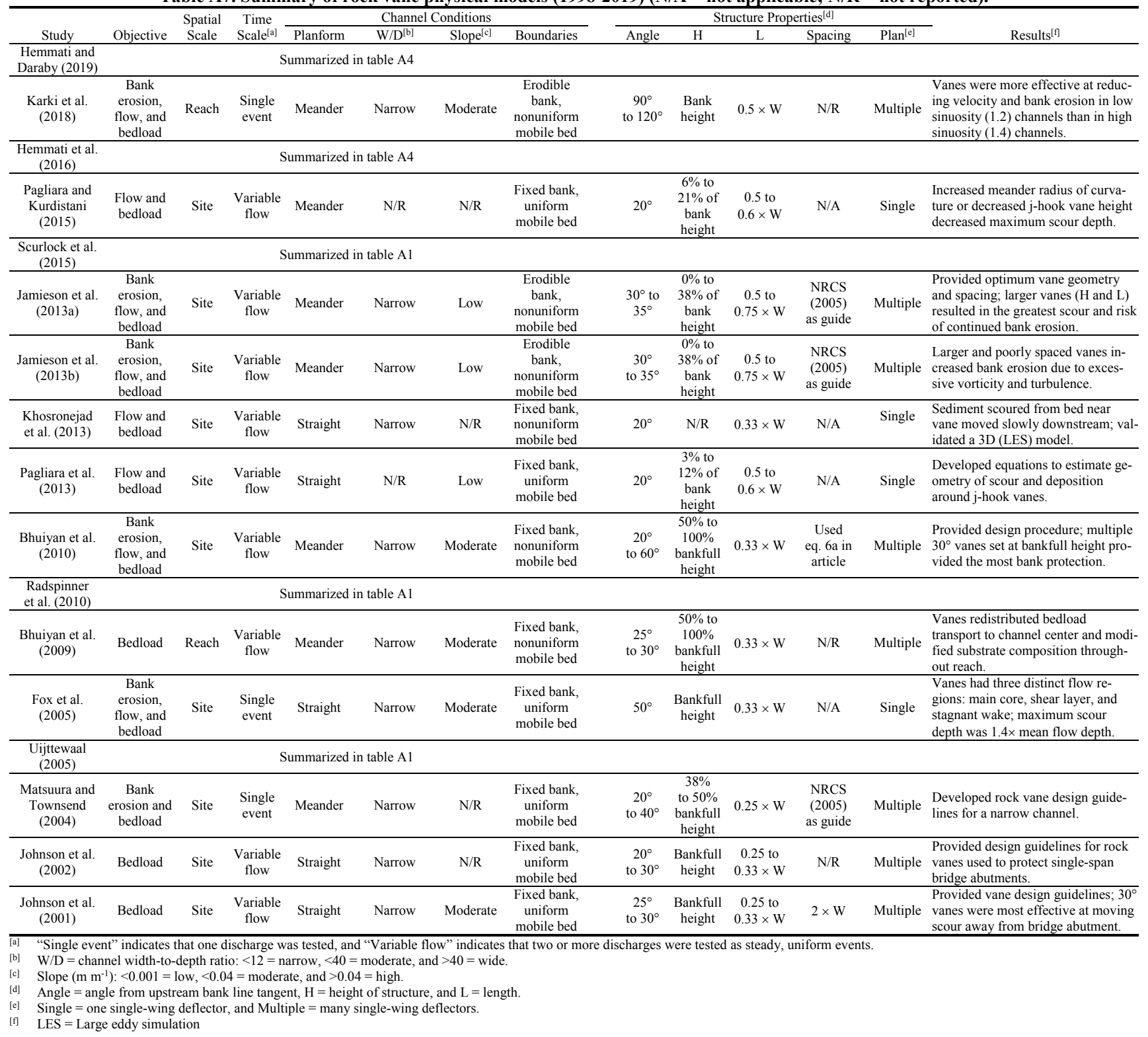


Table A8. Summary of rock vane field studies (1998-2019) $(\mathrm{N} / \mathrm{R}=$ not reported).

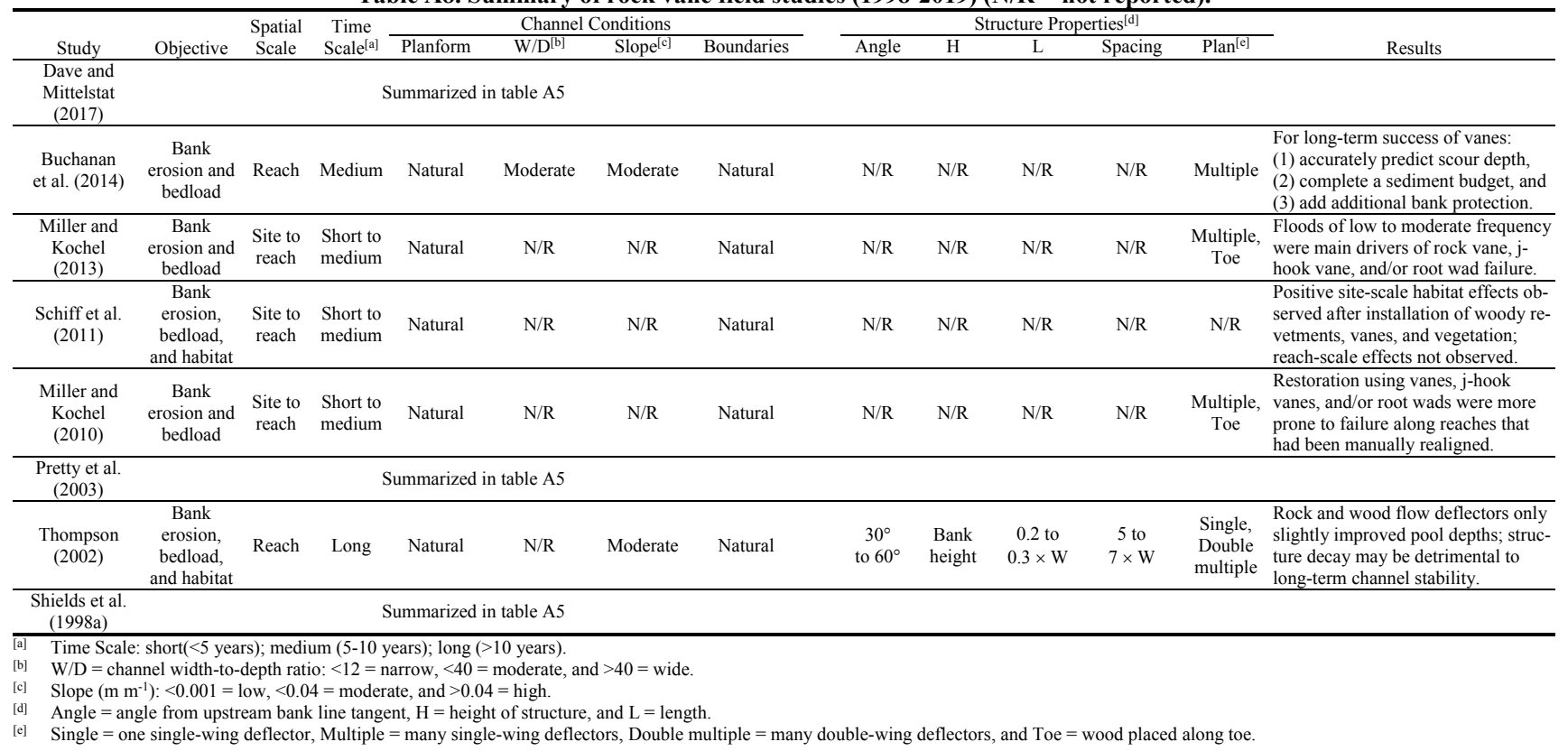

Table A9. Summary of rock vane numerical models (1998-2019) $(\mathrm{N} / \mathrm{A}=$ not applicable; $\mathrm{N} / \mathrm{R}=$ not reported).

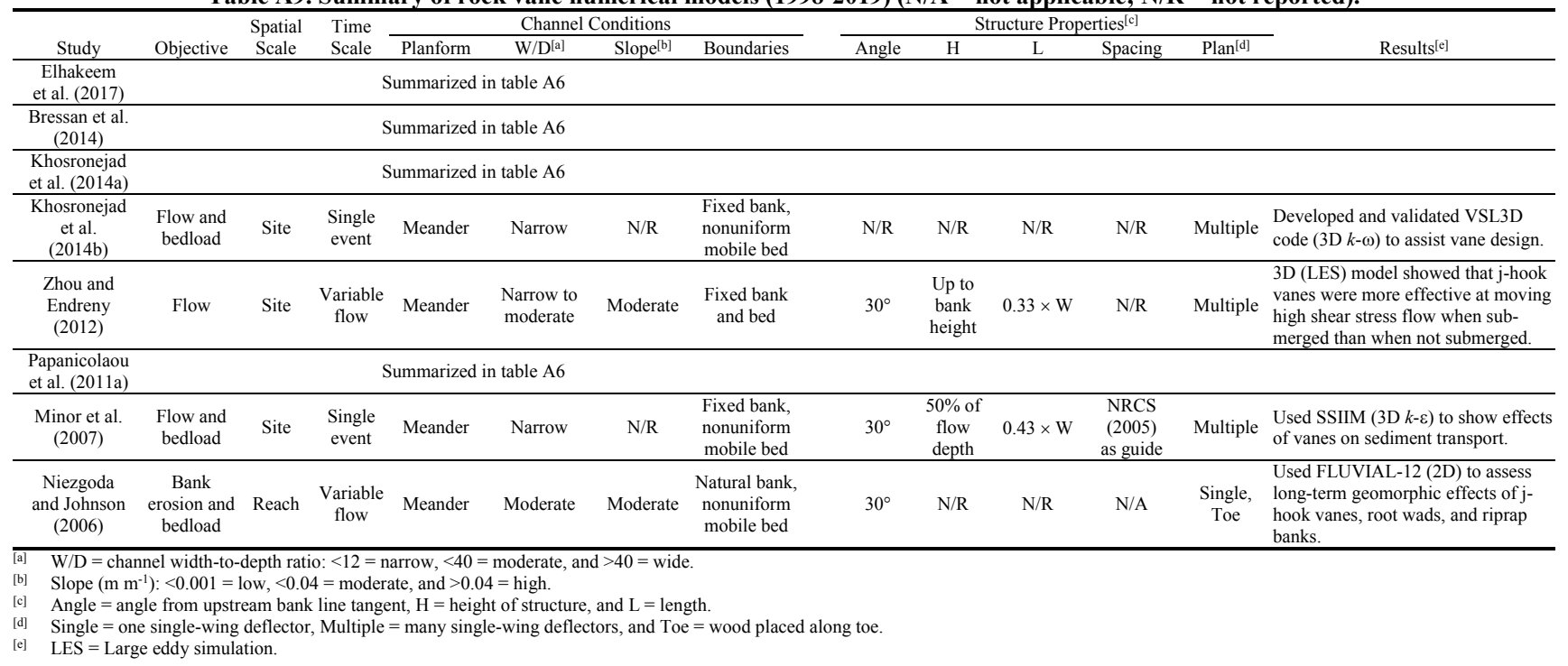


Table A10. Summary of permeable spur studies (1998-2019) $(\mathrm{N} / \mathrm{R}=$ not reported).

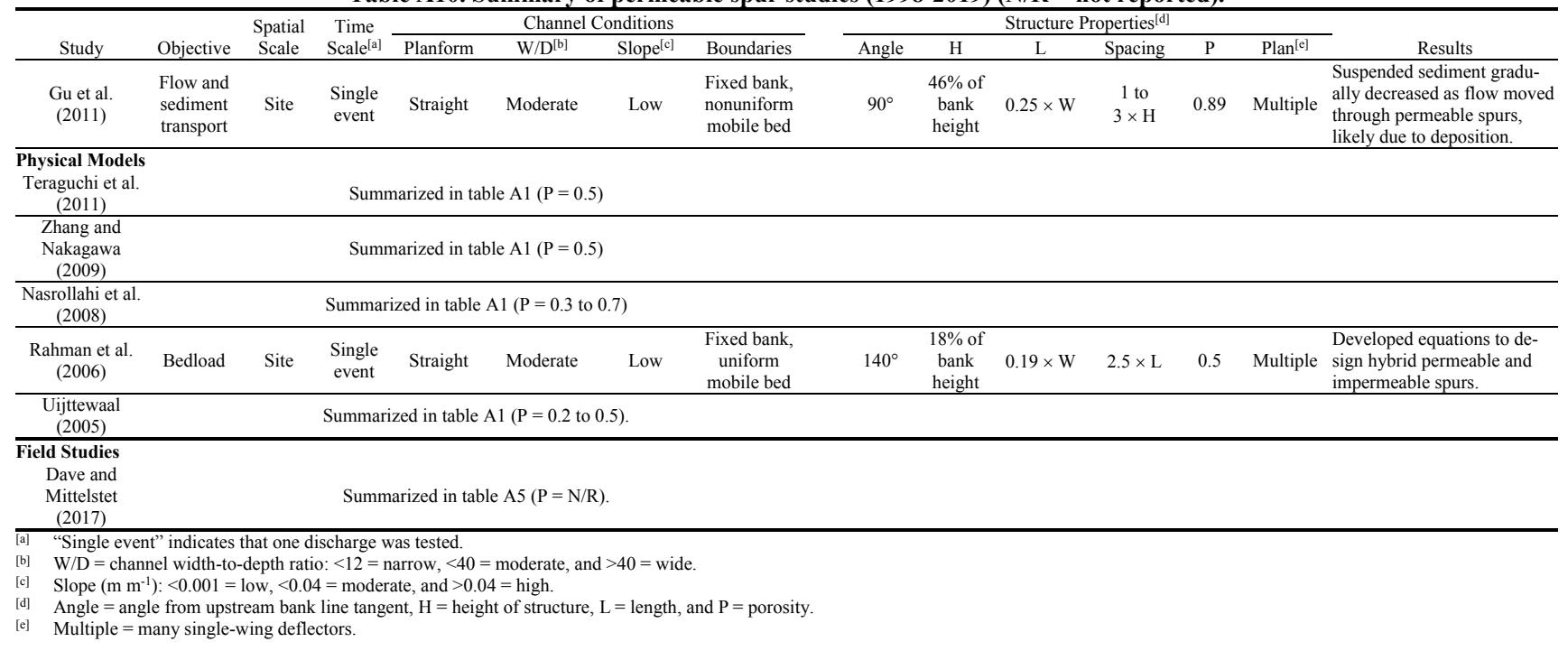

Table A11. Summary of submerged vane physical models (1998-2019) $(\mathrm{N} / \mathrm{A}=$ not applicable; $\mathrm{N} / \mathrm{R}=$ not reported).

\begin{tabular}{|c|c|c|c|c|c|c|c|c|c|c|c|c|c|}
\hline \multirow[b]{2}{*}{ Study } & \multirow[b]{2}{*}{ Objective } & \multirow{2}{*}{$\begin{array}{c}\text { Spatial } \\
\text { Scale }\end{array}$} & \multirow{2}{*}{$\begin{array}{c}\text { Time } \\
\text { Scale }^{[a]}\end{array}$} & \multicolumn{4}{|c|}{ Channel Conditions } & \multicolumn{5}{|c|}{ Structure Properties ${ }^{[\mathrm{d}]}$} & \multirow[b]{2}{*}{ Results } \\
\hline & & & & Planform & $\mathrm{W} / \mathrm{D}^{[\mathrm{b}]}$ & Slope $^{[c]}$ & Boundaries & Angle & $\mathrm{H}$ & $\mathrm{L}$ & Spacing & Plan $^{[\mathrm{e}]}$ & \\
\hline $\begin{array}{l}\text { Dey et al. } \\
\text { (2017) }\end{array}$ & $\begin{array}{l}\text { Bank } \\
\text { erosion, } \\
\text { flow, and } \\
\text { bedload }\end{array}$ & Site & $\begin{array}{l}\text { Single } \\
\text { event }\end{array}$ & Meander & Narrow & $\mathrm{N} / \mathrm{R}$ & $\begin{array}{c}\text { Erodible } \\
\text { bank, } \\
\text { uniform } \\
\text { mobile bed }\end{array}$ & $\begin{array}{l}10^{\circ} \\
\text { to } 40^{\circ}\end{array}$ & $\begin{array}{l}20 \% \text { to } \\
40 \% \text { of } \\
\text { bank } \\
\text { height }\end{array}$ & $\begin{array}{l}2 \text { to } \\
3 \times \mathrm{H}\end{array}$ & $\begin{array}{l}10 \text { to } \\
30 \times \mathrm{H}\end{array}$ & Multiple & $\begin{array}{l}15^{\circ} \text { angle resulted in minimum bank } \\
\text { erosion and scour. }\end{array}$ \\
\hline $\begin{array}{l}\text { Gupta et al. } \\
\quad(2010)\end{array}$ & Bedload & Site & $\begin{array}{l}\text { Single } \\
\text { event }\end{array}$ & Straight & $N / R$ & $\mathrm{~N} / \mathrm{R}$ & $\begin{array}{l}\text { Fixed bank, } \\
\text { nonuniform } \\
\text { mobile bed }\end{array}$ & $40^{\circ}$ & $\begin{array}{c}25 \% \text { of } \\
\text { bank } \\
\text { height }\end{array}$ & $0.6 \times \mathrm{H}$ & N/A & Single & $\begin{array}{l}\text { Added a circular collar on leading } \\
\text { edge of vane to minimize scour and } \\
\text { dislodging; optimal angle was } 40^{\circ} \text {. }\end{array}$ \\
\hline $\begin{array}{l}\text { Tan et al. } \\
(2005)\end{array}$ & $\begin{array}{l}\text { Flow and } \\
\text { bedload }\end{array}$ & Site & $\begin{array}{l}\text { Single } \\
\text { event }\end{array}$ & Straight & Moderate & $\mathrm{N} / \mathrm{R}$ & $\begin{array}{l}\text { Fixed bank, } \\
\text { uniform } \\
\text { mobile bed }\end{array}$ & $\begin{array}{l}15^{\circ} \\
\text { to } 90^{\circ}\end{array}$ & $\begin{array}{c}\% \text { to } \\
25 \% \text { of } \\
\text { bank } \\
\text { height }\end{array}$ & $\begin{array}{l}0.16 \text { to } \\
0.66 \times \mathrm{W}\end{array}$ & N/A & Single & $\begin{array}{l}30^{\circ} \text { angle with a height } \geq 2 \times \text { to } 3 \times \text { the } \\
\text { existing bedform resulted in the } \\
\text { greatest scour. }\end{array}$ \\
\hline $\begin{array}{l}\text { Voisin and } \\
\text { Townsend } \\
(2002)\end{array}$ & $\begin{array}{l}\text { Bank } \\
\text { erosion and } \\
\text { bedload }\end{array}$ & Site & $\begin{array}{l}\text { Single } \\
\text { event }\end{array}$ & Meander & Narrow & Low & $\begin{array}{l}\text { Fixed bank, } \\
\text { nonuniform } \\
\text { mobile bed }\end{array}$ & $\begin{array}{l}-4^{\circ} \\
\text { to } 16^{\circ}\end{array}$ & $\begin{array}{l}10 \% \text { to } \\
43 \% \text { of } \\
\text { bank } \\
\text { height }\end{array}$ & $\begin{array}{l}0.16 \text { to } \\
0.49 \times \mathrm{W}\end{array}$ & $\begin{array}{l}0.33 \text { to } \\
1.31 \times \mathrm{W}\end{array}$ & Multiple & $\begin{array}{l}\text { Vane height and angle had the great- } \\
\text { est effects on scour and bank ero- } \\
\text { sion; optimal design was Angle }=2^{\circ} \text {, } \\
\mathrm{H}=0.23 \times \text { bank height, } \mathrm{L}=0.33 \times \\
\mathrm{W} \text {, and Spacing }=0.7 \times \mathrm{W} .\end{array}$ \\
\hline $\begin{array}{l}\text { Marelius and } \\
\text { Sinha (1998) }\end{array}$ & Flow & Site & $\begin{array}{l}\text { Single } \\
\text { event }\end{array}$ & Straight & Narrow & $\mathrm{N} / \mathrm{R}$ & $\begin{array}{l}\text { Fixed bank, } \\
\text { uniform } \\
\text { mobile bed }\end{array}$ & $\begin{array}{l}25^{\circ} \\
\text { to } 57^{\circ}\end{array}$ & $\begin{array}{l}30 \% \text { of } \\
\text { flow } \\
\text { depth }\end{array}$ & $2 \times \mathrm{H}$ & N/A & Single & $\begin{array}{l}40^{\circ} \text { angle vane produced strongest } \\
\text { secondary circulation in flow field; } \\
\text { undermining needed to be addressed. }\end{array}$ \\
\hline
\end{tabular}

"Sisce event" indicates that one discharge was tested.

[b] $\mathrm{W} / \mathrm{D}=$ channel width-to-depth ratio: $<12=$ narrow,$<40=$ moderate, and $>40=$ wide.

[c] Slope $\left(\mathrm{m} \mathrm{m}^{-1}\right):<0.001=$ low, $<0.04=$ moderate, and $>0.04=$ high.

[d] Angle $=$ angle from upstream bank line tangent, $\mathrm{H}=$ height of structure, and $\mathrm{L}=$ length.

[e] $\quad$ Single $=$ one submerged vane, and Multiple $=$ many submerged vanes.

Table A12. Summary of submerged vane numerical models (1998-2019) $(\mathrm{N} / \mathrm{A}=$ not applicable; $\mathrm{N} / \mathrm{R}=$ not reported).

\begin{tabular}{|c|c|c|c|c|c|c|c|c|c|c|c|c|c|}
\hline \multirow[b]{2}{*}{ Study } & \multirow[b]{2}{*}{ Objective } & \multirow{2}{*}{$\begin{array}{l}\text { Spatial } \\
\text { Scale }\end{array}$} & \multirow{2}{*}{$\begin{array}{l}\text { Time } \\
\text { Scale }\end{array}$} & \multicolumn{4}{|c|}{ Channel Conditions } & \multicolumn{5}{|c|}{ Structure Properties ${ }^{[c]}$} & \multirow[b]{2}{*}{ Results } \\
\hline & & & & Planform & $\mathrm{W} / \mathrm{D}^{[\mathrm{a}]}$ & Slope $^{[b]}$ & Boundaries & Angle & $\mathrm{H}$ & $\mathrm{L}$ & Spacing & $\operatorname{Plan}^{[\mathrm{d}]}$ & \\
\hline $\begin{array}{c}\text { Ouyang and } \\
\text { Lu (2016) }\end{array}$ & $\begin{array}{l}\text { Bank } \\
\text { erosion and } \\
\text { bedload }\end{array}$ & Site & $\begin{array}{l}\text { Single } \\
\text { event }\end{array}$ & Meander & Narrow & $\mathrm{N} / \mathrm{R}$ & $\begin{array}{l}\text { Fixed bank, } \\
\text { nonuniform } \\
\text { mobile bed }\end{array}$ & $\begin{array}{l}10^{\circ} \\
\text { to } 25^{\circ}\end{array}$ & $\begin{array}{l}50 \% \text { of } \\
\text { flow } \\
\text { depth }\end{array}$ & $\begin{array}{l}\text { Avg. } \\
\text { flow } \\
\text { depth }\end{array}$ & Varied & Array & $\begin{array}{l}\text { Used a 1D model to develop a proce- } \\
\text { dure to optimize vane spacing for } \\
\text { bank protection; depended on radius } \\
\text { of curvature and channel width. }\end{array}$ \\
\hline $\begin{array}{l}\text { Ouyang and } \\
\text { Lin (2016) }\end{array}$ & $\begin{array}{l}\text { Bank } \\
\text { erosion and } \\
\text { bedload }\end{array}$ & Site & $\begin{array}{l}\text { Single } \\
\text { event }\end{array}$ & Meander & Narrow & $\mathrm{N} / \mathrm{R}$ & $\begin{array}{l}\text { Fixed bank, } \\
\text { nonuniform } \\
\text { mobile bed }\end{array}$ & $\begin{array}{l}10^{\circ} \\
\text { to } 20^{\circ}\end{array}$ & $\begin{array}{l}80 \% \text { of } \\
\text { flow } \\
\text { depth }\end{array}$ & $\begin{array}{l}1.5 \times \text { avg } \\
\text { flow } \\
\text { depth }\end{array}$ & $\begin{array}{l}0.5 \text { to } \\
0.8 \times \text { avg. } \\
\text { flow } \\
\text { depth }\end{array}$ & $\begin{array}{l}\text { Multiple } \\
\text { arrays }\end{array}$ & $\begin{array}{l}\text { 1D model showed that tapered vanes } \\
\text { were more effective than rectangular } \\
\text { at inducing deposition; increasing } \\
\text { spacing decreased shape effect. }\end{array}$ \\
\hline $\begin{array}{l}\text { Sharma et al. } \\
\text { (2016) }\end{array}$ & Flow & Site & $\begin{array}{l}\text { Single } \\
\text { event }\end{array}$ & Straight & Narrow & Low & $\begin{array}{l}\text { Fixed bank } \\
\text { and bed }\end{array}$ & $\begin{array}{l}15^{\circ} \\
\text { to } 60^{\circ}\end{array}$ & $\begin{array}{l}20 \% \text { to } \\
60 \% \text { of } \\
\text { flow } \\
\text { depth }\end{array}$ & $\begin{array}{c}0.05 \text { to } \\
0.12 \times \mathrm{W}\end{array}$ & $0.125 \times \mathrm{W}$ & $\begin{array}{l}\text { Multiple } \\
\text { arrays }\end{array}$ & $\begin{array}{l}3 \mathrm{D}(\mathrm{k}-\omega) \text { model showed vane angle } \\
\text { of } 30^{\circ} \text { and height of } 0.4 \times \text { flow depth } \\
\text { maximized turbulence in vane field. }\end{array}$ \\
\hline $\begin{array}{c}\text { Ouyang } \\
(2009)\end{array}$ & $\begin{array}{l}\text { Bank } \\
\text { erosion and } \\
\text { bedload }\end{array}$ & Site & $\begin{array}{l}\text { Single } \\
\text { event }\end{array}$ & Meander & Narrow & $\mathrm{N} / \mathrm{R}$ & $\begin{array}{l}\text { Fixed bank, } \\
\text { nonuniform } \\
\text { mobile bed }\end{array}$ & $<25^{\circ}$ & $\begin{array}{l}58 \% \text { to } \\
70 \% \text { of } \\
\text { flow } \\
\text { depth }\end{array}$ & $\begin{array}{l}0.5 \text { to } \\
1.5 \times \text { flow } \\
\text { depth }\end{array}$ & $\mathrm{N} / \mathrm{A}$ & Single & $\begin{array}{l}\text { Applied a 1D model to quantify ef- } \\
\text { fects vane shape (rectangular, ta- } \\
\text { pered, or swept) on deposition and } \\
\text { optimize design. }\end{array}$ \\
\hline $\begin{array}{l}\text { Ouyang et al. } \\
(2008)\end{array}$ & $\begin{array}{l}\text { Bank } \\
\text { erosion and } \\
\text { bedload }\end{array}$ & Site & $\begin{array}{l}\text { Single } \\
\text { event }\end{array}$ & Meander & Moderate & $\mathrm{N} / \mathrm{R}$ & $\begin{array}{l}\text { Fixed bank, } \\
\text { mobile bed }\end{array}$ & $\begin{array}{l}10^{\circ} \\
\text { to } 40^{\circ}\end{array}$ & $0.5 \times \mathrm{L}$ & $\begin{array}{l}\text { Flow } \\
\text { depth }\end{array}$ & $\begin{array}{c}0.6 \text { to } \\
1.5 \times \mathrm{L}\end{array}$ & Array & $\begin{array}{l}\text { 1D model showed that less deposi- } \\
\text { tion occurred in vane field when } \\
\text { spacing decreased, while additional } \\
\text { vanes in a row increased deposition. }\end{array}$ \\
\hline $\begin{array}{l}\text { Flokstra } \\
(2006)\end{array}$ & $\begin{array}{l}\text { Flow and } \\
\text { bedload }\end{array}$ & Site & $\begin{array}{l}\text { Single } \\
\text { event }\end{array}$ & Meander & Moderate & $\mathrm{N} / \mathrm{R}$ & $\begin{array}{l}\text { Fixed bank, } \\
\text { uniform } \\
\text { mobile bed }\end{array}$ & $15^{\circ}$ & $\begin{array}{c}17 \% \text { to } \\
33 \% \text { of } \\
\text { flow } \\
\text { depth }\end{array}$ & $0.08 \times W$ & $\begin{array}{l}0.66 \text { to } \\
1.33 \times \text { flow } \\
\text { depth }\end{array}$ & Multiple & $\begin{array}{l}\text { Delft3D-MOR model (2D) flow cal- } \\
\text { culations differed from those ob- } \\
\text { tained by other developers. }\end{array}$ \\
\hline $\begin{array}{l}\text { Sinha and } \\
\text { Marelius } \\
(2000)\end{array}$ & Bedload & Site & $\begin{array}{l}\text { Single } \\
\text { event }\end{array}$ & Straight & Narrow & $\mathrm{N} / \mathrm{R}$ & $\begin{array}{l}\text { Fixed bank, } \\
\text { uniform } \\
\text { mobile bed }\end{array}$ & $\begin{array}{l}10^{\circ} \\
\text { to } 30^{\circ}\end{array}$ & $\mathrm{N} / \mathrm{R}$ & $\mathrm{N} / \mathrm{R}$ & N/A & Single & $\begin{array}{l}\text { Developed and calibrated a 3D } \\
\text { model }(k-\varepsilon) \text { to quantify bedload ef- } \\
\text { fects of vanes. }\end{array}$ \\
\hline $\begin{array}{l}\mathrm{W} / \mathrm{D}=\mathrm{ch} \\
\text { Slope }(\mathrm{m}\end{array}$ & NIU & & & & & & & & & & & & \\
\hline $\begin{array}{l}\text { Angle }=\text { an } \\
\text { Array }=\text { rov }\end{array}$ & $\begin{array}{l}\text { from upstre } \\
\text { f submergee }\end{array}$ & eam ban & ne $\tan$ & H = hei & of structur & 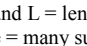 & conoed yon & Wltin & 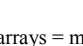 & 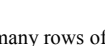 & 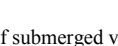 & 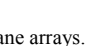 & \\
\hline
\end{tabular}


Table A13. Summary of woody revetment studies (1998-2019) (N/A = not applicable; N/R = not reported).

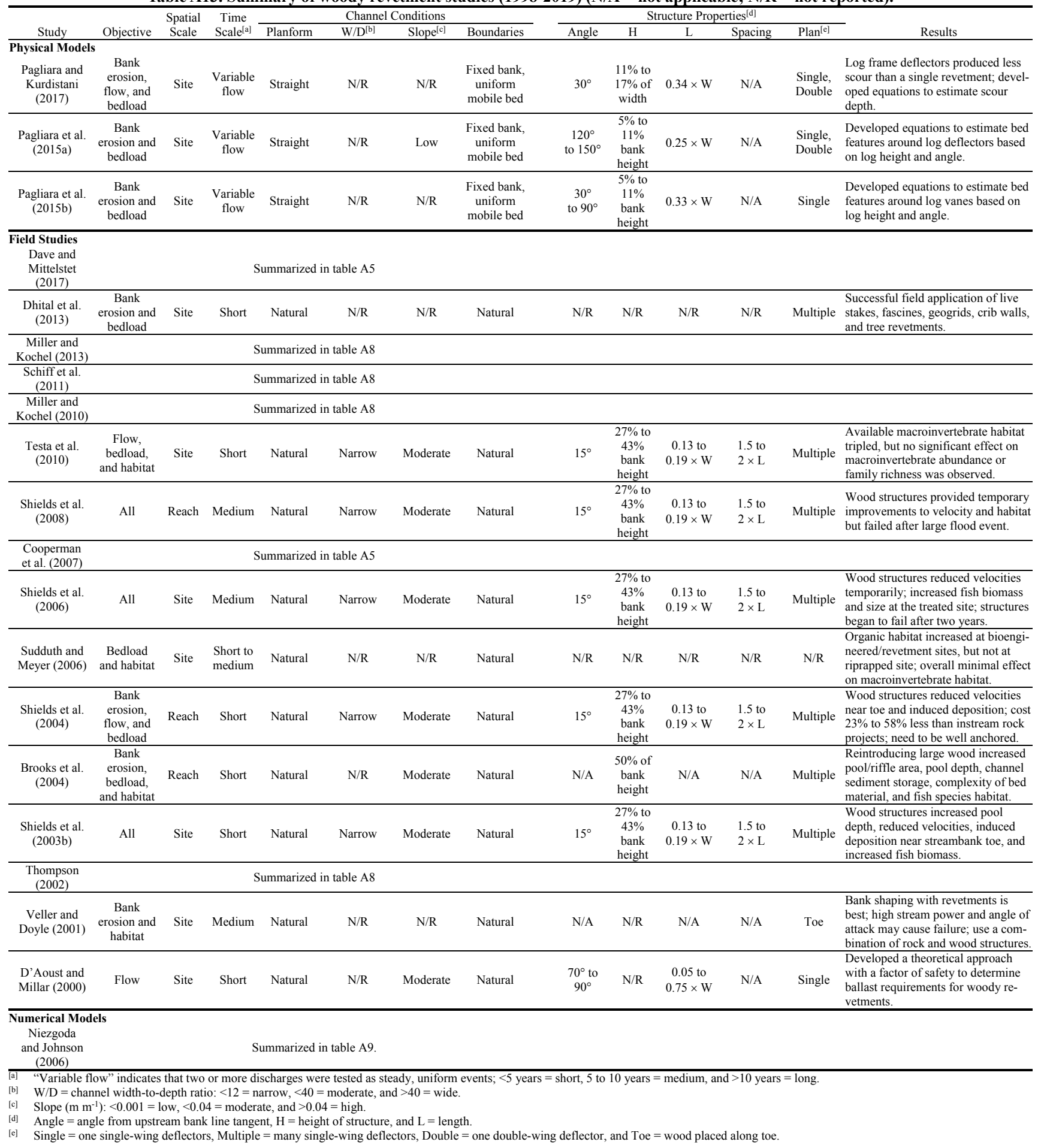


Table A14. Summary of hardened bank physical modeling studies (1998-2019) $(\mathrm{N} / \mathrm{R}=$ not reported).

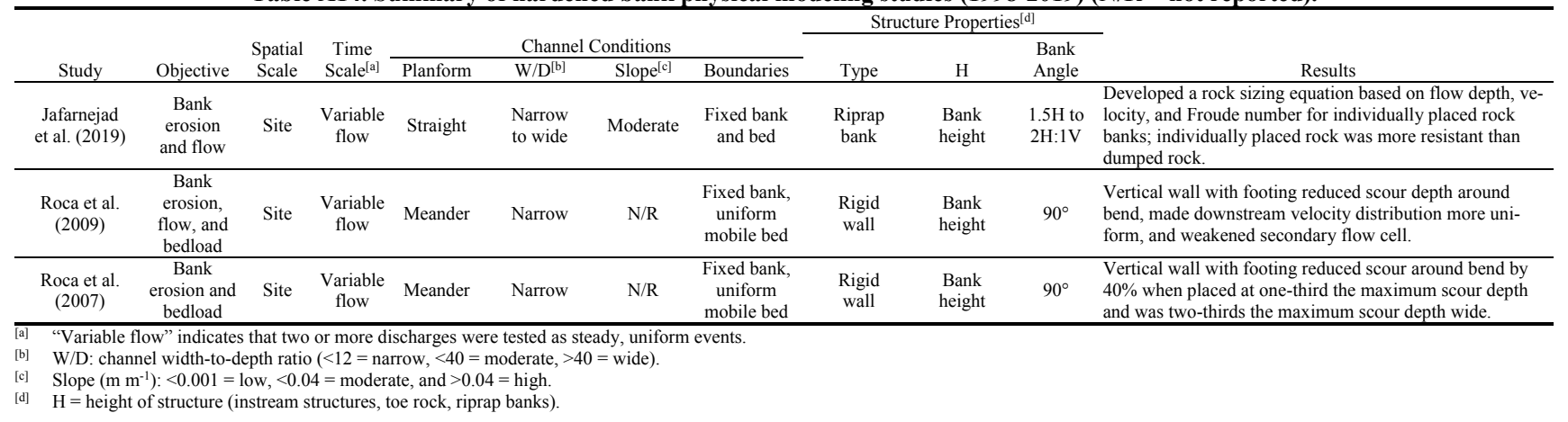

Table A15. Summary of hardened bank field studies (1998-2019) $(\mathrm{N} / \mathrm{R}=$ not reported).

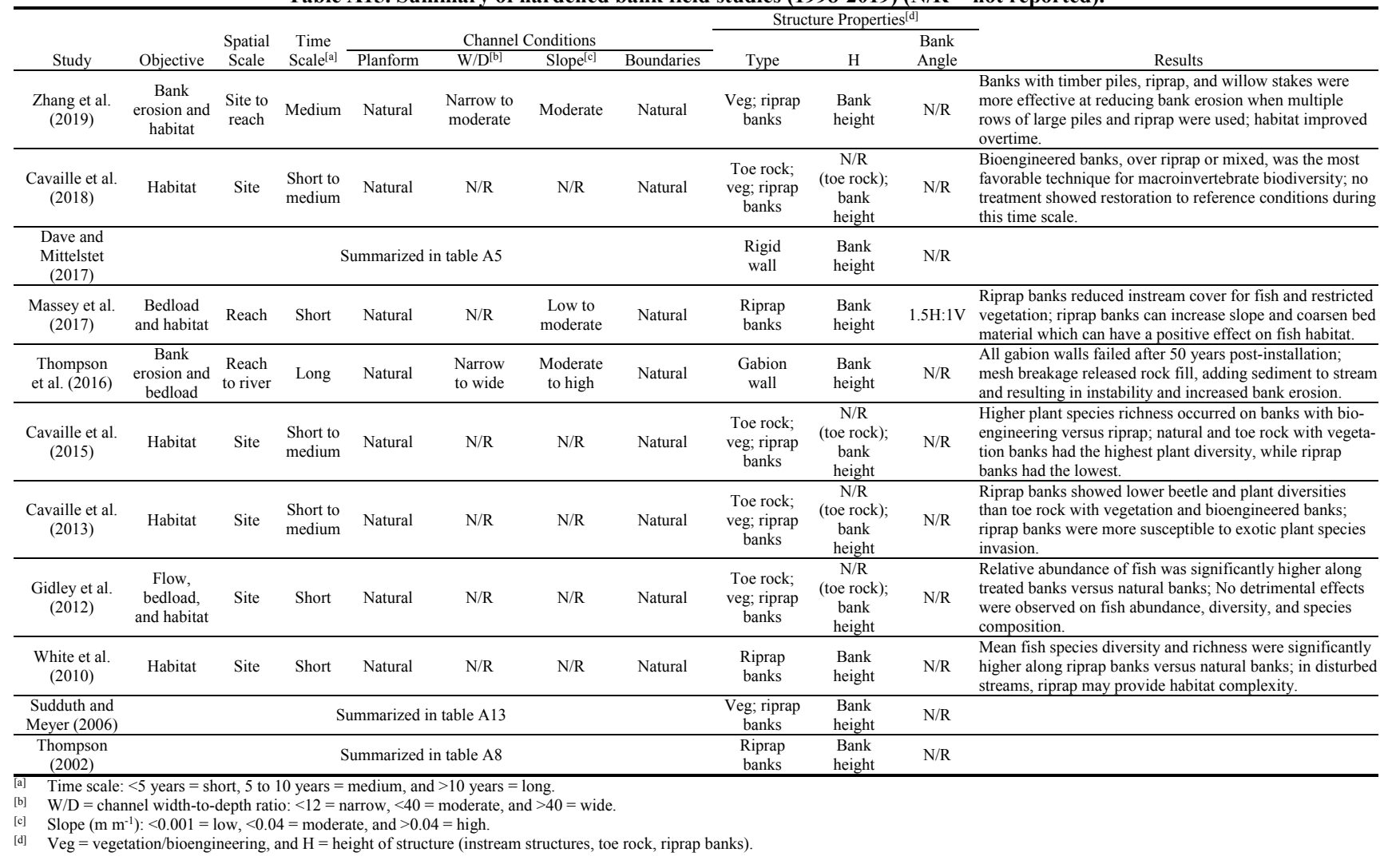

Table A16. Summary of hardened bank numerical modeling studies (1998-2019) ( $N / R=$ not reported).

\begin{tabular}{|c|c|c|c|c|c|c|c|c|c|c|c|}
\hline \multirow[b]{3}{*}{ Study } & \multirow[b]{3}{*}{ Objective } & \multirow{3}{*}{$\begin{array}{l}\text { Spatial } \\
\text { Scale }\end{array}$} & \multirow{3}{*}{$\begin{array}{l}\text { Time } \\
\text { Scale }\end{array}$} & \multirow{2}{*}{\multicolumn{4}{|c|}{ Channel Conditions }} & \multicolumn{3}{|c|}{ Structure Properties ${ }^{[\mathrm{c}]}$} & \multirow[b]{3}{*}{ Results } \\
\hline & & & & & & & & & & Bank & \\
\hline & & & & Planform & $\mathrm{W} / \mathrm{D}^{[\mathrm{a}]}$ & Slope ${ }^{[b]}$ & Boundaries & Type & $\mathrm{H}$ & Angle & \\
\hline $\begin{array}{l}\text { Jafarnejad } \\
\text { et al. (2017) }\end{array}$ & $\begin{array}{l}\text { Bank } \\
\text { erosion and } \\
\text { bedload }\end{array}$ & Site & $\begin{array}{l}\text { Variable } \\
\text { flow }\end{array}$ & Meander & $\mathrm{N} / \mathrm{R}$ & $\begin{array}{l}\text { Moderate } \\
\text { to high }\end{array}$ & $\begin{array}{l}\text { Fixed bank, } \\
\text { nonuniform } \\
\text { mobile bed }\end{array}$ & $\begin{array}{l}\text { Riprap } \\
\text { banks }\end{array}$ & $\begin{array}{l}\text { Bank } \\
\text { height }\end{array}$ & $1.8 \mathrm{H}: 1 \mathrm{~V}$ & $\begin{array}{l}\text { Developed a probabilistic assessment model to assess fail- } \\
\text { ure of riprap banks due to changes in flow and/or sediment } \\
\text { transport; toe scour often resulted in failure. }\end{array}$ \\
\hline $\begin{array}{c}\text { Reid and } \\
\text { Church (2015) }\end{array}$ & $\begin{array}{c}\text { Bank } \\
\text { erosion and } \\
\text { bedload }\end{array}$ & Reach & $\begin{array}{l}\text { Single } \\
\text { event }\end{array}$ & Meander & $\mathrm{N} / \mathrm{R}$ & $\mathrm{N} / \mathrm{R}$ & $\begin{array}{l}\text { Fixed bank, } \\
\text { nonuniform } \\
\text { mobile bed }\end{array}$ & $\begin{array}{l}\text { Riprap } \\
\text { banks }\end{array}$ & $\begin{array}{l}\text { Bank } \\
\text { height }\end{array}$ & $\mathrm{N} / \mathrm{R}$ & $\begin{array}{l}\text { 1D model showed that riprap banks stopped sediment sup- } \\
\text { ply from bank erosion, resulting in bed scour and coarsen- } \\
\text { ing at site. }\end{array}$ \\
\hline $\begin{array}{l}\text { Bressan et al. } \\
(2014)\end{array}$ & \multicolumn{7}{|c|}{ Summarized in table A6 } & $\begin{array}{l}\text { Riprap } \\
\text { banks }\end{array}$ & $\begin{array}{r}\text { Bank } \\
\text { height }\end{array}$ & $1.5 \mathrm{H}: 1 \mathrm{~V}$ & \\
\hline $\begin{array}{l}\text { Froehlich } \\
\text { (2013) }\end{array}$ & $\begin{array}{l}\text { Bank } \\
\text { erosion }\end{array}$ & Site & $\begin{array}{l}\text { Variable } \\
\text { flow }\end{array}$ & Meander & $\begin{array}{l}\text { Narrow to } \\
\text { wide }\end{array}$ & $\begin{array}{l}\text { Low to } \\
\text { moderate }\end{array}$ & $\begin{array}{l}\text { Fixed bank, } \\
\text { fixed bed }\end{array}$ & $\begin{array}{l}\text { Riprap } \\
\text { banks }\end{array}$ & $\begin{array}{l}\text { Bank } \\
\text { height }\end{array}$ & $\begin{array}{l}1.3 \mathrm{H} \text { to } \\
3 \mathrm{H}: 1 \mathrm{~V}\end{array}$ & $\begin{array}{l}\text { Developed rock sizing equation for riprap banks composed } \\
\text { of loose rock based on factor of safety; provided accurate } \\
\text { estimates of real-world success and failure. }\end{array}$ \\
\hline $\begin{array}{l}\text { Jorgensen } \\
\text { et al. (2013) }\end{array}$ & $\begin{array}{c}\text { Flow and } \\
\text { habitat }\end{array}$ & River & $\begin{array}{l}\text { Variable } \\
\text { flow }\end{array}$ & Meander & $\mathrm{N} / \mathrm{R}$ & $\mathrm{N} / \mathrm{R}$ & $\mathrm{N} / \mathrm{R}$ & $\begin{array}{l}\text { Riprap } \\
\text { banks }\end{array}$ & $\begin{array}{l}\text { Bank } \\
\text { height }\end{array}$ & $1.5 \mathrm{H}: 1 \mathrm{~V}$ & $\begin{array}{l}\text { Climate and hydrologic model (1D) showed that shallow } \\
\text { water habitat for salmon would decrease due to riprap } \\
\text { placement and climate change. }\end{array}$ \\
\hline $\begin{array}{c}\text { Niezgoda and } \\
\text { Johnson (2006) } \\
\end{array}$ & \multicolumn{7}{|c|}{ Summarized in table A8 } & $\begin{array}{c}\text { Riprap } \\
\text { banks }\end{array}$ & $\begin{array}{r}\text { Bank } \\
\text { height }\end{array}$ & $\mathrm{N} / \mathrm{R}$ & \\
\hline $\begin{array}{c}\text { Larsen and } \\
\text { Greco (2002) }\end{array}$ & $\begin{array}{l}\text { Bank } \\
\text { erosion and } \\
\text { bedload }\end{array}$ & Reach & $\begin{array}{l}\text { Single } \\
\text { event }\end{array}$ & Meander & Wide & Low & $\begin{array}{l}\text { Natural bank, } \\
\text { nonuniform } \\
\text { mobile bed }\end{array}$ & $\begin{array}{l}\text { Riprap } \\
\text { banks }\end{array}$ & $\begin{array}{l}\text { Bank } \\
\text { height }\end{array}$ & $\mathrm{N} / \mathrm{R}$ & $\begin{array}{l}\text { Channel migration model (1D) showed that stabilization af- } \\
\text { fects planform; riprap caused more erosion downstream } \\
\text { than without riprap; channel realignment was the best op- } \\
\text { tion for the site. }\end{array}$ \\
\hline $\mathrm{W} / \mathrm{D}=\mathrm{cha}$ & & & & & & & & & & & \\
\hline
\end{tabular}


Table A17. Summary of soft streambank management studies (1998-2019), including toe rock, bank shaping, bankfull bench, and vegetation/ bioengineering (N/A = not applicable; $N / R=$ not reported).

\begin{tabular}{|c|c|c|c|c|c|c|c|c|c|c|c|}
\hline \multirow[b]{3}{*}{ Study } & \multirow[b]{3}{*}{ Objective } & \multirow{3}{*}{$\begin{array}{l}\text { Spatial } \\
\text { Scale }\end{array}$} & \multirow{3}{*}{$\begin{array}{c}\text { Time } \\
\text { Scale }^{[a]}\end{array}$} & \multirow{2}{*}{\multicolumn{4}{|c|}{ Channel Conditions }} & \multicolumn{3}{|c|}{ Structure Properties ${ }^{[\mathrm{d}]}$} & \multirow[b]{3}{*}{ Results } \\
\hline & & & & & & & & & & Bank & \\
\hline & & & & Planform & $\mathrm{W} / \mathrm{D}^{[\mathrm{b}]}$ & Slope $\mathrm{e}^{[\mathrm{c}]}$ & Boundaries & Type & $\mathrm{H}$ & Angle & \\
\hline \multicolumn{12}{|c|}{ Physical Models } \\
\hline $\begin{array}{l}\text { Recking et al. } \\
\text { (2019) }\end{array}$ & $\begin{array}{l}\text { Bank } \\
\text { erosion, } \\
\text { flow, and } \\
\text { bedload }\end{array}$ & Site & $\begin{array}{l}\text { Variable } \\
\text { flow }\end{array}$ & Meander & $\mathrm{N} / \mathrm{R}$ & Moderate & $\begin{array}{l}\text { Erodible } \\
\text { bank, } \\
\text { nonuniform } \\
\text { mobile bed }\end{array}$ & $\begin{array}{l}\text { Toe rock; } \\
\text { veg; shaping }\end{array}$ & $\mathrm{N} / \mathrm{R}$ & $\mathrm{N} / \mathrm{R}$ & $\begin{array}{l}\text { Structure failure due to water recirculation behind fascines } \\
\text { caused scour and erosion; structure worked better on large } \\
\text { radius of curvature meander with cohesive soils and toe } \\
\text { protection (toe rock or live stakes). }\end{array}$ \\
\hline \multicolumn{12}{|l|}{ Field Studies } \\
\hline $\begin{array}{l}\text { Holmes et al. } \\
\text { (2019) }\end{array}$ & $\begin{array}{l}\text { Bedload } \\
\text { and habitat }\end{array}$ & $\begin{array}{l}\text { Site to } \\
\text { reach }\end{array}$ & Short & Natural & $\mathrm{N} / \mathrm{R}$ & $\mathrm{N} / \mathrm{R}$ & Natural & Shaping & N/A & $2 \mathrm{H}: 1 \mathrm{~V}$ & $\begin{array}{l}\text { Bank shaping caused a temporary }(<1 \text { year) increase in fine } \\
\text { sediment in bed at site, temporarily shifting predators to un- } \\
\text { treated sites and shifting prey populations to treated sites. }\end{array}$ \\
\hline $\begin{array}{c}\text { Zhang et al. } \\
(2019)\end{array}$ & \multicolumn{11}{|c|}{ Summarized in table A15 } \\
\hline $\begin{array}{c}\text { Cavaille et al. } \\
(2018)\end{array}$ & \multicolumn{11}{|c|}{ Summarized in table A15 } \\
\hline $\begin{array}{c}\text { Cavaille et al. } \\
(2015)\end{array}$ & \multicolumn{11}{|c|}{ Summarized in table A15 } \\
\hline $\begin{array}{l}\text { Krymer and } \\
\text { Robert (2014) }\end{array}$ & $\begin{array}{l}\text { Bank } \\
\text { erosion, } \\
\text { flow, and } \\
\text { bedload }\end{array}$ & Site & Long & Natural & $\begin{array}{l}\text { Narrow to } \\
\text { moderate }\end{array}$ & Moderate & Natural & Veg & $\begin{array}{l}\text { Bankfull } \\
\text { height }\end{array}$ & N/A & $\begin{array}{l}\text { Crib wall and site characteristics were all involved in long- } \\
\text { term stability; crib walls worked best with dense live cut- } \\
\text { tings in cohesive banks on stable streams, as opposed to de- } \\
\text { graded streams. }\end{array}$ \\
\hline $\begin{array}{l}\text { Cavaille et al. } \\
\text { (2013) }\end{array}$ & \multicolumn{11}{|c|}{ Summarized in table A15 } \\
\hline $\begin{array}{c}\text { Dhital et al. } \\
(2013)\end{array}$ & \multicolumn{11}{|c|}{ Summarized in table A13 } \\
\hline $\begin{array}{c}\text { Acharya and } \\
\text { Gautam (2012) }\end{array}$ & \multicolumn{7}{|c|}{ Summarized in table A2 } & Toe rock & $\mathrm{N} / \mathrm{R}$ & N/A & \\
\hline $\begin{array}{l}\text { Anstead et al. } \\
\quad(2012)\end{array}$ & $\begin{array}{l}\text { Bank } \\
\text { erosion }\end{array}$ & Site & Short & Natural & $\begin{array}{l}\text { Narrow to } \\
\text { moderate }\end{array}$ & Moderate & Natural & Veg & N/A & N/A & $\begin{array}{l}\text { Willow spiling may need maintenance in early years to } \\
\text { guarantee long-term bank stability; gravel banks require } \\
\text { deeper plantings; do not install on incising streams. }\end{array}$ \\
\hline $\begin{array}{c}\text { Gidley et al. } \\
(2012)\end{array}$ & \multicolumn{11}{|c|}{ Summarized in table A15 } \\
\hline $\begin{array}{c}\text { Schiff et al. } \\
(2011)\end{array}$ & \multicolumn{7}{|c|}{ Summarized in table A8 } & Veg & N/A & N/A & \\
\hline $\begin{array}{l}\text { Anstead and } \\
\text { Boar (2010) }\end{array}$ & $\begin{array}{l}\text { Bank } \\
\text { erosion }\end{array}$ & Site & Long & Natural & $\mathrm{N} / \mathrm{R}$ & $\mathrm{N} / \mathrm{R}$ & Natural & Veg & N/A & N/A & $\begin{array}{l}\text { Willow spiling projects were most successful when (1) de- } \\
\text { signed and placed strategically for optimal willow survival } \\
\text { and minimal undercutting and (2) continuously monitored } \\
\text { and maintained. }\end{array}$ \\
\hline $\begin{array}{l}\text { Petrone } \\
\text { and Preti } \\
(2008)\end{array}$ & $\begin{array}{l}\text { Bank } \\
\text { erosion }\end{array}$ & Site & Short & Natural & $\mathrm{N} / \mathrm{R}$ & $\mathrm{N} / \mathrm{R}$ & Natural & Veg & N/A & N/A & $\begin{array}{l}\text { Determined four native species that were most cost-effec- } \\
\text { tive for reducing bank erosion in Nicaragua. }\end{array}$ \\
\hline $\begin{array}{l}\text { Cooperman } \\
\text { et al. }(2007)\end{array}$ & \multicolumn{7}{|c|}{ Summarized in table A5 } & $\begin{array}{c}\text { Toe rock; } \\
\text { veg; shaping }\end{array}$ & $\mathrm{N} / \mathrm{R}$ & $\mathrm{N} / \mathrm{R}$ & \\
\hline $\begin{array}{l}\text { Pezeshki et al. } \\
\quad \text { (2007) }\end{array}$ & $\begin{array}{c}\text { Bank } \\
\text { erosion and } \\
\text { habitat }\end{array}$ & Site & Short & Natural & Narrow & Moderate & Natural & Veg & N/A & N/A & $\begin{array}{l}\text { Black willow plantings were more likely to survive at } \\
\text { lower elevations along a bank; survival increased along } \\
\text { silty banks versus banks with finer or coarser materials. }\end{array}$ \\
\hline $\begin{array}{l}\text { Li et al. } \\
(2006)\end{array}$ & $\begin{array}{l}\text { Bank } \\
\text { erosion and } \\
\text { habitat }\end{array}$ & Site & Short & Natural & $\mathrm{N} / \mathrm{R}$ & $N / R$ & Natural & Veg & N/A & $\mathrm{N} / \mathrm{A}$ & $\begin{array}{l}\text { Bioengineering reduced bank erosion, increased species } \\
\text { and habitat diversity, and improved water quality and aes- } \\
\text { thetics ten months post-installation, at a fraction of the cost } \\
\text { of other engineering approaches. }\end{array}$ \\
\hline $\begin{array}{c}\text { Sudduth and } \\
\text { Meyer (2006) }\end{array}$ & \multicolumn{11}{|c|}{ Summarized in tables A13 and A15 } \\
\hline $\begin{array}{c}\text { Veller and } \\
\text { Doyle (2001) }\end{array}$ & \multicolumn{7}{|c|}{ Summarized in table A13 } & Veg; shaping & N/A & $\begin{array}{l}2 \mathrm{H}: 1 \mathrm{~V} \\
(\max .)\end{array}$ & \\
\hline $\begin{array}{l}\text { Shields et al. } \\
\quad(2000)\end{array}$ & \multicolumn{7}{|c|}{ Summarized in table A5 } & $\begin{array}{l}\text { Toe rock; } \\
\text { veg }\end{array}$ & $\begin{array}{l}3,000 \text { to } \\
6,000 \\
\mathrm{~kg} \mathrm{~m}^{-1}\end{array}$ & N/A & \\
\hline $\begin{array}{l}\text { Simon and } \\
\text { Steineman } \\
(2000)\end{array}$ & $\begin{array}{l}\text { Bank } \\
\text { erosion }\end{array}$ & Site & $\begin{array}{l}\text { Short to } \\
\text { medium }\end{array}$ & Natural & $\mathrm{N} / \mathrm{R}$ & $\mathrm{N} / \mathrm{R}$ & Natural & $\begin{array}{l}\text { Toe rock; } \\
\text { veg; shaping }\end{array}$ & $\begin{array}{l}33 \% \text { of } \\
\text { bank } \\
\text { height }\end{array}$ & $2 \mathrm{H}: 1 \mathrm{~V}$ & $\begin{array}{l}\text { Identified five challenges with bioengineering, toe rock, } \\
\text { and shaping: (1) lack of before-treatment data, (2) short- } \\
\text { term vulnerability of project, (3) bad past projects, (4) lim- } \\
\text { ited site access, and (5) community involvement. }\end{array}$ \\
\hline $\begin{array}{l}\text { Shields et al. } \\
\text { (1998a) }\end{array}$ & \multicolumn{7}{|c|}{ Summarized in table A5 } & Toe rock & $\begin{array}{c}3,000 \text { to } \\
6,000 \\
\mathrm{~kg} \mathrm{~m}^{-1}\end{array}$ & $\mathrm{~N} / \mathrm{A}$ & \\
\hline $\begin{array}{c}\text { Shields et al. } \\
(1998 b)\end{array}$ & \multicolumn{7}{|c|}{ Summarized in table A5 } & $\begin{array}{l}\text { Toe rock; } \\
\text { veg }\end{array}$ & $\mathrm{N} / \mathrm{R}$ & N/A & \\
\hline \multicolumn{12}{|c|}{ Numerical Models } \\
\hline $\begin{array}{l}\text { Enlow et al. } \\
\text { (2018) }\end{array}$ & $\begin{array}{c}\text { Bank } \\
\text { erosion }\end{array}$ & Reach & $\begin{array}{c}\text { Single } \\
\text { event }\end{array}$ & Meander & $\mathrm{N} / \mathrm{R}$ & $\mathrm{N} / \mathrm{R}$ & Natural bank & $\begin{array}{l}\text { Toe rock; } \\
\text { veg; shaping }\end{array}$ & $\mathrm{N} / \mathrm{R}$ & $\begin{array}{l}2 \mathrm{H} \text { to } \\
3 \mathrm{H}: 1 \mathrm{~V}\end{array}$ & $\begin{array}{l}\text { CONCEPTS application (1D) found that } 2 \mathrm{H}: 1 \mathrm{~V} \text { slope with } \\
\text { vegetation was the most cost-effective streambank stabili- } \\
\text { zation technique for the stream of interest. }\end{array}$ \\
\hline $\begin{array}{l}\text { Elhakeem et al. } \\
\text { (2017) }\end{array}$ & \multicolumn{7}{|c|}{ Summarized in table A6 } & Toe rock & $\begin{array}{c}\text { two-year } \\
\text { RI }\end{array}$ & N/A & \\
\hline $\begin{array}{l}\text { Bischetti et al. } \\
(2010)\end{array}$ & $\begin{array}{c}\text { Bank } \\
\text { erosion }\end{array}$ & Site & N/A & N/A & N/A & N/A & $\begin{array}{c}\text { Cohesive } \\
\text { bank }\end{array}$ & Veg; shaping & N/A & $2 \mathrm{H}: 1 \mathrm{~V}$ & $\begin{array}{l}\text { Improved slope stability model (1D) to include effects of } \\
\text { fascines and bank shaping. }\end{array}$ \\
\hline $\begin{array}{l}\text { Simon et al. } \\
\text { (2009) }\end{array}$ & $\begin{array}{l}\text { Bank } \\
\text { erosion }\end{array}$ & Site & $\begin{array}{l}\text { Variable } \\
\text { flow }\end{array}$ & Meander & $\mathrm{N} / \mathrm{R}$ & $\mathrm{N} / \mathrm{R}$ & $\begin{array}{l}\text { Natural bank, } \\
\text { fixed bed }\end{array}$ & $\begin{array}{l}\text { Toe rock; } \\
\text { veg }\end{array}$ & $\begin{array}{l}7 \% \text { to } \\
76 \% \text { of } \\
\text { bank } \\
\text { height }\end{array}$ & $\mathrm{N} / \mathrm{A}$ & $\begin{array}{l}\text { B-STEM application (1D) showed that installation of toe } \\
\text { rock resulted in } 69 \% \text { to } 100 \% \text { reduction in bank erosion on } \\
\text { streams upstream of Lake Tahoe; planting of vegetation } \\
\text { also reduced bank erosion rates. }\end{array}$ \\
\hline $\begin{array}{l}\text { Frothingham } \\
\quad(2008)\end{array}$ & $\begin{array}{c}\text { Bank } \\
\text { erosion } \\
\text { and flow }\end{array}$ & Site & $\begin{array}{l}\text { Variable } \\
\text { flow }\end{array}$ & Meander & $\begin{array}{l}\text { Narrow to } \\
\text { moderate }\end{array}$ & $\mathrm{N} / \mathrm{R}$ & $\begin{array}{l}\text { Fixed bank, } \\
\text { fixed bed }\end{array}$ & $\begin{array}{c}\text { Toe rock; } \\
\text { veg; shaping }\end{array}$ & $\mathrm{N} / \mathrm{R}$ & $2 \mathrm{H}: 1 \mathrm{~V}$ & $\begin{array}{l}\text { Used stability threshold analysis (1D model) of velocity } \\
\text { and shear stress to determine that vegetation and toe rock } \\
\text { were the best design for a particular stream. }\end{array}$ \\
\hline $\begin{array}{l}\text { "Single ever } \\
<5 \text { years }=\mathrm{s}\end{array}$ & $\begin{array}{l}\text { nt" indicates th } \\
\text { short, } 5 \text { to } 10 y\end{array}$ & $\begin{array}{l}\text { hat one d } \\
\text { years }=\mathrm{m}\end{array}$ & $\begin{array}{l}\text { lischarge } \mathrm{w} \\
\text { tedium, an }\end{array}$ & $\begin{array}{l}\text { as tested, an } \\
d>10 \text { years }=\end{array}$ & $\begin{array}{l}\text { "Variable flo } \\
\text { long. }\end{array}$ & w" indicate & hat two or mo & e discharges & e tested & eady, $\mathrm{c}$ & form events; \\
\hline $\mathrm{W} / \mathrm{D}=$ chan & anel width-to-c & depth rati & io: $<12=\mathrm{n}$ & arrow, $<40=$ & moderate, and & $1>40=$ wid & & & & & \\
\hline Slope $\left(\mathrm{m} \mathrm{m}^{-}\right.$ & $-1):<0.001=1$ & ow, $<0.0$ & $4=$ moder & ate, and $>0.0$ & $4=$ high. & & & & & & \\
\hline
\end{tabular}

